\title{
Earth's rotation variations and earthquakes 2010-2011
}

\section{Ostřihanský}

Nad Palatou 7, 15000 Prague 5 - Smíchov, Czech Republic

Received: 6 November 2011 - Accepted: 13 November 2011 - Published: 19 January 2012

Correspondence to: L. Ostrihanský (ostrih @ tiscali.cz)

Published by Copernicus Publications on behalf of the European Geosciences Union.

Earth's rotation variations and earthquakes 2010-2011

L. Ostřihanský

\section{Title Page}

\section{Abstract}

Conclusions

Tables

14

4

Back

Full Screen / Esc

Printer-friendly Version

Interactive Discussion 


\section{Abstract}

In contrast to unsuccessful searching (lasting over 150 years) for correlation of earthquakes with biweekly tides, the author found correlation of earthquakes with sidereal 13.66 days Earth's rotation variations expressed as length of a day (LOD) measured 5 daily by International Earth's Rotation Service. After short mention about earthquakes M 8.8 Denali Fault Alaska 3 November 2002 triggered on LOD maximum and M 9.1 Great Sumatra earthquake 26 December 2004 triggered on LOD minimum and the full Moon, the main object of this paper are earthquakes of period 2010-June 2011: M 7.0 Haiti (12 January 2010 on LOD minimum, M8.8 Maule Chile 12 February 2010 on LOD maximum, map constructed on the Indian plate revealing 6 earthquakes from 7 on LOD minimum in Sumatra and Andaman Sea region, M 7.1 New Zealand Christchurch 9 September 2010 on LOD minimum and M6.3 Christchurch 21 February 2011 on LOD maximum, and M 9.1 Japan near coast of Honshu 11 March 2011 on LOD minimum. It was found that LOD minimums coincide with full or new Moon only twice in 15 a year in solstices. To prove that determined coincidences of earthquakes and LOD extremes stated above are not accidental events, histograms were constructed of earthquake occurrences and their position on LOD graph deeply in the past, in some cases from the time the IERS (International Earth's Rotation Service) started to measure the Earth's rotation variations in 1962. Evaluations of histograms and the Schuster's test have proven that majority of earthquakes are triggered in both Earth's rotation deceleration and acceleration. Because during these coincidences evident movements of lithosphere occur, among others measured by GPS, it is concluded that Earth's rotation variations effectively contribute to the lithospheric plates movement. Retrospective overview of past earthquakes revealed that the Great Sumatra earthquake 26 December 2004 had its equivalent in the shape of LOD graph, full Moon position, and character of aftershocks 19 years earlier in difference only one day to 27 December 1985 earthquake, proving that not only sidereal 13.66 days variations but also that the 19 years Metons cycle is the period of the earthquakes occurrence. Histograms show the

\section{Earth's rotation variations and earthquakes 2010-2011}

L. Ostřihanský

Title Page

Abstract

Conclusions

Tables

14

$<$

Back

Full Screen / Esc

Printer-friendly Version

Interactive Discussion 
regular change of earthquake positions on branches of LOD graph and also the shape of histogram and number of earthquakes on LOD branches from the mid-ocean ridge can show which side of the ridge moves quicker.

\section{Introduction}

5 Consideration of the Earth's rotation as a factor influencing the Earth's surface is based on very old data. Already Darwin (1881) recognized that owing to the Earth's rotation, the equatorial regions are subjected to greater forces than the polar regions. Böhm von Böhmersheim (1910) presented an opinion that the Earth's rotation and its changes is an energy source of orogenetic processes. Next I mention authors Veronnet (1927), Schmidt (1948) and Stovas (1957). The development of Earth's rotation theories begins after the confirmation of Earth's rotation variations by comparison with the atomic clock and later by exact measurements using baseline interferometry (Munk and MacDonald 1960). The detailed conception presented cites Chebanenko (1963), considering inertial forces acting on continents requiring, however, the slip of the Earth's

crust. Relation of the deep fault tectonics to rotation changes considers also MacDonald (1963). After confirmation of the continental drift by interpretation of linear magnetic anomalies and dating of oceanic basalts by Morley and Vine and Mathews (1963) and introduction of the plate tectonics principles, hypotheses occurred considering tidal forces as driving agents of the plate movements (Bostrom, 1971; Knopoff and Leeds, 1972; Moore, 1973). These hypotheses were rejected by estimation of the mantle viscosity by Cathles (1975), and Jordan (1975) presented a simple calculation that the mantle viscosity should be 10 orders of magnitude lower to make possible the movement, and most of geophysicists preferred the mantle convection as the plate driving agent originated in Holmes (1939) and later in McKenzie and Weiss (1975) and

others. Later, Ranalli (2000) supported such hypotheses refusing the rotational drag as driving agent. Then 20 years ago at XX. General Assembly of the International Union of Geodesy and Geophysics in Vienna 1991, the author (Ostřihanský, 1991) presented

SED

4, 33-130, 2012

Earth's rotation variations and earthquakes 2010-2011

L. Ostřihanský

Title Page

Abstract Introduction

Conclusions

References

Tables

Figures

14

$\Delta$

4

Back

Close

Full Screen / Esc

Printer-friendly Version

Interactive Discussion 
a hypothesis that Earth's rotation variations trigger earthquakes and introduce lithospheric plates into movement. In the monograph "The causes of lithospheric plates movements" (Ostriihanský, 1997), the hypothesis was elaborated in detail. The two largest earthquakes of this century, the large M 8.9 Denali Fault Alaska earthquake in

52002 and the M9.1 Great Sumatra earthquake in 2004, confirmed this hypothesis. It has been shown that plates moving westward move mostly in Earth's rotation deceleration and plates moving northward move in Earth's rotation acceleration (Ostrihanský, 2004); however, the following earthquake at Sumatra 28 March 2005 contradicted this concept. In the meantime, extensive investigation in global tectonic earthquakes have

10 shown evidence of a correlation with diurnal tides (Tanaka et al., 2002; Cochran et al., 2004). The Sumatra 26 December 2004 earthquake was triggered not only on exact winter Earth's rotation maximum speed but also on the full Moon. This inspired Crocket et al. (2006) to present a hypothesis of earthquake correlation with biweekly tides. This hypothesis was strictly refused by Cochran and Vidale (2007), presenting histograms 15 of global data. Supporters of the Earth's rotation effect are also Doglioni et al. (2007), showing that geological and geophysical asymmetries of rifts and subduction zones are a function of their polarity and may be interpreted as controlled by some astronomical mechanical shear (Scoppola et al., 2006). Crespi et al. ( 2007) have shown that plates follow a westward mainstream but incline to equator $\pm 7^{\circ}$.

\section{Earth's rotation variations, syzygy and hardly explainable coincidences with earthquakes}

Variations of the Earth's rotation are caused by the effects of Moon and Sun deforming the Earth's shape and by this way the Earth's angular polar moment of inertia leading to the change of its rotation velocity according the law of angular momentum conservation (Wahr, 1988). The Earth's rotation velocity is measured daily by IERS (International Earth's Rotation Service) (Figs. 1-4), expressed as the length of a day (LOD) in seconds. The LOD is therefore dependent on Moon and Sun configuration, on

\section{SED}

4, 33-130, 2012

Earth's rotation

variations and

earthquakes

2010-2011

L. Ostřihanský

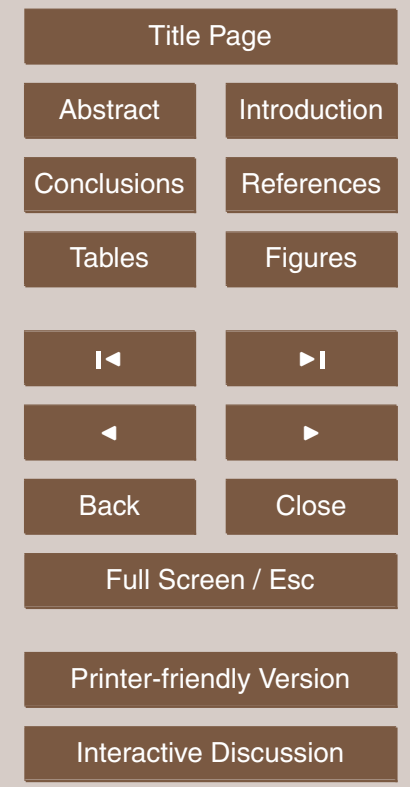


position of these bodies to the equator, which part of the Earth's surface these bodies pass over oceans and continents during their apparent daily movement, in less extent on atmospheric effects, however more distinctly on El Nino or La Nina effects (Rosen et al., 1984; Ostřihanský, 2004). The time span from the Moon's crossing the equator 5 to another equatorial crossing during its apparent movement takes 13.66 days. However, the corresponding Earth's decelerations can be different, depending on whether the Moon crosses the equator from Southern (mostly oceanic) to Northern Hemisphere (larger deceleration), or from Northern Hemisphere to Southern Hemisphere (smaller deceleration). The Sun causes semiannual variations: On the LOD graph there are 0 winter and summer accelerations. More distinct is the summer acceleration (shifted to the late summer in July), caused by the heating of the Northern (mostly continental) Hemisphere and corresponding volume expansion in summer (Kalenda et al., 2010). Meteorological effect and atmospheric super rotation (e.g., Hide, 1984) can be also considered.

15 As introduction to this paragraph, I strictly mention the Denali Fault and Sumatra earthquakes, which initiated my investigation. The Denali Fault Alaska earthquake is an arc shaped rupture and its central part is roughly sub parallel to latitudes. It reflects the boundary between the slow westward movement of the American plate in higher latitudes and quicker NW movement of the Pacific plate. Therefore, it is sensitive to deceleration of the Earth's rotation and accordingly the M 8.9 earthquake of 3 November 2002 was triggered during the Earth's rotation deceleration (Fig. 1) (Ostřihanský, 2010) in LOD maximum. Because the earthquake was triggered on the third LOD maximum peak, the resonance effect is considered as an earthquake increasing factor.

For the next investigation I chose the group of earthquakes on faults subparallel with 25 longitudes. The investigated rectangle $\left(14^{\circ} \mathrm{N}-5^{\circ} \mathrm{S}, 105-90^{\circ} \mathrm{E}\right.$ of earthquakes taken from USGS NEIC and ANSS Catalog) was chosen on the west side of continental lithosphere on the Eurasian plate to avoid westward pressures. These earthquakes cover the subduction zone of the Sumatra and Andaman Sea. Northward pressures triggered earthquakes at the time of Earth's rotation acceleration on Sumatra 26 December 2004,

\section{SED}

4, 33-130, 2012

Earth's rotation variations and earthquakes 2010-2011

L. Ostřihanský

Title Page

Abstract Introduction

Conclusions

References

Tables

Figures

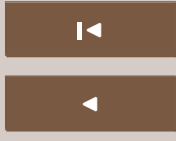

$\Delta$

Back

Close

Full Screen / Esc

Printer-friendly Version

Interactive Discussion 
M 9.1 (Fig. 2). Repeating Earth's rotation accelerations (LOD minimums) triggered this huge earthquake and tsunamis. According to coincidence with LOD minimum, the Sumatra earthquake 26 December 2004 was triggered exactly at the time of the full Moon (Fig. 3b), which evoked hypotheses about biweekly tides triggering (Crockett 5 et al., 2006).

This study should be distinguished from studies dealing with semidiurnal or biweekly tidal triggering of earthquakes, which for more than 150 years (first attempts are described in Varga and Denis (2010) and over the Schuster's test (Schuster, 1911) present mostly negative results. These attempts are based on comparison of tidal 10 semidiurnal phase between high and low tide to earthquakes. Studies of Cochran et al. (2004) and Tanaka et al. (2002) are considered as positive. Quite negative are studies of biweekly tides ranging from syzygy in rhythm 14.7 days of lunar synodic time-scale (Weems and Perry, 1989).

Decisive for the earthquakes triggering are 13.66 days frequencies of sidereal lunar 15 scale, which reflect the Earth's deformation in rhythm of Moon's declination variation. Variations of Earth's rotation caused by Moon are $\sim 1.5 \mathrm{~ms}$ and by Sun $\sim 3 \mathrm{~ms}$ in late summer, but in longer 182.6 days period. Rotation variations sufficiently shake the Earth and this knocking effect moves lithospheric plates in hard medium of viscous mantle $10^{19} \mathrm{~Pa}$ only two orders of magnitude less viscous than lithosphere $10^{21} \mathrm{Pas}$. Variations of the Earth's rotation are not negligible if $1 \mathrm{~ms}=0.015^{\prime \prime}=46 \mathrm{~cm}$ shift on equator. A $1.5 \mathrm{~ms}$ variation shakes the Earth $69 \mathrm{~cm}$ in east-west direction. A hypothetical image is offered where deeply rooted continental lithosphere by this periodic knocking is released and like a pneumatic pick it moves through the mantle by external forces, considered up to now owing to high mantle viscosity as insufficient for the 25 movement.

Let us perform a simple calculation to compare biweekly tides with Earth's rotation variations. Substituting the exact sidereal semiperiod of Moon's orbit $t_{1}=$ 13.66008305 days and synodial syzygy of the Moon's full or new semiperiod $t_{2}=$ 14.765294 days, the coincidence $s=t_{1} \cdot t_{2} / t_{2}-t_{1}=182.63$ days. Therefore, the
SED

4, 33-130, 2012

Earth's rotation variations and earthquakes 2010-2011

L. Ostřihanský

Title Page

Abstract Introduction

Conclusions

References

Tables

Figures

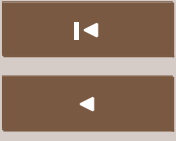

$>1$

Back

Close

Full Screen / Esc

Printer-friendly Version

Interactive Discussion 
coincidence occurs twice in the year and always at the time of winter or summer solstices. The stable coincidence of LOD minimum with the full or new Moon in solstices is an interesting phenomenon. The explanation is the following: The LOD minimum means that the Moon has the highest declination. The full or new Moon means that 5 Moon, Earth and Sun are on the same line and this means that at that moment the Moon exerts the largest torque on the Earth's axis. For this reason the coincidence of full or new Moon with LOD minimum occur always in winter or summer solstices. However, from this logically follows that also the full or new Moon has to coincide with LOD maximums in equinoxes. Solstices and equinoxes are therefore the time of the 10 largest earthquake activity. In addition, the close frequencies of sidereal and synodial periods create beats. Table 1 presents results of 17 earthquakes with magnitudes over M 5.8, which occurred at solstice time from 49 earthquakes triggered in the LOD minimums in chosen rectangle covering the Sumatra and Andaman Sea from 1963 to 2011 with a total 264 earthquakes. The strongest of them, the M9.1 Sumatra earthquake 15 of 26 December 2004 (Fig. 3b), already mentioned in Fig. 2, and the next strongest the Sumatra earthquake of 27 December 1985 (M 6.6) were triggered exactly 19 years apart. Fig. 3c shows this important repetition. Comparison of Figs. $3 b$ and $3 c$ shows striking similarity of both earthquakes in maximums and aftershocks. LOD minimums and the full Moons differ only one day: 26 December 2004 and 27 December 1985, respectively. It is not due to chance the similarity of these two dates during the 19 years time span because the Metonic cycle governs the earthquake triggering. The Metonic cycle is a period of very close to 19 years, which is remarkable for being very nearly a common multiple of solar year and the synodic month. The Greek astronomer Meton of Athens observed that a period of 19 years is almost exactly equal to 235 synodic months, and rounded to full days counts 6940 days. No wonder that the earthquakes of 26 December 2004 and 27 December 1985 coincide not only in the LOD minimum but also on the full Moon. This configuration represents the greatest torque acting on the Earth trying to rectify the Earth's bulging to the plane of ecliptic or the Moon's orbit. The lunisolar torque acting on the Earth trying to rectify the Earth's bulging to the plane
SED

4, 33-130, 2012

\section{Earth's rotation variations and earthquakes 2010-2011}

L. Ostřihanský

Title Page

Abstract Introduction

Conclusions

References

Tables

Figures

14

$\rightarrow 1$

4

Back

$\checkmark$

Close

Full Screen / Esc

Printer-friendly Version

Interactive Discussion 
of ecliptic and the Moon's orbit is $1.210^{22} \mathrm{~N} \mathrm{~m}$ (Stacey 1977) and the torque caused by tidal bulging is only $5.110^{16} \mathrm{~N} \mathrm{~m}$ (Burša 1987). For this reason, the movement of plates northward is stronger than westward unless the continent-continent collision prevents the movement. However, decisive for the plate movement is the variable shaking of 5 the Earth by the Earth's rotation variation, reducing friction. The 19 years earthquake cycle is probably common in many sites of the Earth but it is not necessary to be so exact. In the mountain area of Alaska, the 19 year cycle is evident, however delayed for several months. The first Alaskan earthquake after the LOD measurement is the very strong earthquake in Prince William Sound, M 8.5, 28 March 1964 on the full Moon and exact position on the LOD maximum. The next strongest earthquake, M 6.4, occurred in Prince William Sound on 12 July 1983 with more than 3 months delay on the LOD summer minimum. The last strongest earthquake, M6.36, occurred in the $200 \mathrm{~km}$ distant Denali Fault on 23 October 2002, again more than 3 months delayed followed by already mentioned M 7.9 Denali Fault earthquake on 3 November 2002 situated exactly on the LOD maximum, evoked by resonance (Ostřihanský 2010).

Fig. $3 b$ and $3 c$ shows striking similarity of both earthquakes in maximums and aftershocks for Sumatra earthquakes. LOD minimums and full Moons differ for only one day (26 December 2004 and 27 December 1985) but there are some differences. In Fig. 3b there are several next minimums: 9 January 2005, 24 January 2005 and 5 February 20 2005. In Fig. 3c an earthquake is at minimum 20 February 1986 in Fig. 3b is missing. The earthquake 28 March 2005 occurred shortly after the vernal point and coincidence of earthquake with LOD maximum was expected. The coincidence occurred however with 2 days delay, repeating this delay twice in aftershocks (Fig. 3a). It coincides better with syzygy, typically 2 days after. An assumption is offered that tidal loading triggered 25 these earthquakes, contributing to the huge flooding after tsunami. However, except of coincidences summarized in Table 1, there are earthquakes not coinciding with LOD minimums on solstices. Fig. $3 d$ presents such a case. There are 2 earthquakes coinciding with LOD maximums 9 December 2009 and 23 December 09 and also with neap tides, i.e. they coincide with the first and last Moon's quarter. An assumption is
SED

4, 33-130, 2012

\section{Earth's rotation variations and earthquakes 2010-2011}

L. Ostřihanský

Title Page

Abstract Introduction

Conclusions

References

Tables

Figures

14

- I

4

Back

$\checkmark$

Close

Full Screen / Esc

Printer-friendly Version

Interactive Discussion 
offered that earthquakes are triggered not only in increased pressures but also in the release of pressures. LOD maximum indicates the reverse of pressures relatively to LOD minimum.

\section{Characteristics of 2010-2011 earthquakes}

5 In contrast to the LOD record from 2009 with mostly symmetric 13.66 days variations, for the whole 2010 year the record is typical, characterized by asymmetric LOD maximums after every 27.32 days corresponding to the Earth's decelerations. This triggered some disastrous earthquakes (Figs. 4 and 5), which besides these also included some disastrous earthquakes in winter and summer minimums.

10 Variations of the Earth's rotation coincide with earthquakes, offering strong evidence that just Earth's rotation variations can facilitate the lithospheric plates movement over the mantle.

\subsection{7.0 Haiti region 12 January 2010}

Identifying the time of magnitude 7.0 Haiti region earthquake on 12 January 2010 with LOD record, it can be seen that this earthquake corresponds to the quickest Earth's rotation, owing to the maximum Moon's declination, deforming the Earth in direction to poles, and resulting in a decrease of the polar mass momentum of inertia and the increment of rotation speed in LOD winter minimum (Fig. 4a). The Haiti earthquake occurred (Fig. 4e) on the east-west directing transform fault with left-lateral strike slip faulting on the northern side of the Caribbean plate (Enriquillo-Plantain Garden fault system) (USGS Poster, 2010). This transform fault therefore expresses the quicker westward movement of the North American plate than the Caribbean plate and probably also than the whole South American plate. No wonder that just during the increment of Earth's rotation velocity (minimum of LOD curve) the earthquake occurred.

\section{SED}

4, 33-130, 2012

Earth's rotation variations and earthquakes 2010-2011

L. Ostřihanský
Abstract

Conclusions

Tables

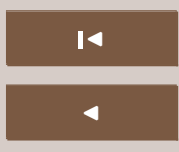

Back
Title Page

Introduction

References

Figures

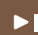

Close

Full Screen / Esc

Printer-friendly Version

Interactive Discussion 
The quicker movement of the Northern Hemisphere is also evident from the westward shift of the Mid-Atlantic ridge in the North Atlantic Ocean, whereas in the South Atlantic Ocean the Mid-Atlantic ridge keeps its original meridional direction. A smaller opening of the Atlantic Ocean in the Northern Hemisphere shows that also the Eurasian 5 plate moves westward (Fig. 4b).

A more detailed explanation of the Haiti earthquake origin compares earthquakes in Enriquillo-Plantain Garden transform fault with earthquakes on Mid-Atlantic Ridge, which are in close relation (Fig. 4c, d). Variations of the Earth's rotation by their accelerations and decelerations open the Mid-Atlantic Ridge and trigger shallow earthquakes

10 in rhythm of inflection points of LOD record. It is not chance that, consequently from equator to higher latitudes, earthquakes were triggered from the end of December 2009 , to as far as an earthquake had occurred at the most western site of the MidAtlantic Ridge on 8 January 2010 (Fig. 4b, d), where the pressure reached maximum. The westward drift of the American plate, enlarged by the resonance effect of four LOD 15 minimums (Fig. 4c left), caused distinctive westward shift of the Northern Hemisphere and triggered the Haiti earthquake on the transform fault at the northern side of the Caribbean plate.

\subsection{8.8 Offshore Maule Chile 27 February 2010}

Increasing LOD amplitudes at the end of January 2010 are displayed by an increased 20 occurrence of earthquakes in the Mid-Atlantic Ridge. After 28 days, the largest LOD peak (i.e. the Earth's deceleration) is in coincidence with triggering earthquake M 8.8 Offshore Maule Chile 27 February 2010 (Fig. 4f). This was the 56th earthquake that occurred in 3 days interval before maximum from 349 earthquakes $>M 6$ during the 1973-2011 period. The earthquake occurred three days before the maximum length 25 of a day, i.e. with the slowest Earth rotation of the first half of that year. The Moon at that time was situated over the equator during its apparent movement. The Earth had been deformed, which enlarged its equatorial size and evoked an increment of the polar mass momentum of inertia and the Earth's rotation deceleration. The enlarged

SED

4, 33-130, 2012

\section{Earth's rotation variations and earthquakes 2010-2011}

L. Ostřihanský

Title Page

Abstract Introduction

Conclusions

Tables

References

Figures

14

4

Back

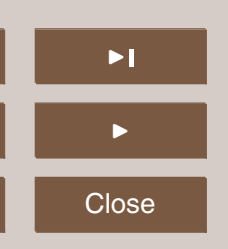

Full Screen / Esc

Printer-friendly Version

Interactive Discussion 
bulging of oceans caused an increment of the westward drag of the lithosphere. Let us also mention the extremely high tides off the Argentina coast: Rio Gallegos $29 \mathrm{~m}$. The fundamental important confirmation of the plate movement was the GPS measurement performed before and after the earthquake, showing an exceptional westward 5 displacement near the epicenter, entering the city of Concepcion $3.04 \mathrm{~m}$. The most exciting news was that the whole continent of South Central Chile and Argentina had displaced itself westward in Buenos Aires $2-4 \mathrm{~cm}$ as far north as the Chilean border with Peru (Fig. 6). This important discovery was performed by international US, Chilean and Argentinean research groups led by the head of CAP (Central and Southern Andes 10 GPS Project) Mike Bevis (SOEST News 2010). This GPS measurement confirmed the quick westward movement of the continental and oceanic part of the South American plate shown before (Ostrihanský 1997) by the movement and opening of the Scotia Sea back-arc basin. This is final proof that the South American plate overrides the oceanic lithosphere of the Nazca plate, which is static or moves very slowly over the asthenosphere. GPS measurements performed later over a larger part of the southern region of the South American continent (Madariaga et al., 2010) showed that the GPS movements follow exactly the westward direction.

In Fig. 4a the record of earthquakes shows that earthquakes (mostly aftershocks of the Maule Chile) remained at rest after May 2010 till the end of year. Only two earthquakes occurred over 6th magnitude: The earthquake M 7.1 Ecuador 12 August 2010 (depth $106 \mathrm{~km}$ ) and the earthquake M 6.2 in vicinity of Maule Chile (50 km south) at depth $16 \mathrm{~km}$ on 9 September 2010. Both of these earthquakes coincide exactly with maximums of LOD record corresponding to the Earth's rotation deceleration and the westward movement of the whole South American plate in the same way as the Maule

Chile earthquake confirmed.

Most of the earthquakes in the Chile Trench, as shown by the earthquake M8.8 Maule Chile, are preceded by an earthquake on Mid Atlantic Ridge (black bars Fig. 4f). However, at the beginning of 2011 a change occurred: The earthquake M 7.1 Araucania 2 January 2011 occurred at LOD minimum followed by earthquakes in the
SED

4, 33-130, 2012

\section{Earth's rotation variations and earthquakes 2010-2011}

L. Ostřihanský

Title Page

Abstract Introduction

Conclusions

References

Tables

Figures

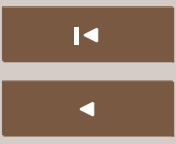

- I

Back

Close

Full Screen / Esc

Printer-friendly Version

Interactive Discussion 
Mid-Atlantic Ridge. Similarly, the earthquakes M6.8 Biobio Chile 11 January 2011 and M6.6 Offshore Maule Chile 14 February 2011 preceded the earthquake in the MidAtlantic Ridge (Fig. 4g). This is a very important change of earthquake occurrence and their relation to LOD polarity, which needs an explanation. Mid-ocean ridge reacts

5 first on Earth's variations; however, after the continent overthrust the subduction zone is released by melted magma and the reverse process occurs. The subduction zone reacts first on Earth's variation at that moment of LOD minimum. Earthquakes in subduction zone occur first and then in the mid-ocean ridge. Therefore, the initial positive LOD earthquake is changed in reciprocal cycles after 7 days, triggering earthquakes in 10 the subducton zone in LOD minimum (Fig. 4g). The last mentioned earthquakes occurred in the second LOD minimum. The next LOD second minimum occurred exactly after 27.32 days on 11 March 2011, exerting a crucial effect on the Honshu earthquake (described in detail in paragraph 3.4).

\subsection{Earthquakes in the Indian plate}

15 Several strong earthquakes also occurred in 2010 on the Indian plate (Fig. 4h). Similarly as in the Sumatra earthquake of 26 December 2004, most of earthquakes were triggered on the LOD minimum. The most striking case is the Moro Gulf Philippines earthquake 27 July 2010 , exactly corresponding to the summer LOD minimum. Other earthquakes also correspond to the LOD minimums: M6.6 Northern Sumatra 5 May 20 2010, M6.1 N. Guinea 26 November 2010, M 7.7 Kapulauan Mentawai 25 October 2010, most of the earthquakes from Papua (M7.7 on 4 August 2010, M 6.0 on 28 September 2010), and M7.0 New Zealand 3 September 2010. Out from minimum or maximum LOD are earthquakes from Vanuatu (N. Hebrides). This is a collision of two oceanic lithospheres: the oceanic Pacific plate and the oceanic part of the Indian 25 plate, which act against each other and from which the earthquake triggering is indefinite. Exact coincidence with LOD minimum is M6.7 Salomon Island 26 June 2010, whereas other earthquakes from this area from the beginning of the year are out of coincidence. The earthquake M 7.2 Northern Sumatra 9 May 2010 was 7 days delayed

\section{Earth's rotation variations and earthquakes 2010-2011}

L. Ostřihanský

Title Page

Abstract Introduction

Conclusions

References

Tables

Figures

14

4

Back

Close

Full Screen / Esc

Printer-friendly Version

Interactive Discussion 
and situated on smaller LOD maximum. The same was true for the earthquake of 28 March 2005, which was 10 days delayed. Similarly, the earthquake of 9 May 2010 preceded the strong $\sim 1.38 \mathrm{~ms}$ velocity increment (Fig. 3a1 Attachment). Conclusion: If an earthquake precedes the strong rotation deceleration (compression) and then quick acceleration, such earthquakes are mostly delayed in LOD minimum.

The earthquake M 7.1 Christchurch 3 September 2010 occurred on the second LOD minimum, as did most of the earthquakes in the Indian plate in autumn 2010 (Fig. 4h) (Fig. 4i). However, the disastrous earthquake M6.3 Christchurch 21 February 2011 occurred in reciprocal cycles in LOD maximum (Fig. 4i).

10 To distinguish the movement of the Indian plate according to earthquakes triggered by the Earth's rotation variation to the north and to the west, a special graphic method was performed (Fig. 4j).

The Southeast Indian Ocean Ridge presents a very important proof of force acting on the plate. According to number of earthquakes in ascending and descending branches Of LOD record (Fig. 4m), we find that number of earthquakes on the descending branch of LOD record is 33 (blue bars), whereas on the ascending branch there are only 22 (orange bars). This result shows that there is a force acting during the Earth's acceleration, pushing the plate northward. Because the Eötvös force (Eötvös, 1913) is proportional to the Earth's rotation in second power, its action on the Indian plate is probable. It can be seen that this force acts on the descending branch of the LOD graph from May to July and also from October to December. Less frequent earthquakes are on the ascending branch from January to March and from September to November. Similar results for 2008 show 29 earthquakes on the descending branch and only 19 on the ascending one. However, in the years 2009 and 2007-2004, differences between earthquakes on the ascending and descending branches are less than \pm 5 earthquakes.

\section{SED}

4, 33-130, 2012

Earth's rotation variations and earthquakes 2010-2011

L. Ostřihanský

Title Page

Abstract Introduction

Conclusions

References

Tables

Figures

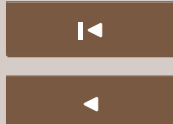

$\rightarrow 1$

$\checkmark$

Back

Close

Full Screen / Esc

Printer-friendly Version

Interactive Discussion 


\subsection{9.0 Near the coast of Honshu Japan 11 March 2011}

Studying the last strongest M9.0 earthquake near the coast of Honshu Japan on 11 March 2011, it was also found that this earthquake was triggered by the Earth's rotation variation. Surprising was its exact position on the second LOD minimum (Fig. 5a). The 5 second LOD minimum earthquakes are typical for many earthquakes in the second half of year in the Indian plate and also in the Chile Trench. The earthquake M 6.8 Biobio Chile 11 February 2011 occurred in the second LOD minimum, confirming the reverse mode of Earth's variation triggering when originally the LOD maximum triggering for the whole year 2010 was changed in the beginning of 2011 into the LOD minimum 10 triggering.

The cause of M9.0 near the coast of Honshu Japan 11 March 2011 earthquake is the following:

The accelerating Earth left behind on the west by inertia the Eurasian plate. For a better understanding, in accordance with GPS measurements, which considers the continental lithosphere as fixed with GPS satellite system, let us imagine that the rolling mantle beneath the continental lithosphere shifted the oceanic lithosphere of the Pacific plate eastward, separated it from the Japan Trench and shifted the Japan continent in Honshu 8 feet ( $2.44 \mathrm{~m}$ ) eastward (NASA 2011) (Fig. 5b) and caused the subsidence of oceanic lithosphere, which resulted in the huge tsunami. It is therefore possible to state the hypothesis that earthquakes triggered in subduction zones in LOD minimum can cause tsunami. This is in agreement with many earthquakes, including M 9.1 Sumatra 26 December 2004.

\section{SED}

4, 33-130, 2012

Earth's rotation variations and earthquakes 2010-2011

L. Ostřihanský

Title Page

Abstract Introduction

Conclusions

References

Tables

Figures

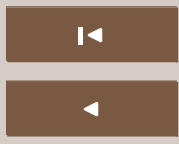

Back

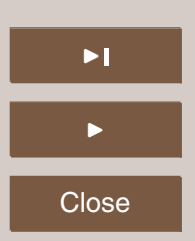

Full Screen / Esc

Printer-friendly Version

Interactive Discussion 


\section{Statistics and histograms evaluating acquired results}

It is possible to perform the Schuster's test (Schuster, 1897; Tanaka et al., 2002; Wilcock, 2009) for the histogram. The vector sum $D$ of phasors is defined

$D^{2}=\left(\sum_{i=1}^{N} \cos \phi_{i}\right)^{2}+\left(\sum_{i=1}^{N} \sin \phi_{i}\right)^{2}$

5 where $\phi_{i}$ is the phase angle of the $i$-th earthquake and $N$ is the total number of earthquakes included in the data set. When $\phi_{i}(i=1 \ldots N)$ distribute randomly, the probability $p$ that the length of a vectorial sum is equal or larger than $D$ is given by

$p=\exp \left(-\frac{D^{2}}{N}\right)$.

Thus, the $p$ value represents the significance level to reject the null hypothesis that earthquakes occur randomly irrespective of the phase angle. The $p$ value ranges between 0 and 1, and the smaller the $p$ value is, the higher the confidence in rejecting the null hypothesis is. Similarly, as do Tanaka et al. (2002), I tentatively adopt a threshold of $p<5 \%$ to judge a significant correlation between the Earth's variations and earthquake occurrence.

15 In the Schuster's test, the number of histogram intervals should be the number divisible by 4 , otherwise the phasor with $\cos \varphi$ does not give the same number of intervals above and below the $\varphi$ axis. For this reason the number of suitable intervals of 14 , which approximately reflects the 13.66 days sidereal period of the Earth's rotation variations, is necessary to reduce for 12 intervals by the linear interpolation. Because this is tedious work, I performed this for syzygy with a 14.77 days period and for the sidereal 13.66 period, investigating in both cases the earthquakes of Sumatra and Andaman Sea 1963-2011 (Table 2). Using a 14 days distribution, intervals $\varphi= \pm 90^{\circ}$ are omitted in $\cos \varphi$ phasor; however, in phasor with $\sin \varphi$ they are multiplied by \pm 1 , so that the

\section{Earth's rotation variations and earthquakes 2010-2011}

L. Ostřihanský

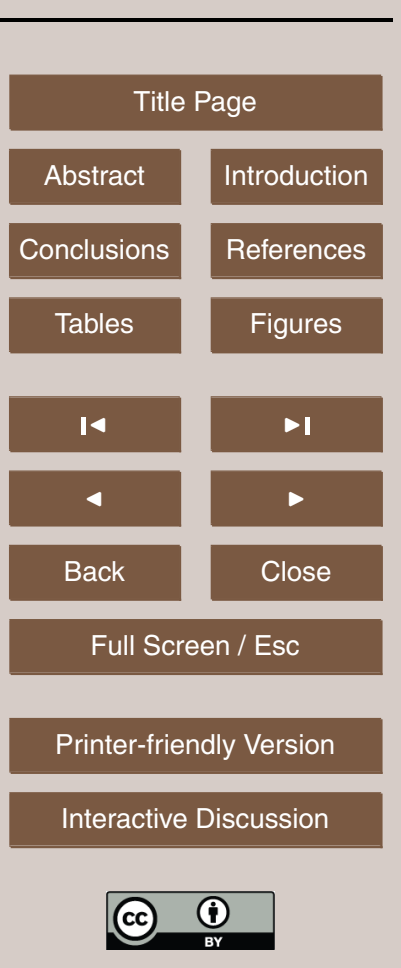


differences for 14 and 12 intervals are mostly insignificant (Table 2). The transfer from the phase angle $\varphi$ to coordinate $x$ of histogram interval is given in corresponding figure of histogram. The origin of counting days in the sidereal LOD cycle can be performed from inflexion point on the ascending LOD branch or back from inflexion point on the 5 descending branch (e.g. Fig. 7c). This procedure brings certain uncertainties because the LOD curve is not a theoretical curve with a constant number of days; the ascending or descending branches contain 6,7 and 9 points with the most probable being 7 day points. This results in decrease of count in the LOD maximums or minimums and the increase of count before these points (Fig. 7c). A better way is therefore to contribute 10 to minimum and maximum the fixed number, e.g. 7 and 14, and to count earthquakes back and forward from these points. To perform linear interpolation and to divide every branch for constant 7 points would mean that intervals in maximums and minimums of histogram were extended, which would result in false increment of earthquakes in these intervals. Exact Schuster's tests were performed for 8 histogram intervals cov5 ering LOD descending or ascending branch with one day excess. In some cases, 8-interval Schuster's test were performed for LOD maximum or minimum. In the Chile Trench the 28-histogram interval test was performed, characterizing the LOD graph typical for given time of earthquake occurrence. Declustering (Reasenberg, 1985) was not performed because aftershocks of earthquakes over $M>5.8$ are not numerous. The purpose of this study is not exact determination of the earthquake starts, but to investigate the influence of the Earth's rotation on earthquakes, which just for aftershocks is often important and well observable.

Histograms were performed for earthquake coincidence with sidereal amplitudes (LOD maximums and minimums) and for synodial amplitudes (full and new Moon). 25 These histograms were statistically evaluated, calculating the standard deviation from average of earthquake occurrence and calculating the Schuster's test. The areas of investigation chosen were in the Sumatra and Andaman Sea, Southeast Indian Ocean Ridge, Chilean Subduction zone, Mid-Atlantic Ridge, Haiti region, New Zealand region, Japan Trench Honshu region and East Pacific Rise. Earthquakes for period 1973-2011
SED

4, 33-130, 2012

\section{Earth's rotation variations and earthquakes 2010-2011}

L. Ostřihanský

Title Page

Abstract Introduction

Conclusions

References

Tables

Figures

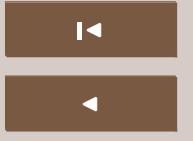

$\Delta$

Back

Close

Full Screen / Esc

Printer-friendly Version

Interactive Discussion 
were taken from NEIC USGS catalog, and for period 1963-1973 from ANSS catalogue. LOD variations were taken from IERS, which started its measurement in 1962, performing measurements in $\mathrm{ms}$.

\section{Results}

5 In 2007, Cochran and Vidale presented 12 interval histogram to determine the correlation of earthquakes with biweekly tides using 1428 earthquakes of global occurrence, and for the shear tidal stress histogram they received $0.584 \pm 0.94 \%$ more earthquakes than average. This resulted in non-existence of statistically significant correlation of earthquake timing with the biweekly tides. I performed a similar calculation for 10266 earthquakes of Sumatra and Andaman Sea using 15 interval histogram covering 14.77 days syzygy period and earthquakes in time span 1963-April 2011. The result gives $1.11 \pm 0.97 \%$ more earthquakes than average 17.73 earthquakes. This negative result can be confirmed by the Schuster's test (Table 2), which for 14-interval histogram gives parameter $p=19.88 \%$ and for 12 -interval histogram $p=14.88 \%$ (Fig. 7a). Great 15 surprise: the histograms for correlation of earthquakes with 13.66 days Earth's rotation variations show that the calculations for the 14 days histogram and for the more accurate 12 days histogram give the parameter $p=50.75 \%$ and $p=50.42 \%$, respectively - far more negative results than for biweekly tides. The solution is simple. The Earth's rotation variations expressed on LOD graph trigger earthquakes in both Earth's rotation acceleration and deceleration, and in the Sumatra Andaman Sea region in almost the same amount in both LOD graph extremes (Fig. 7b) and branches (Table 2). Performing the more accurate 8-interval histogram for LOD branches with one day excess, the result gives very low values of parameter $p=0.000059 \%$ and similar values for extremes of LOD graph in LOD maximum and minimum (Fig. $7 \mathrm{~b} 1-4)$. Figure $4 \mathrm{~m}$ from

\section{SED}

4, 33-130, 2012

Earth's rotation variations and earthquakes 2010-2011

L. Ostřihanský

Title Page

Abstract Introduction

Conclusions

References

Tables

Figures

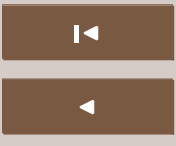

DI

Back

Close

Full Screen / Esc

Printer-friendly Version

Interactive Discussion ing and ascending branches of LOD graph. The verification by histogram confirms the excess of earthquakes in the Earth's rotation acceleration (Fig. 7d, d1, d2). Parameter 
$p=5.89 \%$ shows relatively probable correlation of earthquakes with Earth's rotation acceleration, whereas in the Earth's rotation deceleration, the parameter $p=87.9 \%$ shows quite irregular and improbable coincidence. The histogram for Chilean subduction zone (Fig. 7e) shows surprisingly good correlation: $p=1.30 \%$ for the whole 5 28-interval histogram. This confirms that together the LOD second minimum and 23 days before the first LOD maximum are the most probable earthquakes occurrences. Separating the 28 days histogram into four 8 days histograms shows that the first LOD maximum $p=1.39 \%$ is the most probable LOD area of earthquake triggering (Table 2 , Fig. 7e, e1-4).

10 Maximum attention was paid to earthquakes of the Mid Atlantic Ridge, to confirm assumption that the Haiti earthquake was triggered by quicker movement of the Northern Hemisphere at the moment of the Earth's maximum rotation (Fig. 4c). Next question was whether earthquakes in descending and ascending branches of LOD from MidAtlantic Ridge on 8 January 2010, 4 January 2010, 27 Dececember 2009 (Fig. 4b, c, 15 d) are real precursors of the Haiti earthquake. Figure $4 f$ shows that earthquakes from the Mid-Atlantic Ridge are triggered both in LOD maximums and minimums, giving very high value of parameter $p=52.84 \%$. Detailed Schuster's tests for 8 -interval histograms for branches and extremes confirm the clear correlation of earthquakes with LOD record (Table 2, Fig. 7f 1-4). Section 10-5 $\mathrm{N}$ in Northern Mid Atlantic Ridge shows for time span 2 May 1991-15 February 2001 regular changes of earthquakes triggering in the middle of descending and ascending LOD branches (Fig. 8). Later, no significant coincidence with LOD record occurred. Since 4 January 2010, an absolute absence of earthquakes occurred till 22 October 2010, probably owing to the Haiti earthquake of 12 January 2010. After 27 October 2010, an exclusive coincidence of earthquakes with LOD minimums occurred. Histograms (Fig. 7g, g1, g2) confirm this. In Fig. 7g during period 1999-July 2006, yellow bars show regular changing of earthquakes on both branches, later with increased number of earthquakes in LOD maximum. Summarizing all earthquakes from period 1973-2011, typical LOD minimum occurs, so the result is (Fig. $7 \mathrm{~g}$ blue bars) three earthquake maximums and absolute
SED

4, 33-130, 2012

\section{Earth's rotation variations and earthquakes 2010-2011}

L. Ostřihanský

Title Page

Abstract Introduction

Conclusions

References

Tables

Figures

14

- I

4

Back

Close

Printer-friendly Version

Interactive Discussion 
no correlation $p=88.70 \%$. Next section of northern part of the Mid-Atlantic Ridge was chosen $23.5-15^{\circ} \mathrm{N}$ and in narrow section $44-48^{\circ} \mathrm{W}$ where the Mid Atlantic Ridge is parallel with longitude (Fig. $7 \mathrm{~h}, \mathrm{~h} 1-4$ ) to avoid maximally the effect of transform faults intersecting perpendicularly with the Mid-Atlantic Ridge. Earthquakes on ascending 5 LOD branch are more numerous (Table 2) and do not correlate with LOD maximum (Fig. 7h2). There are earthquakes in the Mid-Atlantic Ridge preceding earthquakes in transform faults, including the Haiti earthquake of 12 January 2010. Another narrow section of the Mid-Atlantic Ridge covers section $2-2.5^{\circ} \mathrm{N}$, almost parallel with latitude in the middle close to equator $0^{\circ}$. Histogram (Fig. 7i) shows a large number of earth10 quakes outside LOD maximum or minimum but the number of earthquakes in descending branch is larger than it is with sections in the Northern Mid-Atlantic Ridge where the ratio desc./asce. LOD branch was reciprocal. The section of the southern part of the Mid-Atlantic Ridge (Fig. 7j, j1-2) shows an even larger number of earthquakes in descending LOD branch. Logically, in the mid-ocean ridge the branch containing 15 more earthquakes shows that the plate forward (in the Mid-Atlantic Ridge the plate on the west from the ridge) moves quicker than the plate behind. There is no doubt that the South American plate with the oceanic part behind moves quickly to the west, considering the large amount of oceanic lithosphere created between South America and Africa. How to explain the previous claim that the Northern Hemisphere moves quicker towards the west than the Southern Hemisphere? It contradicts the number of earthquakes in the Northern Mid-Atlantic Ridge, which are less numerous on the descending branch than on the ascending one. The reason is not only that the North American plate moves westward, but also the whole Eurasian plate, which as one of the largest continental plates, reacts more effectively on LOD variations and triggers more earthquakes on LOD ascending branch.

The Haiti region (Fig. 7k, k1, k2) shows the same amount of earthquakes on both LOD branches. However, the earthquake occurrence in the descending branch including the LOD minimum is the most probable $p=0.13 \%$.

SED

4, 33-130, 2012

Earth's rotation variations and earthquakes 2010-2011

L. Ostřihanský

Title Page

Abstract Introduction

Conclusions

References

Tables

Figures

14

4

Back

Close

Full Screen / Esc

Printer-friendly Version

Interactive Discussion 
Both earthquakes M7.1 Christchurch 3 September 2010 and M 6.3 Christchurch 21 February 2011 in New Zealand (Fig. 4i) were created as shallow earthquakes (5$10 \mathrm{~km}$ ) in eastern continuation of the Southeast Indian Ocean Ridge. The histograms for Southeast Indian Ocean Ridge (Fig. 7d, d1, d2) and the southern part of N. Zealand 5 (Fig. 7, I1, I2) are therefore very similar. Both regions, by the excess of earthquakes in descendant LOD branch, manifest the northward movement of the Indian plate during the Earth's rotation increment. The occurrence of earthquake 3 September 2010 in LOD minimum is very probable $p=2.11 \%$; nevertheless, histogram Fig. $7 \mathrm{l}$ also shows large number of earthquakes in LOD maximum peak.

10 Histogram for the Japan Trench in Honshu region (Fig. 7m, m1, m2) and the Schuster's test show very low probabilities of earthquakes occurrences in LOD extremes. Nevertheless, the LOD minimum shows an increase number of earthquakes. The large parameter $p=23.36 \%$ is incorrect (Fig. $7 \mathrm{~m} 1$ ), owing to evidently non-random distribution. Histograms for the northern part of the Mid-Atlantic Ridge show larger number of earthquakes in LOD ascending branch (Fig. 7f, f1, f2). Then it is possible that also in the eastern side of the Eurasian plate the ascending LOD branch will have more earthquakes. This is the case of the Japan Trench and the earthquake of 11 March 2011 near the east coast of Honshu M9.0 (Fig. 5a). In the histograms (Fig. 7m, m1,m2), the counting of earthquakes was stopped on 11 March 2011 to avoid aftershocks. The subduction zone of very old oceanic lithosphere of the Pacific plate is less sensitive or delayed on LOD variations and the Eurasian plate during its westward movement looses the continental lithosphere of Japan behind, which can also hide reaction on Earth's rotation variations.

Histogram for the East Pacific Rise shows that one side of the Rise moves quicker. Comparing the ratio for the southern part of the Mid-Atlantic Ridge 177/140 > 197/173 (Table 2) to the ratio for the East Pacific Rise, it is possible to conclude that the South American continent overrides the Nazca plate including the East Pacific Rise in future.

\section{SED}

4, 33-130, 2012

\section{Earth's rotation variations and earthquakes 2010-2011}

L. Ostřihanský

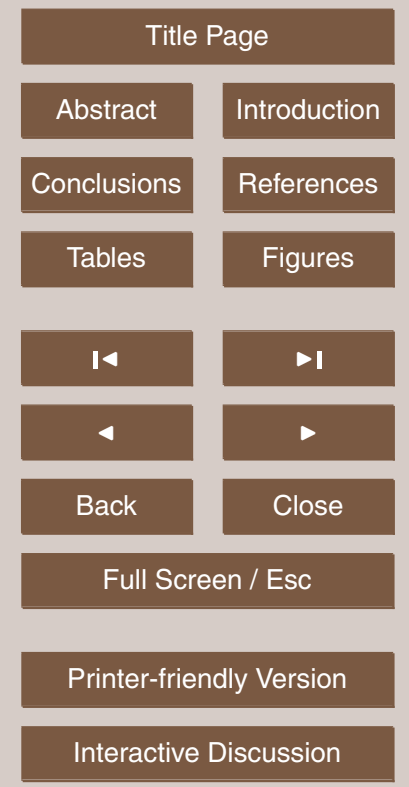




\section{Conclusions}

Triggering of earthquakes by the Earth's rotation variations is unequivocally proven by histograms showing an increment number of earthquakes during Earth's rotation maximums and minimums. Earthquakes are therefore triggered by both the Earth's rotation

5 deceleration and acceleration. Asymmetric distribution of earthquakes occurrence in histograms of LOD graph branches from mid-ocean ridges also give information about unilateral movement of plates in agreement with author's (Ostrihanský, 1997) conception of lithospheric plates movements and movement of mid-ocean ridges with the average speed of adjacent plates. The increased number of earthquakes in LOD branch 10 record during the Earth's acceleration of the Southeast Indian Ocean Ridge shows that the Indian plate moves northward, driven probably by the Eötvös force (Eötvös, 1913; Ostrihanský, 1997) or by attraction of Moon and Sun rectifying the Earth's flattening to ecliptic and Moon's orbit. The Mid-Atlantic Ridge and the East Pacific rise show the quicker westward movement of westerly sided plate by tidal friction or by inertia of plates during the Earth's rotation acceleration. However, the possibility of the plate movement is given by the gravity subsidence of all oceanic lithosphere older than 180 mil. years, i.e. by its subduction releasing place among plates. On the western side, the oceanic lithosphere of the Pacific plate drops down due to gravity and its old age and thickness on eastern side of Eurasian and Indian plates. From eastern side, the oceanic lithosphere of the Pacific plate is overridden by the American continent. Because earthquakes are triggered during the Earth's rotation acceleration or deceleration and earthquakes occur during distinctive lithospheric movements confirmed by shifts along faults, slips determined by seismology and most perfectly by GPS measurement (Figs. 5b and 6), any objections of Jordan (1974) and Ranalli (2000) about impossibility of the plate movement owing the high mantle viscosity are out of discussion. Remarkable repetition of Sumatran earthquakes 19 year ago exactly on one day in the full Moon on LOD minimum and close to solstice, probably in connection with nutation, only underline the effect of the Earth's rotation. Precursor of the Sumatra

\section{Earth's rotation variations and earthquakes 2010-2011}

L. Ostřihanský

Title Page

Abstract

Conclusions

Tables

14

4

Back

Full Screen / Esc

Printer-friendly Version

Interactive Discussion 
earthquake 2004 in the Macquarie Is. three days before can be completed by precursors of earthquake in Northern Mid-Atlantic Ridge 8 January 2010 before the Haiti earthquake 12 January 2010 (Fig. 4d) and by several LOD maximums and minimums before the Chilean earthquake of 27 February 2010 (Fig. 4f).

\section{Supplementary material related to this article is available online at:} http://www.solid-earth-discuss.net/4/33/2012/sed-4-33-2012-supplement.pdf.

Acknowledgements. I thank reviewer T. Gerya for providing me with literature inspiring me to revise and improve the paper.

\section{References}

Böhm von Böhmersheim, A.: Abplattung und Gebirgsbildung, Franz Deuticke, Leipzig und Wien, 1910.

Bostrom, R. C.: Westward displacement of the lithosphere, Nature, 234, 536-538, 1971.

Burša, M.: Secular tidal and non-tidal variations in the Earths rotation, Studia geoph et geodet., 31, 219-224, 1987.

\section{Cathles, L. M.: The viscosity of the Earth's mantle, Princeton Press, Princeton, NJ, 1975.}

Chebanenko, I. I.: Osnovnye zakonomernosti rozlomnoy tektoniki zemnoy kori, Izd. AN USSR, Kiev, 1963.

Cochran, E. S., Vidale, T. E., and Tanaka, S.: Earth tides can trigger shallow thrust fault earthquakes, Science, 306, 1164-1166, 2004.

20 Cochran, E. S. and Vidale, J. L.: Comments on "Tidal synchronicity of 26 December 2004 Sumatran earthquake and its aftershocks" by Crockett, R. G. M., Gilmore, G. K., Phillips, P. S., and Gilbertson, D. D., Geophys. Res. Lett., 34(L04302), 1-2, 2007.

Crespi, M., Cuffaro, M., Doglioni, C., Giannone, F., and Riguzzi, F.: Space geodesy validation of the global lithospheric flow, Geophys. J. Int., 168, 491-506, 2007.

Crockett, R. G., Gilmore, G. K., Phillips, P. S., and Gilbertson, D. D.: Tidal synchronicity of the 26 December 2004 Sumatran earthquake and its aftershocks, Geophys. Res. Lett., 33, L19302, doi:10.1029/2006GL027074, 2006.
SED

4, 33-130, 2012

\section{Earth's rotation variations and earthquakes 2010-2011}

L. Ostřihanský

\section{Title Page}

\section{Abstract}

Introduction

Conclusions

References

Tables

Figures

14

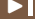

Back

Close

Full Screen / Esc

Printer-friendly Version

Interactive Discussion 
Darwin, G. H.: On the tidal friction of a planet attended by several satellites and on the evolution of the solar system, Philos. Trans., 172, 491-435, 1881.

Doglioni, C., Carminati, E., Cuffaro, and Srocca, D.: Subduction kinematics and dynamic constraints, Earth Sci. Rev., 83, 125-175, 2007.

5 Eötvös, L.: Verhandlungen der 17. Algem. Konferenz d. Internat. Erdmessungen, Part 1, Astronomische Gesellschaft Hamburg, 111 pp., 1913.

Hey, R. N. and Vogt, P. R.: Spreading centers jumps near the Galapagos hotspot, Tectonophysics, 37, 41-52, 1977.

Hide, R.: Rotation of the atmospheres of the Earth and planets, Philos. T. Roy. Soc. Lond., 313, 107-121, 1984.

Holmes, A.: Radioactivity and the Earth movement, Trans. Geol. Soc. Glasg., 28, 559-606, 1939.

Jordan, T. H.: Some comments on tidal drag as a mechanism for driving plate motions, J. Geophys. Res., 79, 2141-2142, 1974.

Kalenda, P., Neumann, L., Skalský, L., Ostřihanský, L., Kopf, T., and Croll, J.: Vertical static pendulums, earthquake prediction and global tectonics, Monography issued by International Academy, 1. vydání, prosinec 2011, ISBN: 9788090512603, 2010.

Knopoff, L. and Leeds, A.: Lithospheric momenta and the deceleration of the Earth, Nature, 237, 93-95, 1972.

20 Madariaga, R., Ruegg, J. C., Vigny, C., Mettois, M., Campos, J., and Kausel, E.: The Mw 8.8 Maule earthquake of 27 February 2010, a tale of a long expected earthquake, Abstract EGU2010-15700, in: Large Magnitude Earthquakes and Tsunami Activity in 2010: Views on the Haiti and Chile events, edited by: Bezzeghoud, M., convenor. EGU General Assembly, Vienna 2010.

25 MacDonald, G. J. F.: The deep structure of the continents, Rev. Geophys., 1, 587-665, 1963.

McKenzie, D. and Weiss, N.: Speculations on the thermal and tectonic history of the Earth, Geophys. J. Roy. Astr. S., 42, 131-174, 1975.

Moore, G. W.: Westward tidal drag as the driving force of plate tectonics, Geology, 1, 99-100, 1973.

30 Munk, W. H. and MacDonald, G. J. F.: The rotation of the Earth, University Press, Cambridge, 1960.

NASA ARIA Preliminary Coseismic Displacement, 11 March 2011 Sendai-Oki earthquake.

Ostrihanský, L.: Forces causing the movement of plates, poster presented at IUGG XX. Gen-

SED

4, 33-130, 2012

\section{Earth's rotation \\ variations and \\ earthquakes \\ 2010-2011}

L. Ostřihanský

Title Page

Abstract

Introduction

Conclusions

References

Tables

Figures

14

$>\mathbf{I}$

4

Back

$\triangleright$

Close

Full Screen / Esc

Printer-friendly Version

Interactive Discussion 
eral Assembly, Vienna, 11-21 August 1991.

Ostřihanský, L.: The causes of lithospheric plates movements, Charles University Prague, Chair of Geography and Geoecology, available at: http://geo.mff.cuni.cz/ ostrihansky/, last access: December 2011, 1997.

5 Ostrihanský, L.: Plate movements, earthquakes and variations of the Earth's rotation, Acta Univ. Carol.-Geol., 48, 89-98, 2004.

Ostrihanský, L.: Lithospheric resonances of the Earth's rotation, Abstract EGU2010-1715, in: Unresolved problems in plate tectonics: kinematic reconstructions, plate driving forces, and plate boundary interactions, edited by: Doglioni, C., convener, EGU General Assembly, Vienna 2010.

Ranalli, G.: Westward drift of the lithosphere: not a result of rotational drag, Geophys. J. Int., 141, 535-537, 2002.

Reasenberg, P.: Second-order moment of central California seismicity 1969-1982, J. Geophys. Res., 90, 5479-5495, 1985.

15 Report from Wired Science, available at: http://www.wired.com/wiredscience/2010/03/ chile-earthquake-moved-entire-city-10-feet-to-the-west/\#ixzzOhr4xF7ZM, 2010.

Rosen, R. D., Salstein, D. A., Eubanks, T. M., Dickey, J. D., and Steppe, J. A.: El Nino signal in atmospheric angular momentum and Earth rotation, Science, 225, 411, 1984.

Schmidt, R. E.: Die Geomechanik des Erdinneren und ihre Auswirkung auf die Erdkruste, Relationes Annuae Instituti Geologici Publici Hungarici, B. Disputationes, 159-231, 1948.

Schuster, A.: On lunar and solar periodicities of earthquakes, P. R. Soc. London, 61, 445-465, 1897.

Schuster, A.: Some problems of seismology, B. Seismol. Soc. Am., 1, 97-100, 1911.

Stacey, F. D.: Physics of the Earth, John Willey \& Sons, 2 Edn., 1977.

Stovas, M., V.: Neronomirnost obertanya Zemli, kak planetarnogeomorfologichnye tak geotektonichnye faktori, Geol. Zh. t., XVII, 3, 58-69, 1957.

SOEST News, Preliminary Coseismic Displacement Field M 8.8 Maule Earthquake, Chile, 27 February 2010.

USGS Poster of the Haiti Earthquake of 12 January 2010 - Magnitude 7.0, available at: http://earthquake.usgs.gov/earthquakes/eqarchives/poster/2010/20100112.php, 2010.

Tanaka, S., Ohtake, M., and Sato, H.: Evidence for tidal triggering of earthquakes as revealed from statistical analysis of global data, J. Geophys. Res., 107(B10), 2211, doi:10.1029/2001JB001577, 2002.
SED

4, 33-130, 2012

\section{Earth's rotation variations and earthquakes 2010-2011}

L. Ostřihanský

Title Page

Abstract

Introduction

Conclusions

References

Tables

Figures

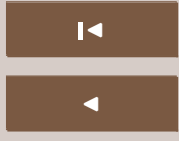

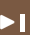

Back

Close

Full Screen / Esc

Printer-friendly Version

Interactive Discussion 
Varga, P. and Denis, C.: Geodetic aspects of seismological phenomena, J. Geod., 84, 107-121, doi:10.1007/s00190-009-0350-1, 2010.

Veronnet, A.: Rotation de l'elipsoide heterogene et figure exacte de la Terre, J. Math. Pure. Appl., 6(VIII), 331-463, 1912.

5 Veronnet, A.: Constitution et evolution d'univers, Gaston Doin et Cie., Paris, 62-63, 1927.

Vine, F. J. and Matthews, D. H.: Magnetic anomalies over oceanic ridges, Nature, 228, 947949, 1963.

Wahr, J. M.: The Earth's rotation, Ann. Rev. Earth Planet. Sci., 16, 231-249, 1988.

Weems, R. E. and Perry, W. H.: Strong correlation of major earthquakes with solid-earth tides in part of United States, Geology, 17(7), 661-664, 1989.

Wilcock, W. S. D.: Tidal triggering of earthquakes in the Northeast Pacific Ocean, Geophys J. Int., 179, 1055-1070, doi:10.1111/j.1366-246X.2009.04319.x, 2009.

4, 33-130, 2012

\section{Earth's rotation variations and earthquakes 2010-2011}

L. Ostřihanský

\section{Title Page}

Abstract

Conclusions

Tables

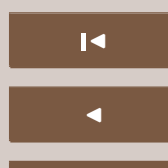

Back
Introduction

References

Figures

$\Delta$

Close

Full Screen / Esc

Printer-friendly Version

Interactive Discussion 
Table 1. List of 17 earthquakes magnitudes over M 5.8 that occurred in the solstices time, taken from 49 earthquakes triggered in LOD minimums in chosen rectangle $14^{\circ} \mathrm{N}-7^{\circ} \mathrm{S}, 106-$ $90^{\circ}$ E covering the Sumatra and Andaman Sea from 1963 to 2011, totaling 264 earthquakes.

\begin{tabular}{|c|c|c|c|c|}
\hline $\begin{array}{l}\text { Date of } \\
\text { earthquake }\end{array}$ & Syzygy & Magnitude & Date of syzygy & $\begin{array}{l}\text { Date of LOD } \\
\text { minimum }\end{array}$ \\
\hline 21.12 .2010 & -) & 5.9 & 21.12 .2010 & 21.12 .2010 \\
\hline 12.6.2010 & - & 7.5 & 12.6.2010 & 12.6.2010 \\
\hline 22.12 .2007 & () & 6.1 & 23.12.2007 & 24.12.2007 \\
\hline 22.12 .2006 & - & 6.2 & 20.12.2006 & 21.12 .2006 \\
\hline 27.6.2006 & - & 6.3 & 26.12.2006 & 25.12.2006 \\
\hline 5.7 .2005 & - & 6.7 & 6.7.2005 & 5.7 .2005 \\
\hline 26.12.2004 & (); & 9.1 & 26.12.2004 & 26.12.2004 \\
\hline 15.1 .2002 & 0 & 6.1 & 13.1.2002 & 14.1 .2002 \\
\hline 17.7.1997 & () & 5.9 & 20.7.1997 & 17.7.1997 \\
\hline 20.1.1993 & 0 & 6.2 & 22.1.1993 & 20.1.1993 \\
\hline 22.12.1991 & (): & 5.8 & 21.12.1991 & 21.12.1991 \\
\hline 29.12.1990 & (): & 6.0 & 31.12 .1990 & 31.12 .1990 \\
\hline 27.12.1985 & (): & 6.6 & 27.12.1985 & 27.12.1985 \\
\hline 11.1.1979 & (-) & 6.2 & 13.1.1979 & 13.1.1979 \\
\hline 17.12.1975 & () & 6.2 & 18.12.1975 & 18.12.1975 \\
\hline 2.7.1970 & $\bullet$ & 5.8 & 3.7.1970 & 2.7.1970 \\
\hline 16.12 .1963 & $\bullet$ & 6.0 & 16.12.1963 & 17.12.1963 \\
\hline
\end{tabular}

\section{Earth's rotation variations and earthquakes 2010-2011}

L. Ostřihanský

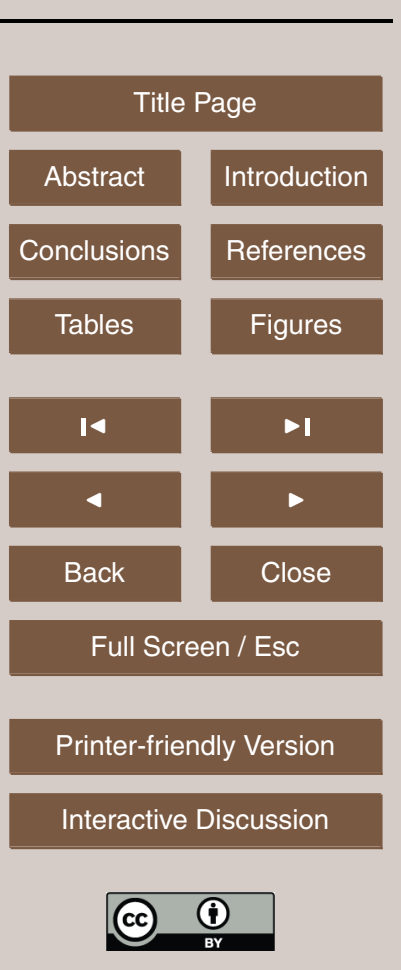


Table 2. Results of Schuster's test and ratio of earthquakes on descending and ascending branches of LOD record in investigated areas: Sumatra and Andaman Sea, Southeast Indian Ocean Ridge, Chilean subduction zone, Mid-Atlantic Ridge Haiti region, New Zealand region, Japan Trench and East Pacific Rise.

\begin{tabular}{|c|c|c|c|c|c|c|c|c|c|}
\hline Locality & Area & $\begin{array}{l}\text { Date } \\
\text { range }\end{array}$ & $\begin{array}{l}\text { Type of } \\
\text { correlation }\end{array}$ & $\begin{array}{c}\text { Number } \\
\text { of histogr. } \\
\text { intervals }\end{array}$ & $\begin{array}{l}\text { Schuster's } \\
\text { test }\end{array}$ & $\begin{array}{l}\text { Number } \\
\text { of earth- } \\
\text { quakes }\end{array}$ & $\begin{array}{l}\text { Minimum } \\
\text { earthuake } \\
\text { magnitude }\end{array}$ & $\begin{array}{l}\text { Earthquakes } \\
\text { desc.//ssc. } \\
\text { LOD branch }\end{array}$ & Fig. \\
\hline \multirow{10}{*}{$\begin{array}{l}\text { Sumatra and } \\
\text { Andaman Sea }\end{array}$} & \multirow{10}{*}{$\begin{array}{l}14^{\circ} \mathrm{N}-7^{\circ} \mathrm{S} \\
106-90^{\circ} \mathrm{E}\end{array}$} & \multirow{10}{*}{$\begin{array}{l}\text { 1963- } \\
\text { IV.2011 }\end{array}$} & Syzygy & 14 & $19.88 \%$ & 254 & 5.8 & \multirow{10}{*}{$131 / 133$} & $7 a$ \\
\hline & & & $\begin{array}{l}\text { Syzygy } \\
\text { LOD } 13.66 \\
\text { days record }\end{array}$ & $\begin{array}{l}12 \\
12\end{array}$ & $\begin{array}{l}14.87 \% \\
50.42 \%\end{array}$ & $\begin{array}{c}244 \\
219.7\end{array}$ & $\begin{array}{l}5.8 \\
5.8\end{array}$ & & $\begin{array}{l}7 \mathrm{a} \\
7 \mathrm{~b}\end{array}$ \\
\hline & & & $\begin{array}{l}\text { LOD } 13.66 \\
\text { days record }\end{array}$ & 14 & $50.75 \%$ & 264 & 5.8 & & $7 \mathrm{~b}$ \\
\hline & & & $\begin{array}{l}\text { LOD desc. } \\
\text { branch }\end{array}$ & 8 & $0.000059 \%$ & 151 & 5.8 & & $7 \mathrm{~b} 1$ \\
\hline & & & $\begin{array}{l}\text { LOD asce. } \\
\text { branch }\end{array}$ & 8 & $0.0016 \%$ & 146 & 5,8 & & $7 \mathrm{~b} 2$ \\
\hline & & & $\begin{array}{l}\text { Negative } \\
\text { LOD peak }\end{array}$ & 8 & $0.000073 \%$ & 151 & 5.8 & & $7 \mathrm{~b} 3$ \\
\hline & & & $\begin{array}{l}\text { Positive } \\
\text { LOD peak }\end{array}$ & 8 & $0.010 \%$ & 138 & 5.8 & & $7 \mathrm{~b} 4$ \\
\hline & & & $\begin{array}{l}\text { Inflexion } \\
13.66 \text { days }\end{array}$ & 14 & $47.86 \%$ & 283 & 5.8 & & $7 \mathrm{c}$ \\
\hline & & & $\begin{array}{l}\text { Inflexion } \\
\text { desc. bra. }\end{array}$ & 8 & $4.11 \%$ & 164 & 5.8 & & $7 \mathrm{c}$ \\
\hline & & & $\begin{array}{l}\text { Inflexion } \\
\text { asc. bran. }\end{array}$ & 8 & $1.89 \%$ & 148 & 5,8 & & $7 \mathrm{c}$ \\
\hline \multirow{3}{*}{$\begin{array}{l}\text { Southeast } \\
\text { Indian } \\
\text { Ocean Ridge }\end{array}$} & \multirow[t]{3}{*}{$\begin{array}{l}45-60^{\circ} \mathrm{S} \\
165-90^{\circ} \mathrm{E}\end{array}$} & \multirow[t]{3}{*}{$\begin{array}{l}2008- \\
\text { VII2011 }\end{array}$} & $\begin{array}{l}\text { LOD } 13.66 \\
\text { days recors }\end{array}$ & 14 & $9.54 \%$ & 167 & 3.0 & \multirow[t]{3}{*}{$92 / 75$} & $7 d$ \\
\hline & & & $\begin{array}{l}\text { LOD desc. } \\
\text { branch }\end{array}$ & 8 & $5.89 \%$ & 101 & 3.0 & & $7 \mathrm{~d} 1$ \\
\hline & & & $\begin{array}{l}\text { LOD asce. } \\
\text { branch }\end{array}$ & 8 & $87.90 \%$ & 80 & 3.0 & & $7 \mathrm{~d} 2$ \\
\hline \multirow[t]{5}{*}{$\begin{array}{l}\text { Chilean } \\
\text { subduction } \\
\text { zone }\end{array}$} & \multirow[t]{5}{*}{$\begin{array}{l}5^{\circ} \mathrm{N}-50^{\circ} \mathrm{S} \\
60-80^{\circ} \mathrm{W}\end{array}$} & \multirow[t]{5}{*}{$\begin{array}{l}\text { 1973- } \\
\text { IV.2011 }\end{array}$} & $\begin{array}{l}\text { LOD } 27.32 \\
\text { days record } \\
\text { Inflex. point }\end{array}$ & 28 & $1.30 \%$ & 349 & 6.0 & \multirow[t]{5}{*}{$186 / 203(93 / 123)^{*}$} & $7 e$ \\
\hline & & & LOD first & $\begin{array}{c}8 \\
\text { maximum }\end{array}$ & $1.39 \%$ & 214 & 6.0 & & $7 e 1$ \\
\hline & & & LOD first & $\begin{array}{c}8 \\
\text { minimum }\end{array}$ & $10.66 \%$ & 88 & 6.0 & & $7 \mathrm{e} 2$ \\
\hline & & & LOD sec. & $\begin{array}{c}8 \\
\text { maximum }\end{array}$ & $18.35 \%$ & 80 & 6.0 & & $7 \mathrm{e} 3$ \\
\hline & & & LOD sec. & $\stackrel{8}{8}$ & $50.66 \%$ & 111 & 6.0 & & $7 \mathrm{e} 4$ \\
\hline \multirow[t]{9}{*}{$\begin{array}{l}\text { Mid-Atlantic } \\
\text { Ridge }\end{array}$} & \multirow[t]{5}{*}{$\begin{array}{l}28-5^{\circ} \mathrm{N} \\
35-55^{\circ} \mathrm{W} \\
\text { northern part }\end{array}$} & \multirow[t]{5}{*}{$\begin{array}{l}2000- \\
\text { VII2011 }\end{array}$} & $\begin{array}{l}\text { LOD } 13.66 \\
\text { days record }\end{array}$ & 14 & $52.84 \%$ & 348 & 3.0 & \multirow[t]{5}{*}{$162 / 186$} & $7 f$ \\
\hline & & & $\begin{array}{l}\text { LOD desc. } \\
\text { branch }\end{array}$ & 8 & $0.012 \%$ & 186 & 3.0 & & $7 f 1$ \\
\hline & & & $\begin{array}{l}\text { LOD asce. } \\
\text { branch }\end{array}$ & 8 & $0.042 \%$ & 201 & 3.0 & & $7 f 2$ \\
\hline & & & $\begin{array}{l}\text { Negative } \\
\text { LOD peak }\end{array}$ & 8 & $0.052 \%$ & 186 & 3.0 & & $7 \uparrow 3$ \\
\hline & & & $\begin{array}{l}\text { Positive } \\
\text { LOD peak }\end{array}$ & 8 & $0.00022 \%$ & 185 & 3.0 & & $7 f 4$ \\
\hline & \multirow{4}{*}{$\begin{array}{l}10-5^{\circ} \mathrm{N} \\
35-55^{\circ} \mathrm{W}\end{array}$} & \multirow{3}{*}{$\begin{array}{l}1973- \\
\text { Vl.2011 }\end{array}$} & $\begin{array}{l}\text { LOD } 13.66 \\
\text { days record }\end{array}$ & 14 & $88.70 \%$ & 219 & 3.0 & \multirow[t]{3}{*}{$111 / 108$} & $7 \mathrm{~g}$ \\
\hline & & & $\begin{array}{l}\text { LOD desc. } \\
\text { branch }\end{array}$ & 8 & $78.76 \%$ & 110 & 3.0 & & $7 \mathrm{~g} 1$ \\
\hline & & & $\begin{array}{l}\text { LOD asce. } \\
\text { branch }\end{array}$ & 8 & $1.44 \%$ & 120 & 3.0 & & $7 \mathrm{~g} 2$ \\
\hline & & $\begin{array}{l}1999- \\
\text { VII.2006 }\end{array}$ & $\begin{array}{l}\text { LOD13.66 } \\
\text { days record }\end{array}$ & 14 & $0.81 \%$ & 57 & 3.0 & $22 / 35$ & $7 \mathrm{~g}$ \\
\hline
\end{tabular}

SED

4, 33-130, 2012

\section{Earth's rotation variations and earthquakes 2010-2011}

L. Ostřihanský

\section{Title Page}

\section{Abstract}

Introduction

Conclusions

References

Tables

Figures
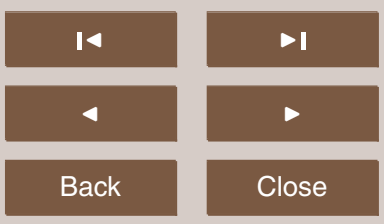

Back

Full Screen / Esc

Printer-friendly Version

Interactive Discussion 
Table 2. Continued.

\begin{tabular}{|c|c|c|c|c|c|c|c|c|c|}
\hline Locality & Area & $\begin{array}{l}\text { Date } \\
\text { range }\end{array}$ & $\begin{array}{l}\text { Type of } \\
\text { correlation }\end{array}$ & $\begin{array}{l}\text { Number } \\
\text { of histogr. } \\
\text { intervals }\end{array}$ & $\begin{array}{c}\text { Schuster's } \\
\text { test }\end{array}$ & $\begin{array}{l}\text { Number } \\
\text { of earth- } \\
\text { quakes }\end{array}$ & $\begin{array}{l}\text { Minimum } \\
\text { earthquake } \\
\text { magnitude }\end{array}$ & $\begin{array}{l}\text { Earthquakes } \\
\text { desc./asc. } \\
\text { LOD branch }\end{array}$ & Fig. \\
\hline \multirow{5}{*}{$\begin{array}{l}\text { Mid-Atlantc } \\
\text { Ridge } \\
\text { Parallel with } \\
\text { meridian }\end{array}$} & $\begin{array}{l}23.5-15^{\circ} \mathrm{N} \\
44-48^{\circ} \mathrm{W}\end{array}$ & $\begin{array}{l}1976- \\
\text { V.2011 }\end{array}$ & $\begin{array}{l}\text { LOD } 13.66 \\
\text { days record }\end{array}$ & 14 & $4.88 \%$ & 110 & 3.0 & $107 / 119$ & $7 \mathrm{~h}$ \\
\hline & & & $\begin{array}{l}\text { LOD desc. } \\
\text { branch }\end{array}$ & 8 & $0.0039 \%$ & 129 & 3.0 & & 7 h1 \\
\hline & & & $\begin{array}{l}\text { LOD asce. } \\
\text { branch }\end{array}$ & 8 & $25.43 \%$ & 126 & 3.0 & & 7 h2 \\
\hline & & & $\begin{array}{l}\text { Negative } \\
\text { LOD peak }\end{array}$ & 8 & $0.013 \%$ & 139 & 3.0 & & 7 h3 \\
\hline & & & $\begin{array}{l}\text { Positive } \\
\text { LOD peak }\end{array}$ & 8 & $0.36 \%$ & 107 & 3.0 & & 7 h 4 \\
\hline \multirow{3}{*}{$\begin{array}{l}\text { Mid-Atlantic } \\
\text { Ridge } 0^{\circ} \\
\text { Parallel with } \\
\text { equator }\end{array}$} & $\begin{array}{l}2-2.5^{\circ} \mathrm{N} \\
10-35^{\circ} \mathrm{W} \\
\text { Central part }\end{array}$ & $\begin{array}{l}2000- \\
11.2011\end{array}$ & $\begin{array}{l}\text { LOD } 13.66 \\
\text { days record }\end{array}$ & 14 & $0.34 \%$ & 266 & 3.0 & $143 / 123$ & $7 \mathrm{i}$ \\
\hline & & & $\begin{array}{l}\text { LOD desc. } \\
\text { branch }\end{array}$ & 8 & $1.00 \%$ & 162 & 3.0 & & $7 i 1$ \\
\hline & & & $\begin{array}{l}\text { LOD asce. } \\
\text { branch }\end{array}$ & 8 & $35.76 \%$ & 133 & 3.0 & & $7 \mathrm{i} 2$ \\
\hline \multirow[t]{4}{*}{$\begin{array}{l}\text { Mid-Atlantic } \\
\text { Ridge }\end{array}$} & $\begin{array}{l}10-45^{\circ} \mathrm{S} \\
10-20^{\circ} \mathrm{W}\end{array}$ & $\begin{array}{l}2000- \\
\text { VII. } 2011\end{array}$ & $\begin{array}{l}\text { LOD } 13.66 \\
\text { days record }\end{array}$ & 14 & $0.024 \%$ & 317 & 3.0 & $177 / 140$ & $7 \mathrm{j}$ \\
\hline & & & LOD 13.66 & $\begin{array}{c}12 \\
\text { days record }\end{array}$ & $0.18 \%$ & 272.9 & 3.0 & & \\
\hline & & & $\begin{array}{l}\text { LOD desc. } \\
\text { branch }\end{array}$ & 8 & $0.00008 \%$ & 203 & 3.0 & & $7 \mathrm{j} 1$ \\
\hline & & & $\begin{array}{l}\text { LOD asce. } \\
\text { branch }\end{array}$ & 8 & $0.062 \%$ & 154 & 3.0 & & $7 \mathrm{j} 2$ \\
\hline \multirow[t]{5}{*}{ Haiti region } & $\begin{array}{l}20-16^{\circ} \mathrm{N} \\
65-85^{\circ} \mathrm{W}\end{array}$ & $\begin{array}{l}1976- \\
1.2010\end{array}$ & $\begin{array}{l}\text { LOD } 13.66 \\
\text { days record }\end{array}$ & 14 & $4.95 \%$ & 324 & 4.5 & $162 / 162$ & $7 \mathrm{k}$ \\
\hline & & & $\begin{array}{l}\text { LOD desc. } \\
\text { branch }\end{array}$ & 8 & $0.13 \%$ & 182 & 4.5 & & $7 \mathrm{k} 1$ \\
\hline & & & $\begin{array}{l}\text { LOD asce. } \\
\text { branch }\end{array}$ & 8 & $84.16 \%$ & 176 & 4.5 & & $7 \mathrm{k} 2$ \\
\hline & & & $\begin{array}{l}\text { Negative } \\
\text { LOD peak }\end{array}$ & 8 & $26.00 \%$ & 210 & 4,5 & & $7 \mathrm{k} 3$ \\
\hline & & & $\begin{array}{l}\text { Positive } \\
\text { LOD peak }\end{array}$ & 8 & $22.45 \%$ & 164 & 4,5 & & $7 \mathrm{k} 4$ \\
\hline \multirow[t]{4}{*}{$\begin{array}{l}\text { New Zealand } \\
\text { region }\end{array}$} & $\begin{array}{l}41-52^{\circ} \mathrm{S} \\
160-175^{\circ} \mathrm{E}\end{array}$ & $\begin{array}{l}\text { 1973- } \\
\text { III.2011 }\end{array}$ & $\begin{array}{l}\text { LOD } 13.66 \\
\text { days record }\end{array}$ & 14 & $4.85 \%$ & 175 & 5.0 & $98 / 77$ & 71 \\
\hline & & & $\begin{array}{l}\text { LOD desc. } \\
\text { branch }\end{array}$ & 8 & $2.11 \%$ & 109 & 5.0 & & 711 \\
\hline & & & $\begin{array}{l}\text { LOD asce. } \\
\text { branch }\end{array}$ & 8 & $22.03 \%$ & 88 & 5.0 & & 712 \\
\hline & & $\begin{array}{l}2000- \\
\text { VII.2011 }\end{array}$ & $\begin{array}{l}\text { LOD } 13.66 \\
\text { days record }\end{array}$ & 14 & $58.23 \%$ & 85 & 5.0 & & 71 \\
\hline \multirow[t]{3}{*}{$\begin{array}{l}\text { Japan Trench } \\
\text { Honshu region }\end{array}$} & $\begin{array}{l}36-42^{\circ} \mathrm{N} \\
138-145^{\circ} \mathrm{E}\end{array}$ & $\begin{array}{l}1963- \\
\text { III.2011 }\end{array}$ & $\begin{array}{l}\text { LOD } 13.66 \\
\text { days record }\end{array}$ & 14 & $18.47 \%$ & 173 & 5.8 & $83 / 90$ & $7 \mathrm{~m}$ \\
\hline & & & $\begin{array}{l}\text { LOD desc. } \\
\text { branch }\end{array}$ & 8 & $23.36 \%$ & 91 & 5.8 & & $7 \mathrm{~m} 1$ \\
\hline & & & $\begin{array}{l}\text { LOD asce. } \\
\text { branch }\end{array}$ & 8 & $26.17 \%$ & 99 & 5.8 & & $7 \mathrm{~m} 2$ \\
\hline \multirow[t]{3}{*}{$\begin{array}{l}\text { East Pacific } \\
\text { Rise }\end{array}$} & $0-30^{\circ} \mathrm{S}$ & $\begin{array}{l}2000- \\
\text { Vl.2011 }\end{array}$ & $\begin{array}{l}\text { LOD } 13.66 \\
\text { days record }\end{array}$ & 14 & $50.11 \%$ & 370 & 3.0 & $197 / 173$ & $7 n$ \\
\hline & & & $\begin{array}{l}\text { LOD desc. } \\
\text { branch }\end{array}$ & 8 & $2.14 \%$ & 218 & 3.0 & & $7 \mathrm{n} 1$ \\
\hline & & & $\begin{array}{l}\text { LOD asce. } \\
\text { branch }\end{array}$ & 8 & $11.94 \%$ & 195 & 3.0 & & $7 \mathrm{n} 2$ \\
\hline
\end{tabular}

\section{Earth's rotation variations and earthquakes 2010-2011}

\section{Ostřihanský}

Title Page

\section{Abstract}

Introduction

Conclusions

References

Tables

Figures

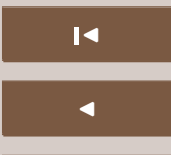

Back

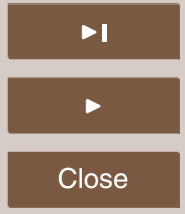

Full Screen / Esc

Printer-friendly Version

Interactive Discussion 


\section{Denali Fault Alaska}

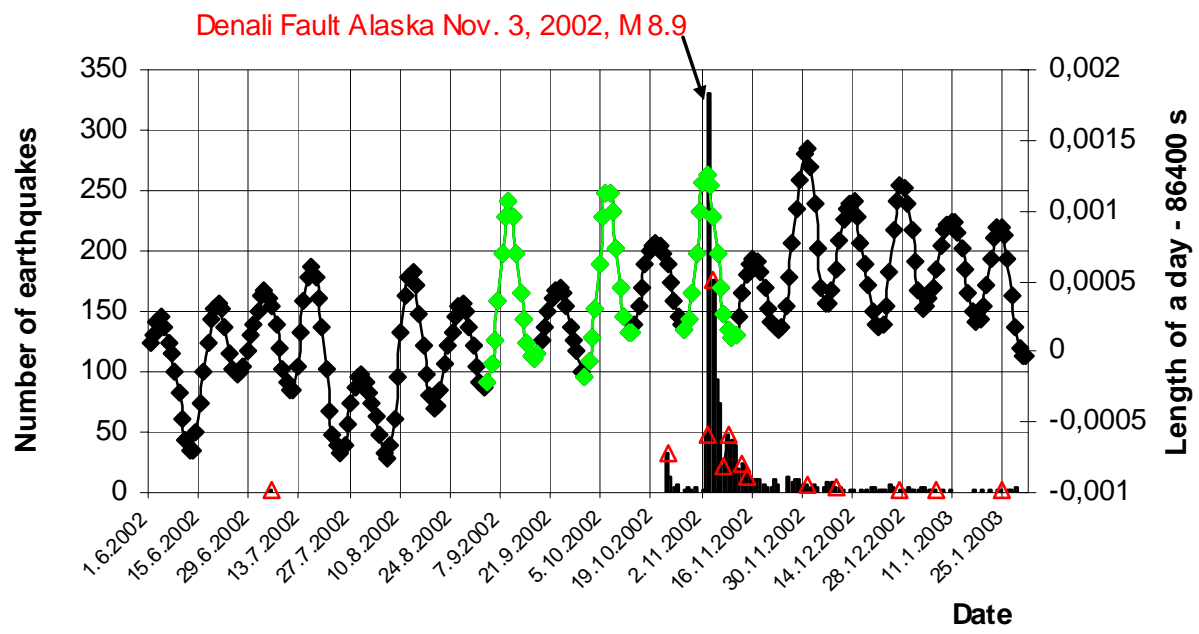

Fig. 1. The coincidence of LOD record and the 3 November 2002 Denali Fault Alaska earthquake $(M=8.9)$ evoked by the resonance effect of 27.6 days repeating LOD amplitudes (marked in green color). Earthquakes of magnitude $M>4.8$ are marked by triangles.
Earth's rotation variations and earthquakes 2010-2011

L. Ostřihanský

\section{Abstract}

Conclusions

\section{Tables}

14

4

Back

Full Screen / Esc

Printer-friendly Version

Interactive Discussion 


\section{Sumatra and Andaman Sea}

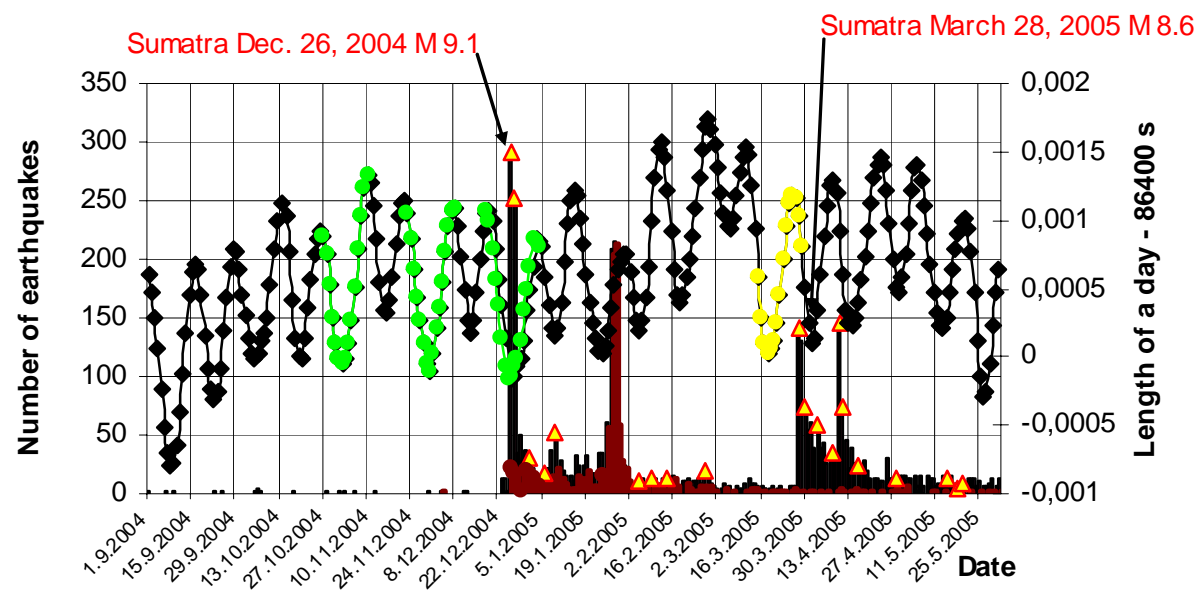

Fig. 2. The coincidence of LOD record and the 26 December 2004 Sumatra earthquake $(M=9.1)$ evoked by the negative repeating amplitudes of LOD record (marked in green color). The earthquake of 28 March 2005 Sumatra $(M=8.6)$ had been created by the extreme $(1.5 \mathrm{~ms})$ previously long lasting Earth's velocity increment (marked in yellow color), but owing to vicinity of vernal point it was triggered 2 days after the LOD maximum. Earthquakes of magnitude $M>5.8$ are marked by triangles. Earthquakes from Andaman Sea are marked in violet.

\section{Earth's rotation variations and earthquakes 2010-2011}

L. Ostřihanský

\section{Title Page}

Abstract

Conclusions

\section{Tables}

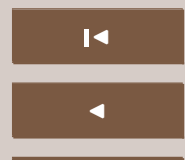

Back

\section{Introduction}

References
Full Screen / Esc

Printer-friendly Version

Interactive Discussion 
M 8.6 Sumatra 28.3.05 earthquake delay

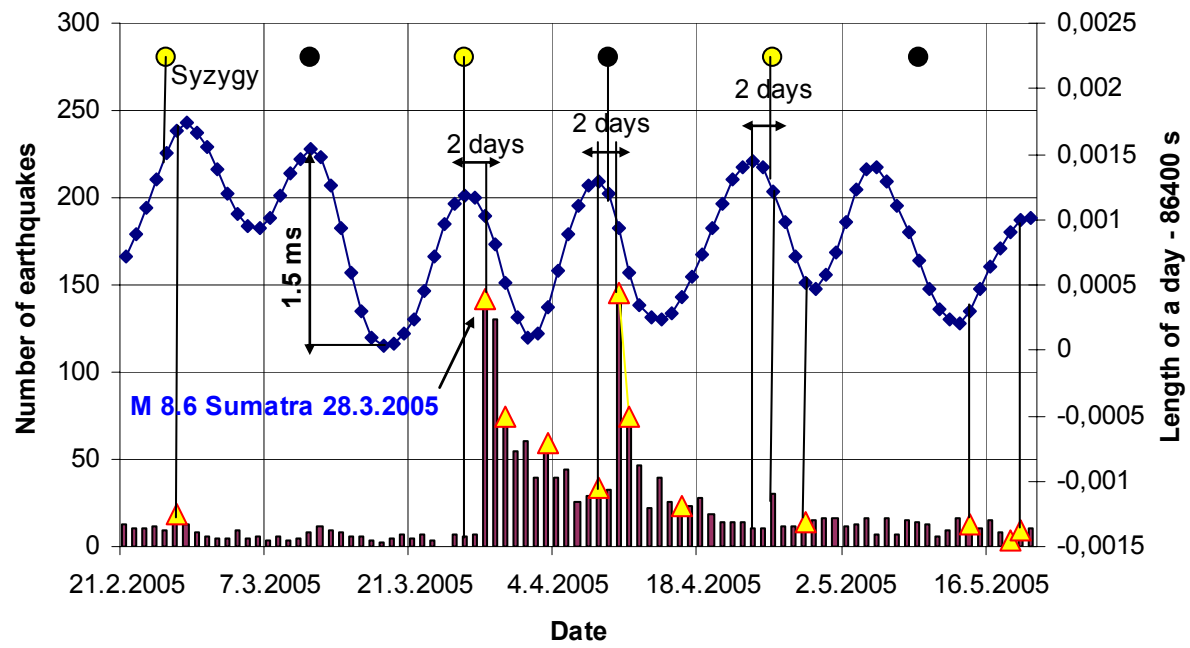

Fig. 3a. The $1.5 \mathrm{~ms}$ extreme velocity increment and following deceleration owing to vicinity of vernal point the 28 March 2005 earthquake was triggered on LOD maximum, however, with 2 days delay. Aftershocks repeated this 2 days delay twice with 13.66 (1/2 of Moon's sidereal period) LOD variations. Earthquakes $M>5.8$ are marked by triangle.

\section{Earth's rotation variations and earthquakes 2010-2011}

L. Ostřihanský

\section{Title Page}

\section{Abstract}

Conclusions

\section{Tables}

14

4

Back

\section{Introduction}

References

\section{Full Screen / Esc}

Printer-friendly Version

Interactive Discussion 
Earthquake Sumatra December 26, 2004, M 9.1

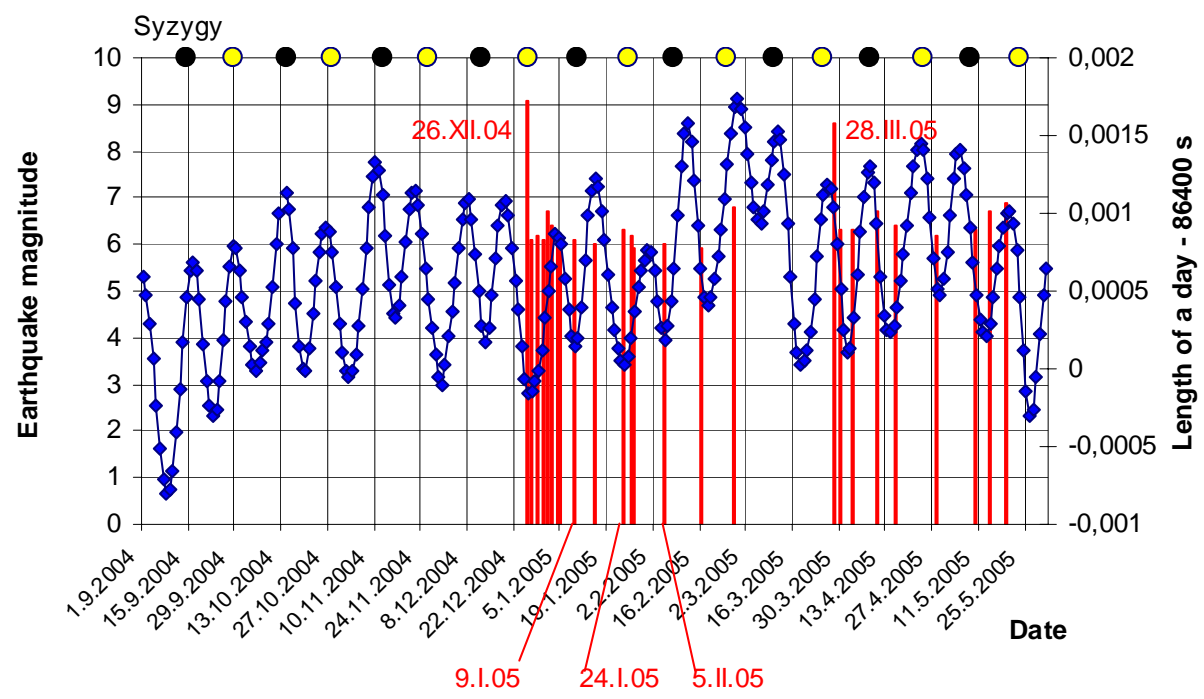

Fig. 3b. LOD record, syzygy and earthquakes of Sumatra and Andaman Sea over 6th magnitude including the Great Sumatra earthquake of 26 December 2004 M 9.1. Coincidences are evident of this earthquake with LOD minimum and with the full Moon. Aftershocks 9.I.2005, 24.I.2005 and 5.II.2005 coincide with LOD minimums. The earthquake 28.III.2005 was triggered 3 days after the full Moon but one day before LOD maximum. Following LOD maximum peak coincides with the new Moon exactly.

\section{Earth's rotation variations and earthquakes 2010-2011}

L. Ostřihanský

\section{Abstract}

Conclusions

\section{Tables}

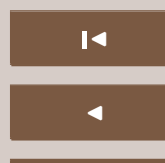

Back
Introduction

References

Figures

$\rightarrow$

\section{Close}

\section{Full Screen / Esc}

Printer-friendly Version

Interactive Discussion 


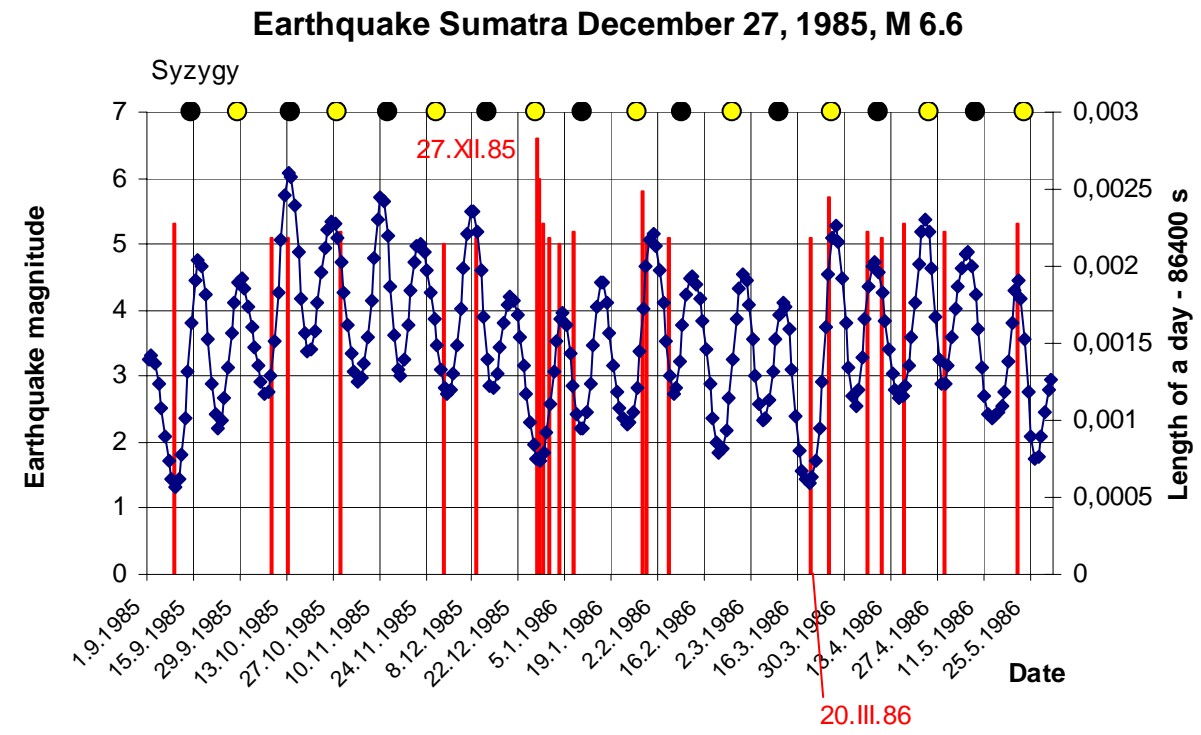

Fig. 3c. LOD record, syzygy and earthquakes of Sumatra and Andaman Sea over 5th magnitude including the earthquake of 27 December 1985. The similarity of this LOD record and the LOD record 19 years ago in Fig. $3 \mathrm{~b}$ is evident, and again there is coincidence of the earthquake with LOD minimum and the full Moon. The lowest LOD minimums 9.IX.1985 and 20.III.1986 coincide with earthquakes, however, without coincidence with syzygies.

\section{Earth's rotation variations and earthquakes 2010-2011}

L. Ostřihanský

\section{Abstract}

Conclusions

\section{Tables}

I

14

4

Back

Full Screen / Esc

Printer-friendly Version

Interactive Discussion 
Earthquakes coinciding with LOD maxima Dec. 9 and Dec. 23, 2009

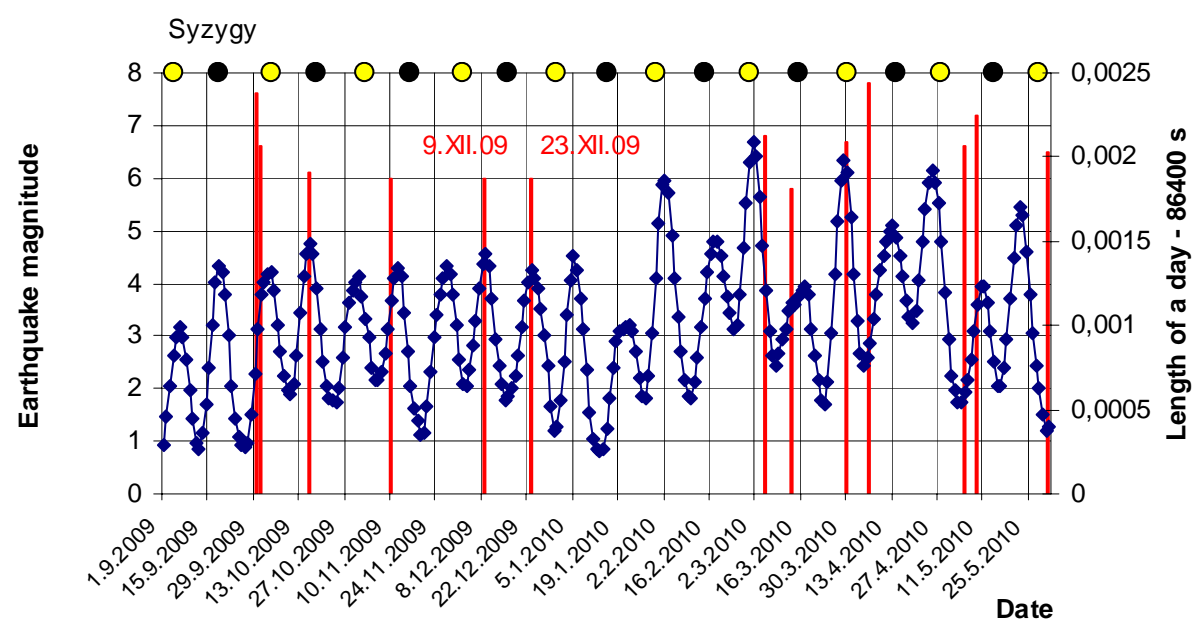

Fig. 3d. Figure 3d shows quite different LOD record from records on Fig. 3b,c, which is from the same area of the Sumatra and Andaman Sea covering earthquakes over 5.8 magnitude. Close to the solstice, two earthquakes 9.XII.2009 and 23.XII.2009 coincide with LOD maximums but in the last and first quarters between syzygy. This leads to a conjecture that also the low tides and resulting reversed pressure can trigger earthquake.

\section{Earth's rotation variations and earthquakes 2010-2011}

L. Ostřihanský

\section{Abstract}

Conclusions

\section{Tables}

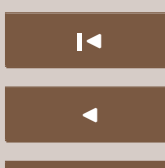

Back

\section{Full Screen / Esc}

Printer-friendly Version

Interactive Discussion 


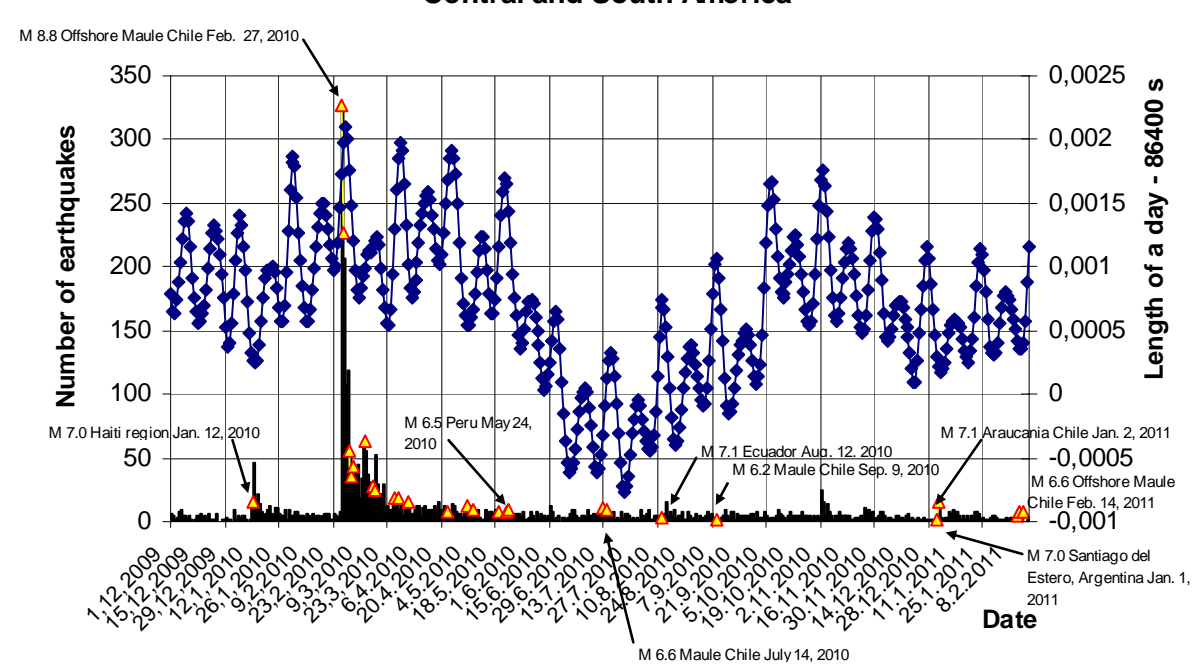

Fig. 4a. The LOD record showing the Earth's rotation acceleration during the Haiti 7.0 magnitude earthquake of 12 January 2010 and the Earth's rotation deceleration during the Maule Chile 8.8 magnitude earthquake of 27 February 2010. Other Earth's decelerations triggered earthquakes M 7.1 Ecuador, 12 August 2010 (depth $106 \mathrm{~km}$ ) and the earthquake M 6.2 in vicinity of Maule Chile earthquake (50 km on the south) at depth $16 \mathrm{~km}$ on 9 September 2010. Both these earthquakes coincide exactly with maximums of LOD record. Earthquakes are taken from NEIC, rectangle $25^{\circ} \mathrm{N}-50^{\circ} \mathrm{S}, 60-80^{\circ} \mathrm{W}$. Magnitudes over 6 are marked by triangles. (See four negative LOD amplitudes before the Haiti earthquake triggering).

\section{Earth's rotation variations and earthquakes 2010-2011}

L. Ostřihanský

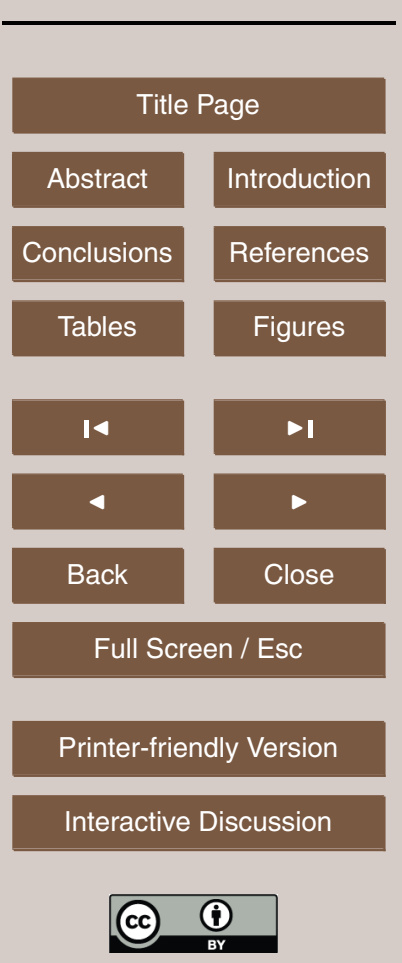




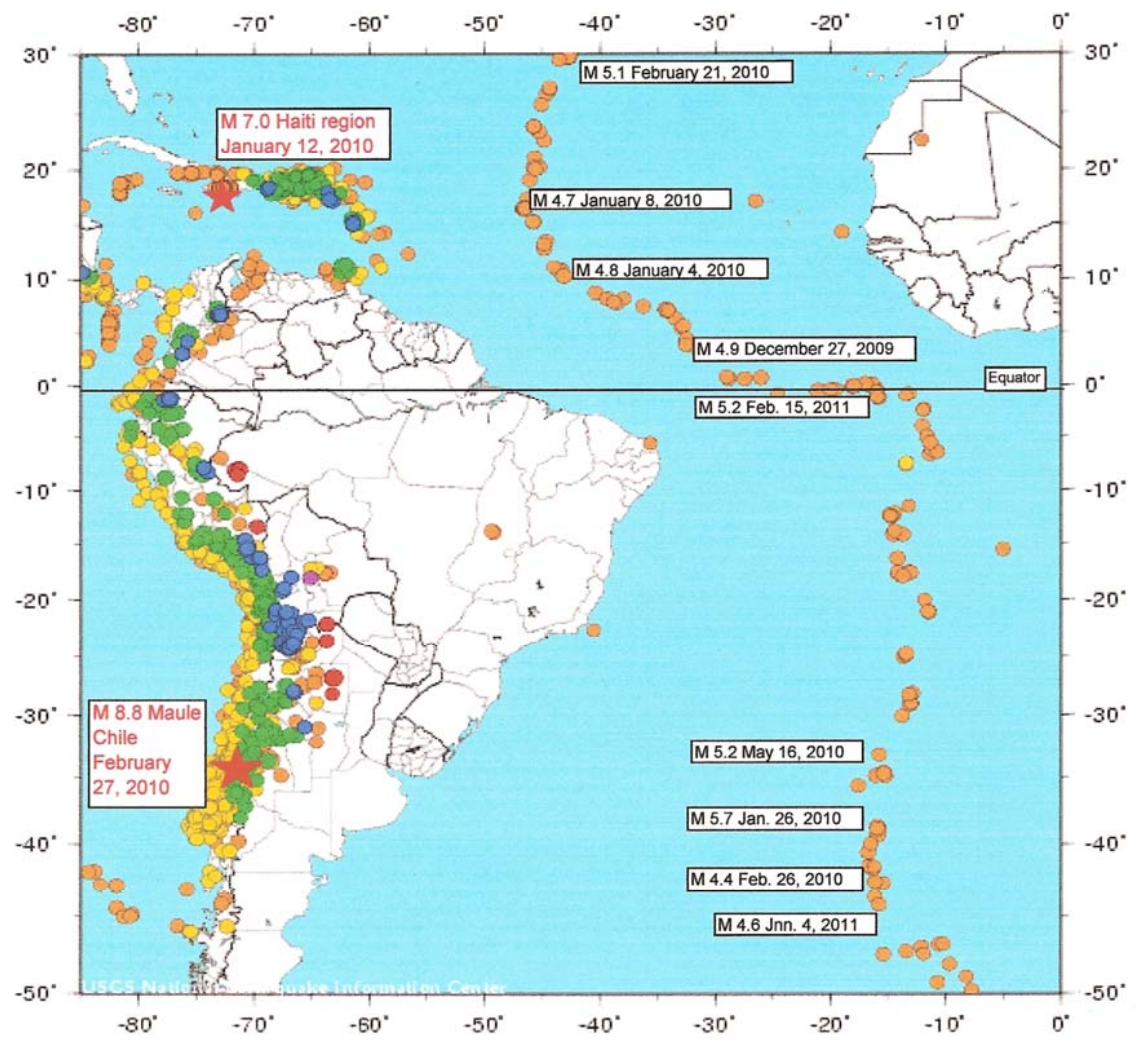

SED

4, 33-130, 2012

\section{Earth's rotation variations and earthquakes 2010-2011}

L. Ostřihanský

\section{Title Page}

Abstract

Conclusions

\section{Tables}

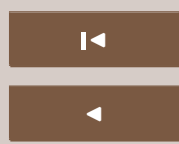

Fig. 4b. shows positions of Haiti and Maule Chile earthquakes in 2010 and situation of the Mid-Atlantic Ridge, originally of N-S direction, but shifted over equator in Northern Hemisphere by quick movement of the North American plate westward.
Back

Full Screen / Esc

Introduction

References

Figures

$\rightarrow$ I

$>$

Close

Printer-friendly Version

Interactive Discussion 
Haiti region + Mid-Atlantic Ridge

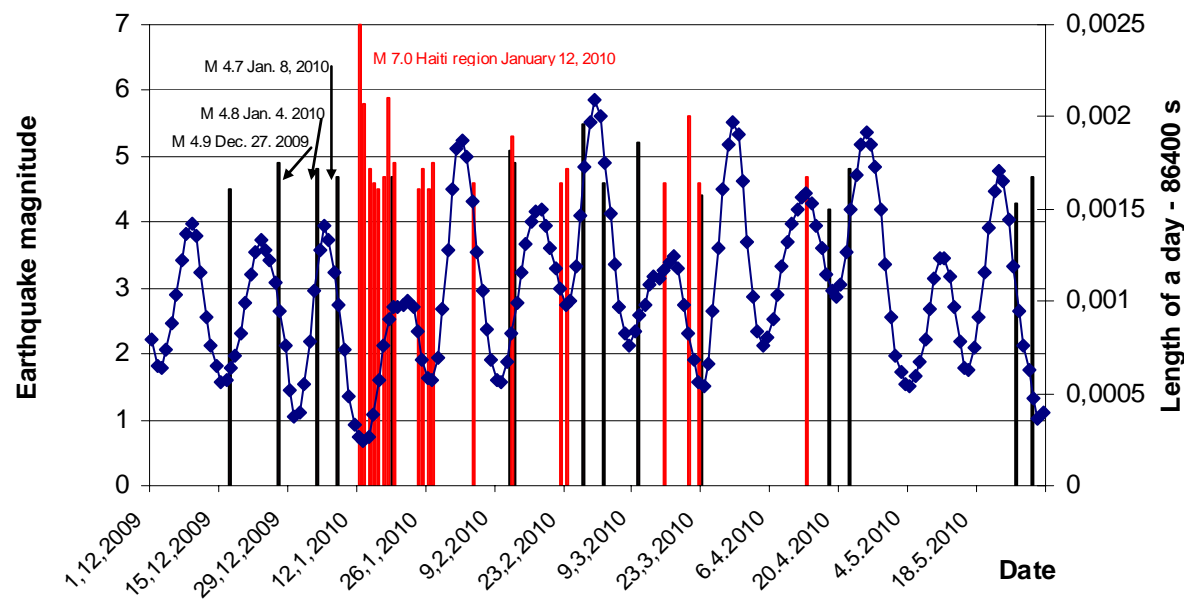

Fig. 4c. Earthquakes in Mid-Atlantic Ridge (black bars) triggered close to inflection points of LOD record consequently on ascending (decelerating) and descending (accelerating) branch, creating pressure on the North American plate. Earthquakes in transform fault of Haiti earthquakes (red bars) were triggered at the moment of LOD minimum, i.e. when the extreme pressure of Earth's rotation was released and the Earth's rotation started to decelerate.

\section{Earth's rotation variations and earthquakes 2010-2011}

L. Ostřihanský

\section{Abstract}

Conclusions

\section{Tables}

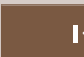

14

4

Back

\section{Full Screen / Esc}

Printer-friendly Version

Interactive Discussion 


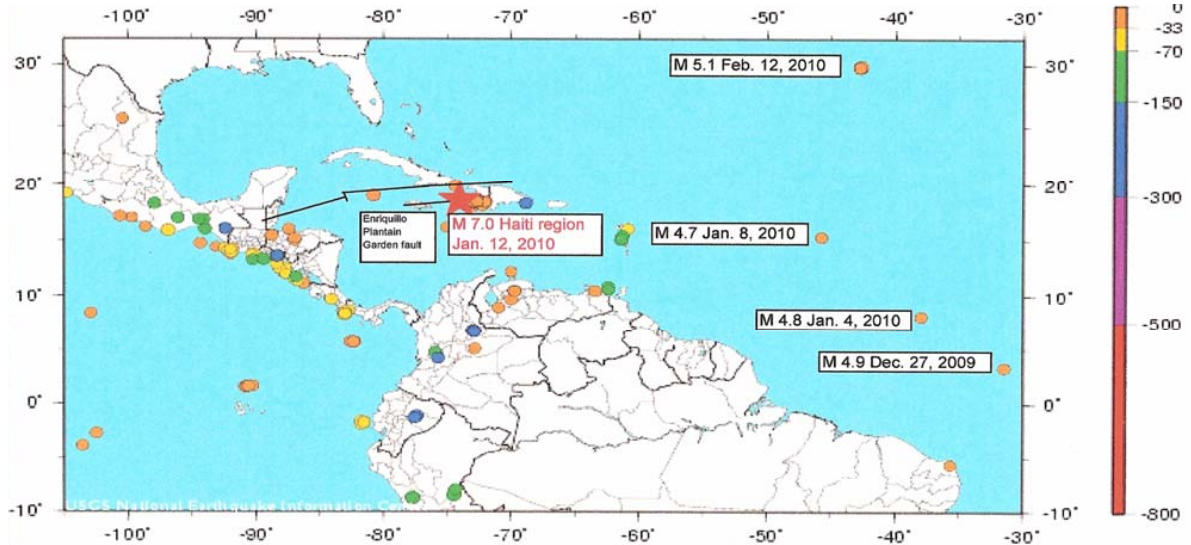

Fig. 4d. Figure 4d shows how earthquakes in Mid-Atlantic ridge have occurred consequently from equator northward. Shortly after the triggering of the earthquake on the most western rim of Mid-Atlantic Ridge on 8 January 2010 M 4.7, the Haiti earthquake 12 January 2010 M 7.0 was triggered.
Earth's rotation variations and earthquakes 2010-2011

L. Ostřihanský

\section{Abstract}

Conclusions

Tables

14

Back

Full Screen / Esc

Printer-friendly Version

Interactive Discussion 


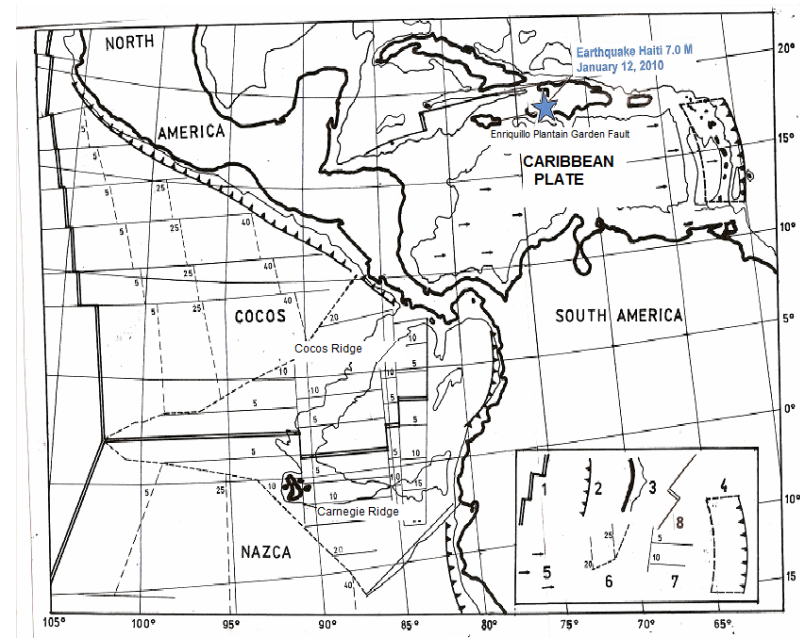

Fig. 4e. Position of the Haiti earthquake M 7.0 of 12 January 2010 on the transform fault (leftlateral stroke slip faulting on northern side of the Caribbean plate, Enriquillo-Plantain Garden fault system) (USGS Poster, 2010), separating the North and South American plates.

The Caribbean plate as a cut-out in oceanic lithosphere and setting of the Galapagos Rift system between the Cocos and Nazca plates as a rupture of a narrow plate caused by the rolling mantle: 1 - spreading center, 2 - subduction zone, 3 - shoreline with $500 \mathrm{~m}$ isobath, 4 - subduction zone and the schematic contour of submerged plate, 5 - direction of the rolling mantle, 6 - isochrones in M.Y. on the Nazca and Cocos plates, 7 - isochrones from the Galapagos rift (Hey and Vogt, 1977), 8 - transform faults.

For formation of the Cocos and Nazca plates, a better image than the westward movement of the American plate is that the Cocos and Nazca plates are firmly connected to mantle and rotating mantle, drifting them beneath the American plate and causing their rupture. Fixed Galapagos hotspot forms two hotspsot tracks on the both sides the rupture, forming Cocos and Carnegie Ridges created by consequent opening of the rupture.
SED

4, 33-130, 2012

\section{Earth's rotation variations and earthquakes 2010-2011}

L. Ostřihanský
Abstract

Conclusions

Tables

14

4

Back

\section{Introduction}

References

\section{Figures}

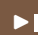

\section{Close}

Full Screen / Esc

Printer-friendly Version

Interactive Discussion 
Mid-Atlantic Ridge + Chile trench (detail)

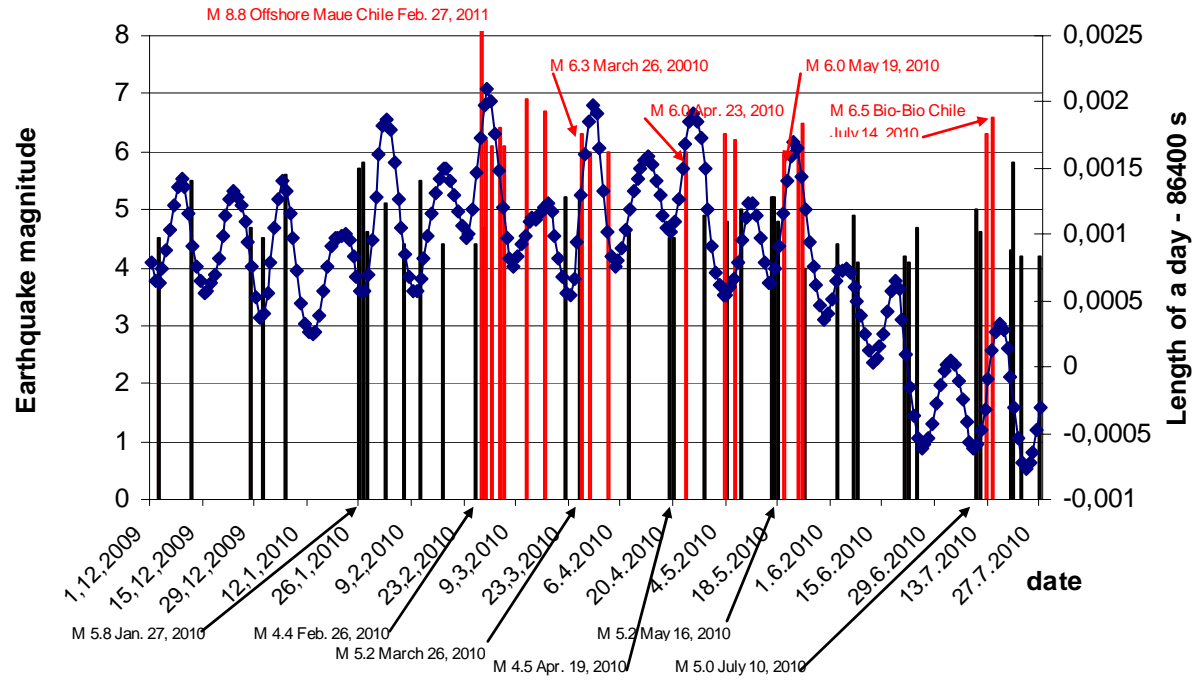

Fig. 4f. Increased LOD variations after the end of January 2010 caused earthquakes in the Mid-Atlantic Ridge (black bars) and earthquakes in Chile Trench subduction zone (red bars). In most cases earthquakes in Mid-Atlantic Ridge precede earthquakes in Chile Trench.

\section{Earth's rotation variations and earthquakes 2010-2011}

L. Ostřihanský

\section{Abstract}

Conclusions

\section{Tables}

14

4

Back

\section{Introduction}

References

\section{Figures}

$\Delta$

Close

\section{Full Screen / Esc}

Printer-friendly Version

Interactive Discussion 


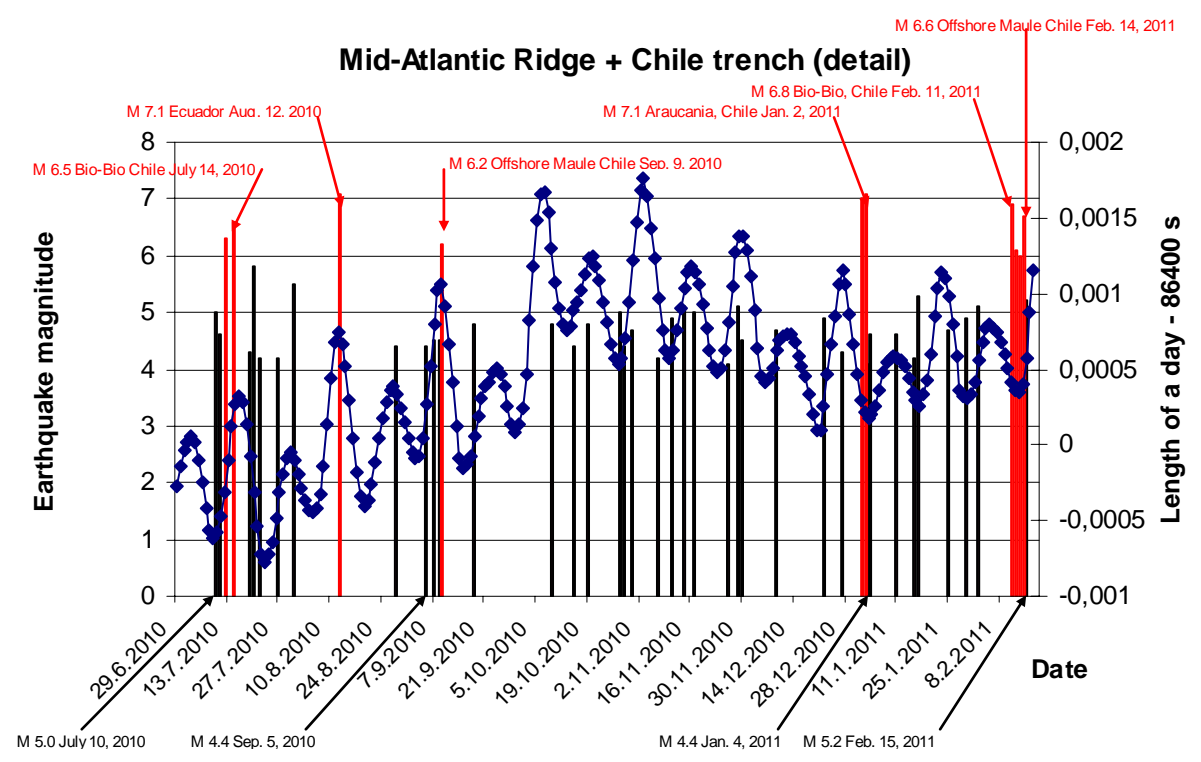

Fig. 4g. Earthquakes in summer 2010 coincide exactly with LOD maximum. After quiet period September-December 2010, at the beginning of year 2011 earthquakes of the Chile Trench occur in LOD minimum. This convinces about the release of the subduction zone. Earthquakes in subduction zone react first on Earth's variations in reverse mode (in LOD minimum), and then earthquakes in Mid-Atlantic Ridge occur.

\section{Earth's rotation variations and earthquakes 2010-2011}

L. Ostřihanský

\section{Abstract}

Conclusions

\section{Tables} I

is

4

Back

\section{Introduction}

References

Figures

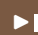

\section{Close}

\section{Full Screen / Esc}

Printer-friendly Version

Interactive Discussion 


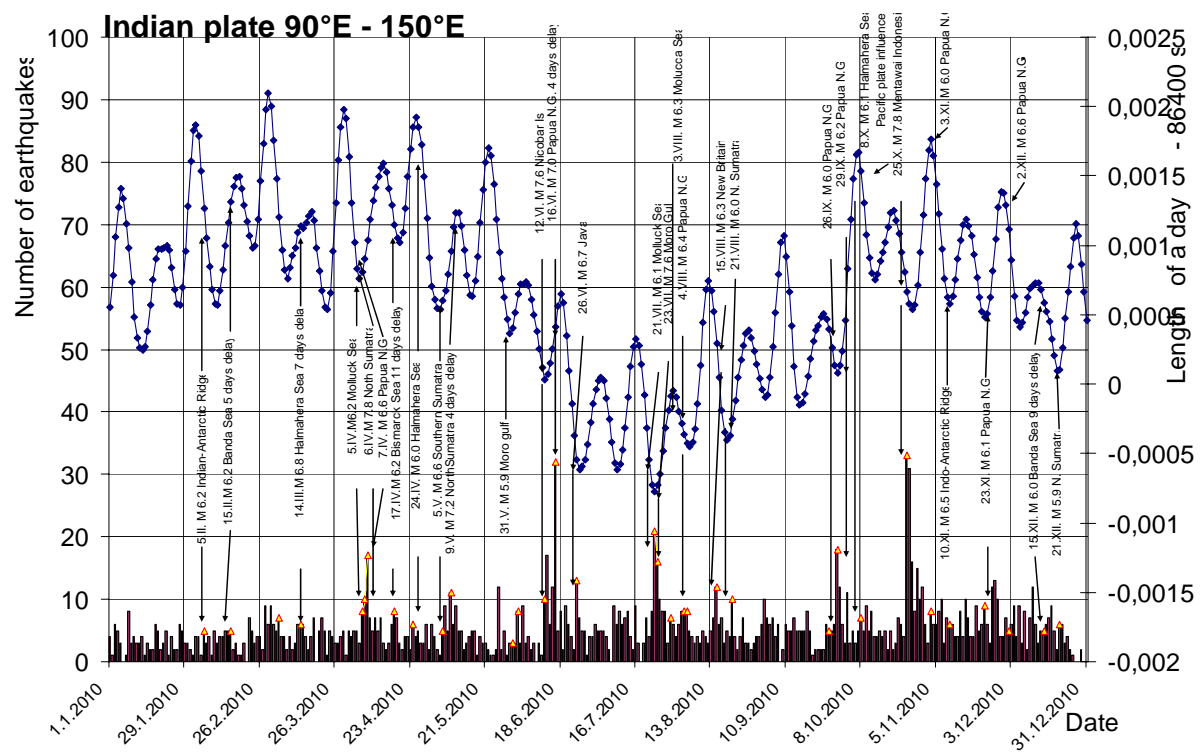

Fig. 4h. Earthquakes of the Indian plate in 2010. To avoid influence of earthquakes triggered by westward movement of the Pacific plate, only band $90-150^{\circ} \mathrm{E}$ was taken. Triangles mark earthquake $>$ M 6 .

\section{Earth's rotation variations and earthquakes 2010-2011}

L. Ostřihanský

\section{Title Page}

Abstract

Conclusions

\section{Tables}

14

4

Back

\section{Full Screen / Esc}

Printer-friendly Version

Interactive Discussion 
Southeast Indian Ocean Ridge + New Zealand earthquakes

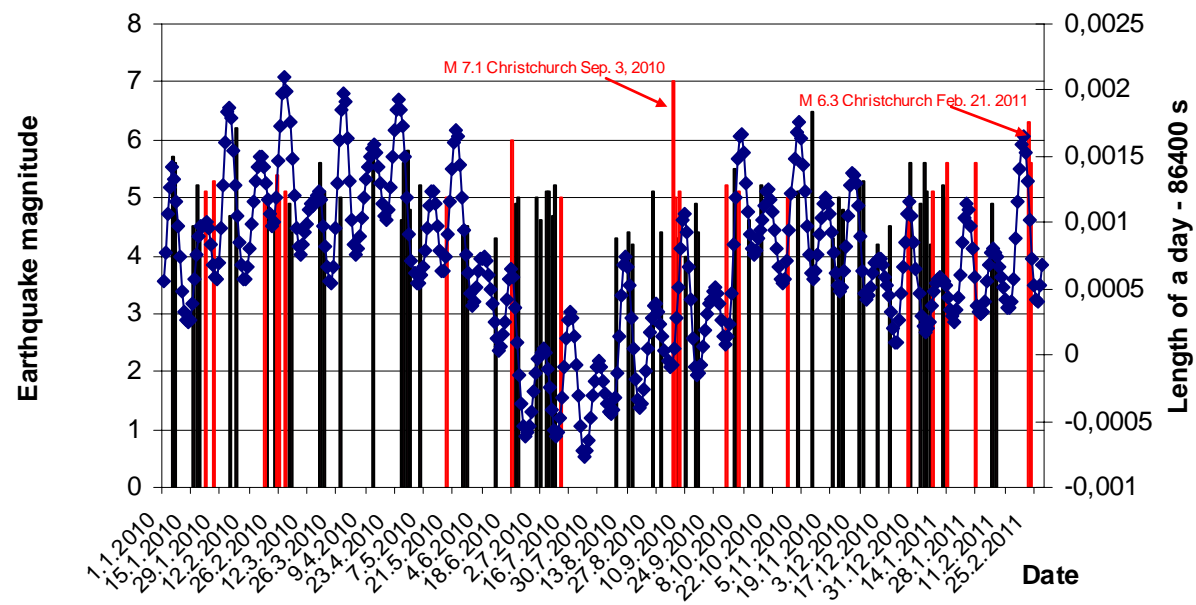

Fig. 4i. Earthquakes in N. Zealand region in 2010 till February 2011. The earthquake of Christchurch 3 September 2010 occurred in the second LOD minimum, as most of earthquakes in the Indian plate in autumn 2010. See 3 repetitions of this earthquake after 27.6 days. Disastrous earthquake Christchurch 21 February 2011 occurred in reciprocal cycles in LOD maximum.

\section{Earth's rotation variations and earthquakes 2010-2011}

L. Ostřihanský

\section{Abstract}

Conclusions

\section{Tables}

14

4

Back

\section{Introduction}

References

\section{Figures}

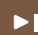

$\checkmark$

\section{Close}

\section{Full Screen / Esc}

Printer-friendly Version

Interactive Discussion 


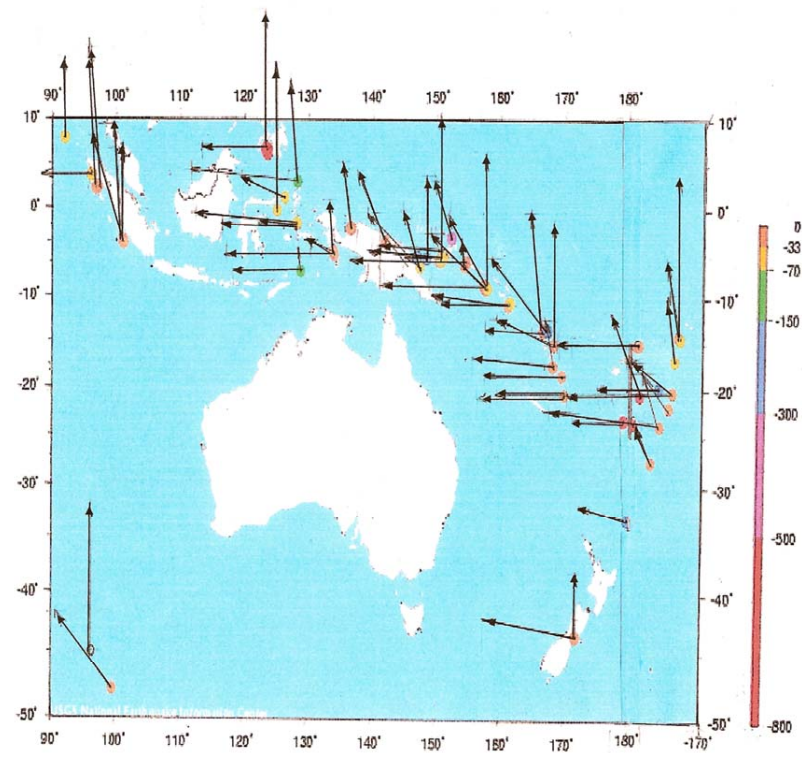

Fig. 4j. Construction of northward and westward movement of the Indian plate. Directions were measured from LOD graph back for 7 days after the earthquake. It means that earthquakes triggered exactly on LOD minimum were caused by northward movement. Those triggered on LOD maximum were caused by westward movement. Earthquakes between LOD extremes determined sections on ascending or descending branch (back in 7 days), which were added vectorially. Figure shows that most earthquakes on Sumatra were triggered on LOD minimum, with only one exception caused probably by delay. Earthquakes from Banda Sea direct westward similarly to subduction zone on that site. Earthquakes in LOD small maximum between 28 days maximums show that those earthquakes were probably delayed. For those the area on the west from N. Guinea is typical.

Earthquakes on the north rim are triggered on the LOD minimum. Most earthquakes from Banda Sea, N. Hebrides, Kermadek and Tonga direct westward.
4, 33-130, 2012

\section{Earth's rotation variations and earthquakes 2010-2011}

L. Ostřihanský

\section{Abstract}

Conclusions

\section{Tables}

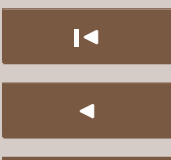

Back

\section{Introduction}

References

\section{Full Screen / Esc}

Printer-friendly Version

Interactive Discussion 


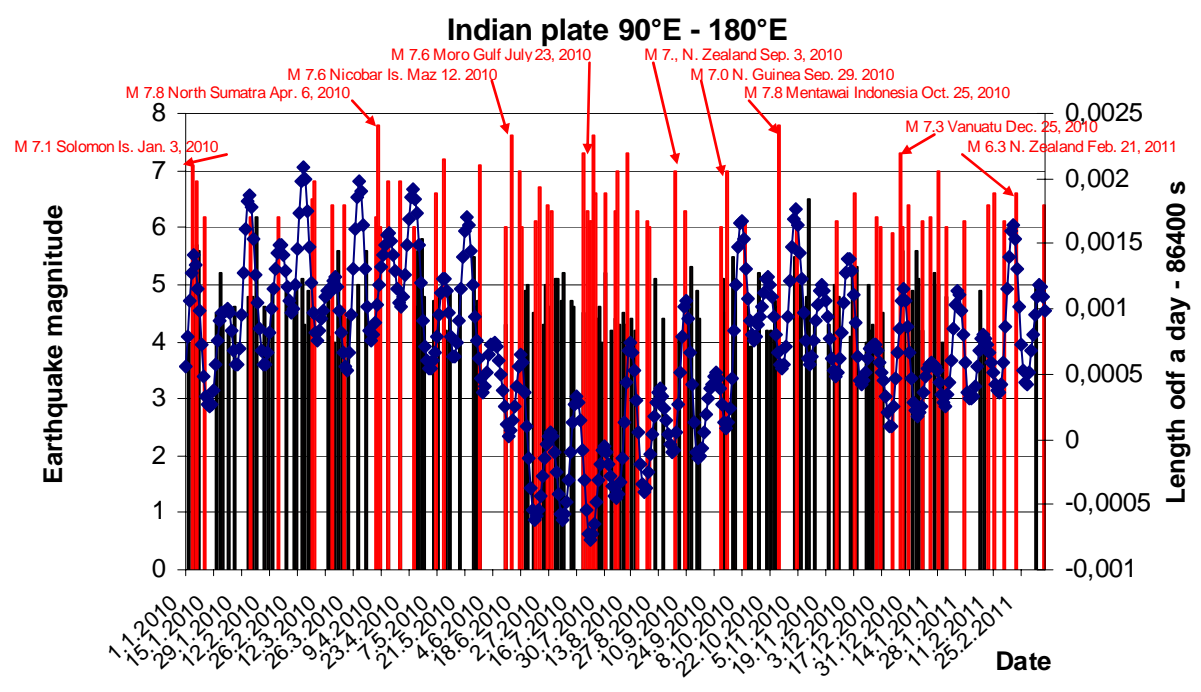

Fig. 4l. shows comparison of Indian plate earthquakes > M 6 (red bars) and earthquakes on the Southeast Indian Ocean Ridge (black bars) separating the Indian plate from Antarctica. The large number of earthquakes in summer LOD minimum is evident.

\section{Earth's rotation variations and earthquakes 2010-2011}

L. Ostřihanský

Title Page
Abstract

Conclusions

Tables

14

4

Back
Introduction

References

Figures

$\Delta$

$>$

\section{Close}

Full Screen / Esc

Printer-friendly Version

Interactive Discussion 
Southeast Indian Ocean Ridge + Indian plate earthquakes

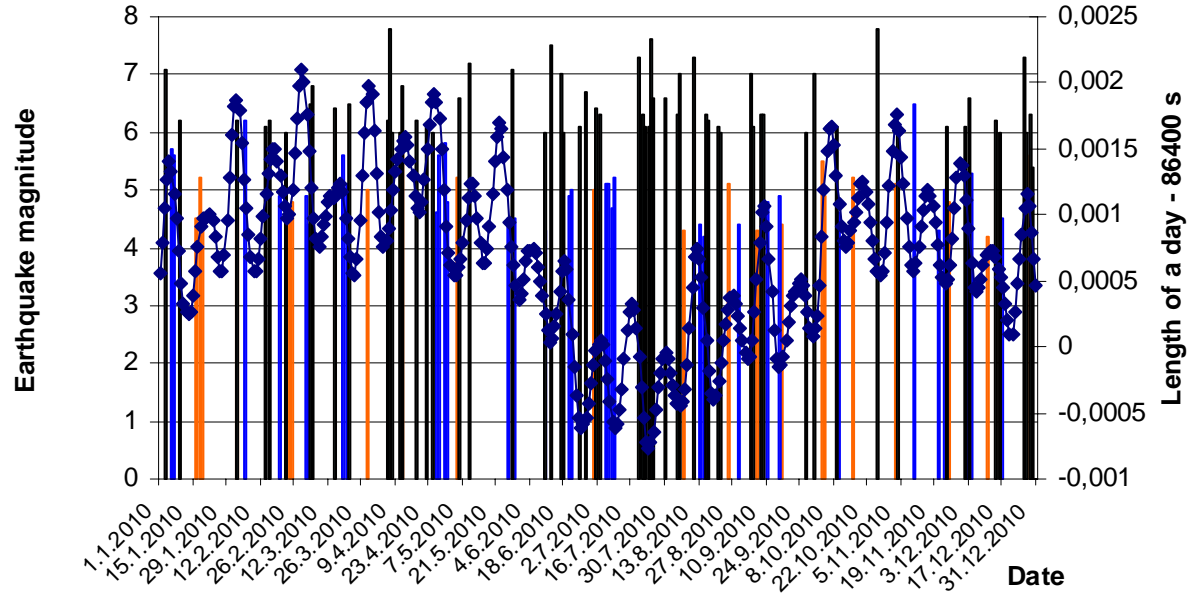

Fig. 4m. Earthquakes in Southeast Indian Ocean Ridge show differences whether they are on descending LOD branch (blue bars - 33 earthquakes) or ascending branch (orange bars - only 22 earthquakes). This shows that there is force acting during the Earth's acceleration, pushing the Indian plate northward.
Earth's rotation variations and earthquakes 2010-2011

L. Ostřihanský

\section{Abstract}

Conclusions

Tables

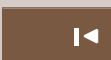

\section{4}

Back

\section{Introduction}

References

\section{Figures}

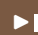

\section{Close}

Full Screen / Esc

Printer-friendly Version

Interactive Discussion 


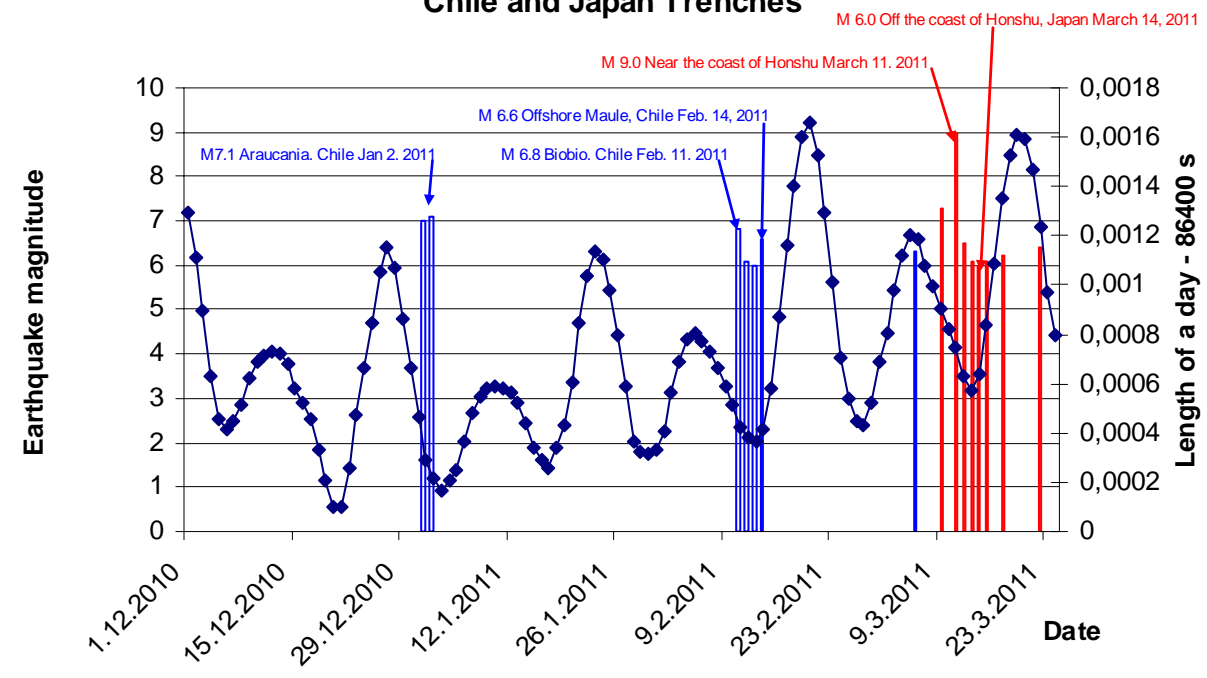

\section{Earth's rotation variations and earthquakes 2010-2011}

L. Ostřihanský

Fig. 5a. The LOD record and earthquakes in Japan and Chile at the beginning of 2011. Seemingly incoherent earthquakes in Chile Trench (blue bars) and Japan Trench (red bars) over M 6 were triggered by the second LOD minimum (Earth's rotation increment) but in Chile Trench one month (exactly 27.32 days) sooner. Supposing the continental lithosphere of the South American and Eurasian plates fixed in GPS satellite system, then the mantle beneath rotates during the Earth's rotation increment eastward. Rotating mantle drags the Nazca plate down the Chile Trench and the oceanic lithosphere of the Pacific plate moves away from Japan. At the same time it drags the continental lithosphere of Northern Honshu 8 feet $(\sim 2.44 \mathrm{~m})$ eastward.

\section{Title Page}

\section{Abstract}

Introduction

Conclusions

References

Tables

Figures

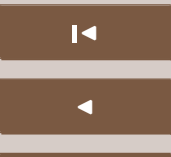

$\rightarrow 1$

Back

Close

Full Screen / Esc

Printer-friendly Version

Interactive Discussion 


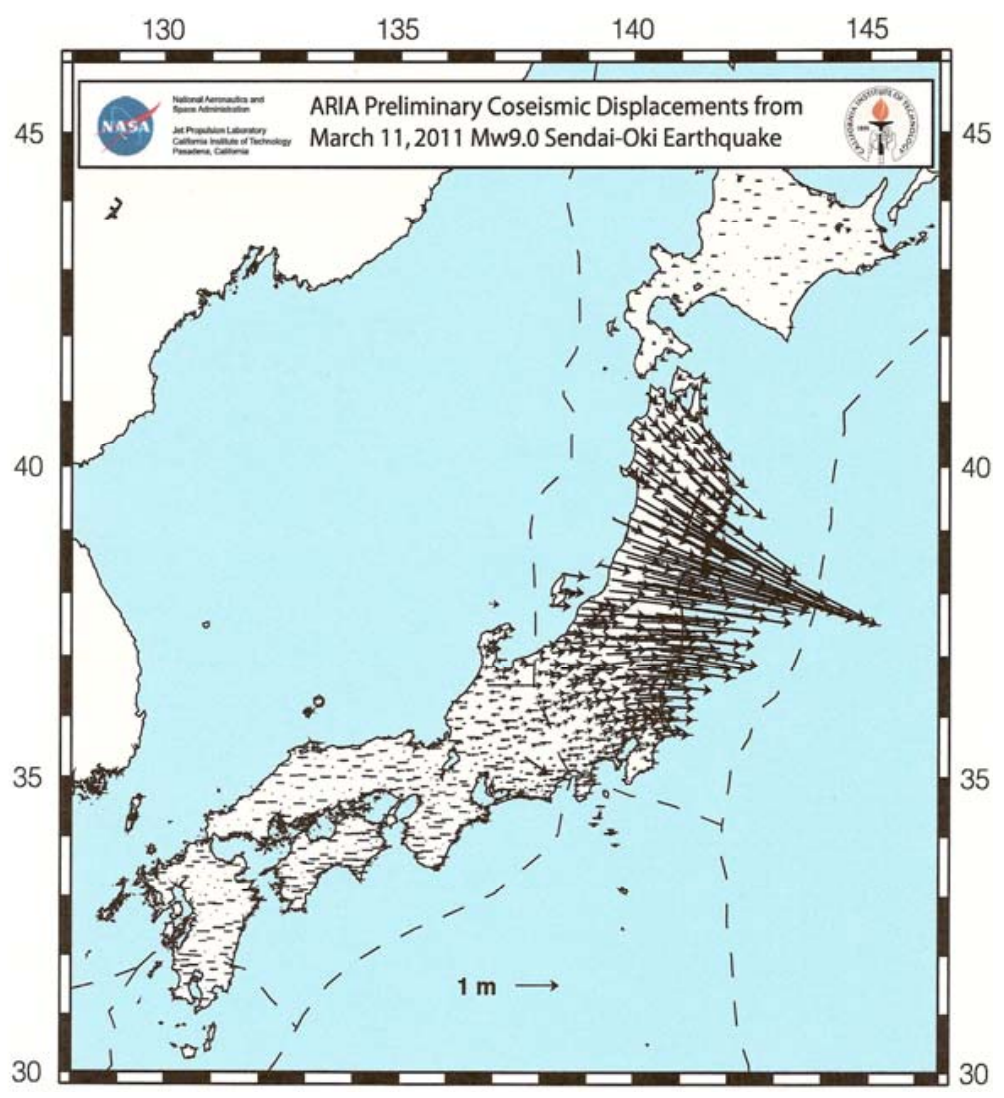

Fig. 5b. GPS horizontal movement of Northern Honshu (NASA 2011). Honshu was dragged by the rolling mantle out from the continental lithosphere of Eurasian plate.
SED

4, 33-130, 2012

Earth's rotation variations and earthquakes 2010-2011

L. Ostřihanský

Title Page
Abstract

Conclusions

Tables

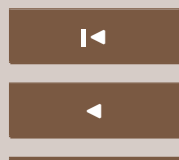

Back

\section{Full Screen / Esc}

Printer-friendly Version

Interactive Discussion 


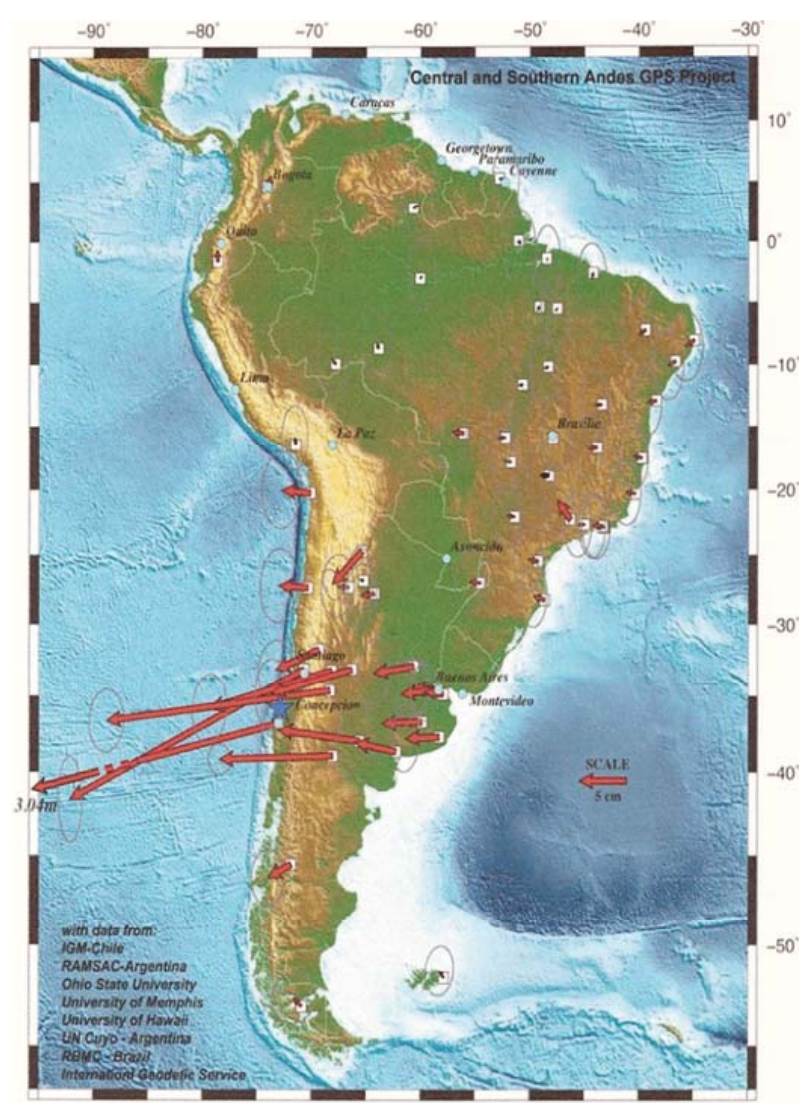

Fig. 6. The movement of South American continent during the magnitude 8.8 - offshore Maule Chile earthquake and the $3.04 \mathrm{~m}$ westward jump of the continent in the city of Concepcion after the earthquake. Read more (Report from Wired Science 2010). http://www. wired.com/wiredscience/2010/03/chile-earthquake-moved-entire-city-10-feet-to-the-west/ \#ixzz0hr4xF7ZM

\section{SED}

4, 33-130, 2012

Earth's rotation variations and earthquakes 2010-2011

L. Ostřihanský

\section{Title Page}

\section{Abstract}

Conclusions

\section{Tables}

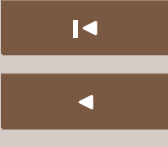

Back
Introduction

References

\section{Full Screen / Esc}

Printer-friendly Version

Interactive Discussion 
Earthquake histogram Sumatra and Andaman Sea 1963-2011 earthquake occurrece before and after the full or new Moon

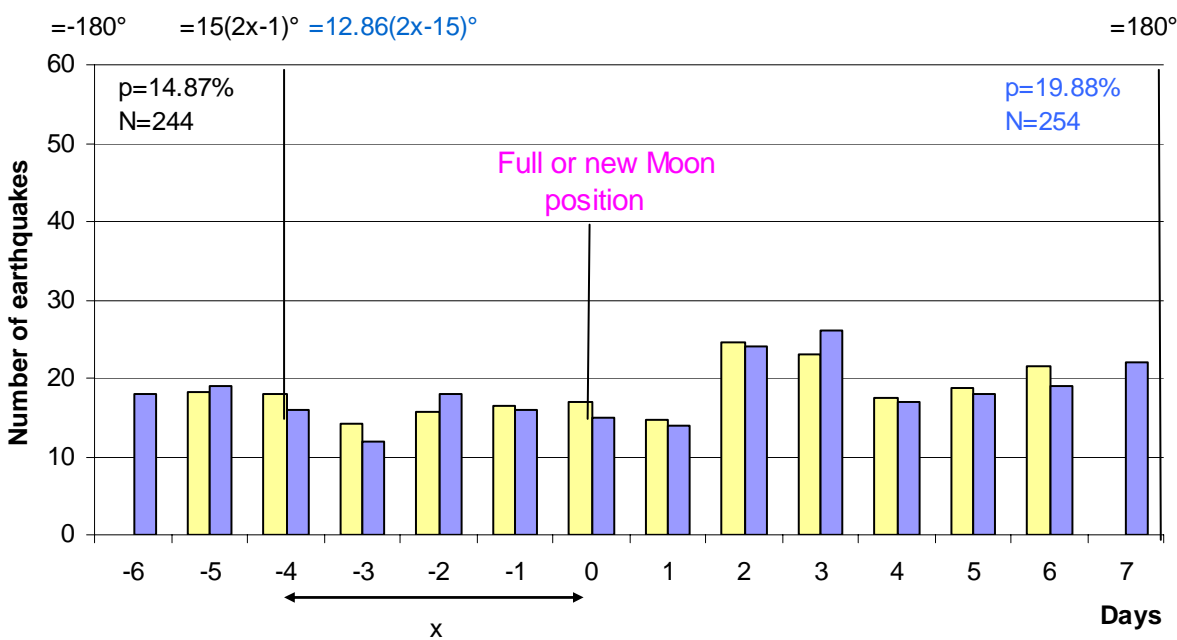

Fig. 7a. Histogram of earthquake occurrence in days before and after the full or new Moon for 14 and 12-interval distribution. Transformation formulas from days $x$ to phase angle $\varphi$ for the Schuster's test are given above.

\section{Earth's rotation variations and earthquakes 2010-2011}

L. Ostřihanský

\section{Title Page}

\section{Abstract}

Conclusions

\section{Tables}

14

4

Back
Introduction

References

Figures

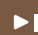

$>$

\section{Close}

\section{Full Screen / Esc}

Printer-friendly Version

Interactive Discussion 


\section{Earthquake histogram Sumatra and Andaman sea 1963-2011}

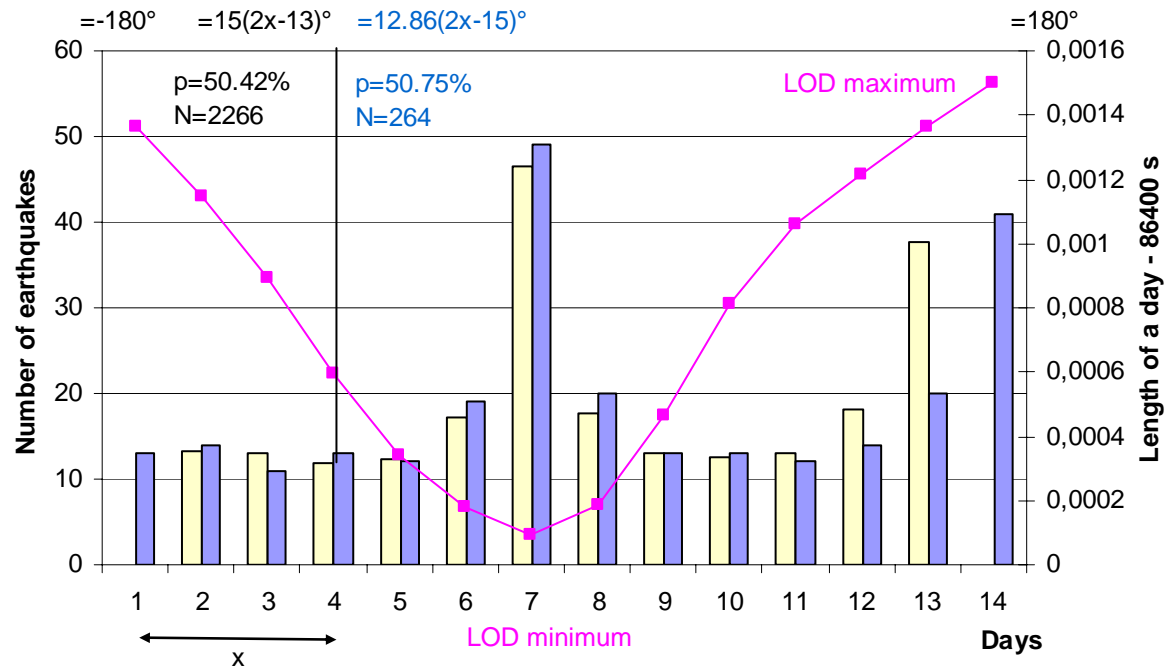

Fig. 7b. Histogram for earthquake occurrence during the 13.66 days sidereal Earth's rotation cycle. Owing to distinctive earthquake occurrences in LOD minimum and LOD maximum, the Schuster's test gives very high value of the parameter $p$ over $50 \%$. Separating the 13.66 days histogram into two 8-interval histograms along descending and ascending LOD graph braches, result gives $p=0.000059 \%$ for descending branch and $p=0.0016 \%$ for ascending branch, Fig. 7b1,b2. 8-interval histogram in LOD minimum gives $p=0.000073 \%$ and symmetric random distribution of earthquakes, Fig. $7 \mathrm{~b} 3$. Figure $7 \mathrm{~b} 4$ for LOD maximum gives partly asymmetric earthquake distribution and $p=0.010 \%$.

\section{Earth's rotation variations and earthquakes 2010-2011}

L. Ostřihanský

\section{Abstract}

Conclusions

\section{Tables} I

\section{Back}

\section{Full Screen / Esc}

Printer-friendly Version

Interactive Discussion 
Eathquake histogram Sumatra and Andaman Sea 1963-2011 on LOD descending branch

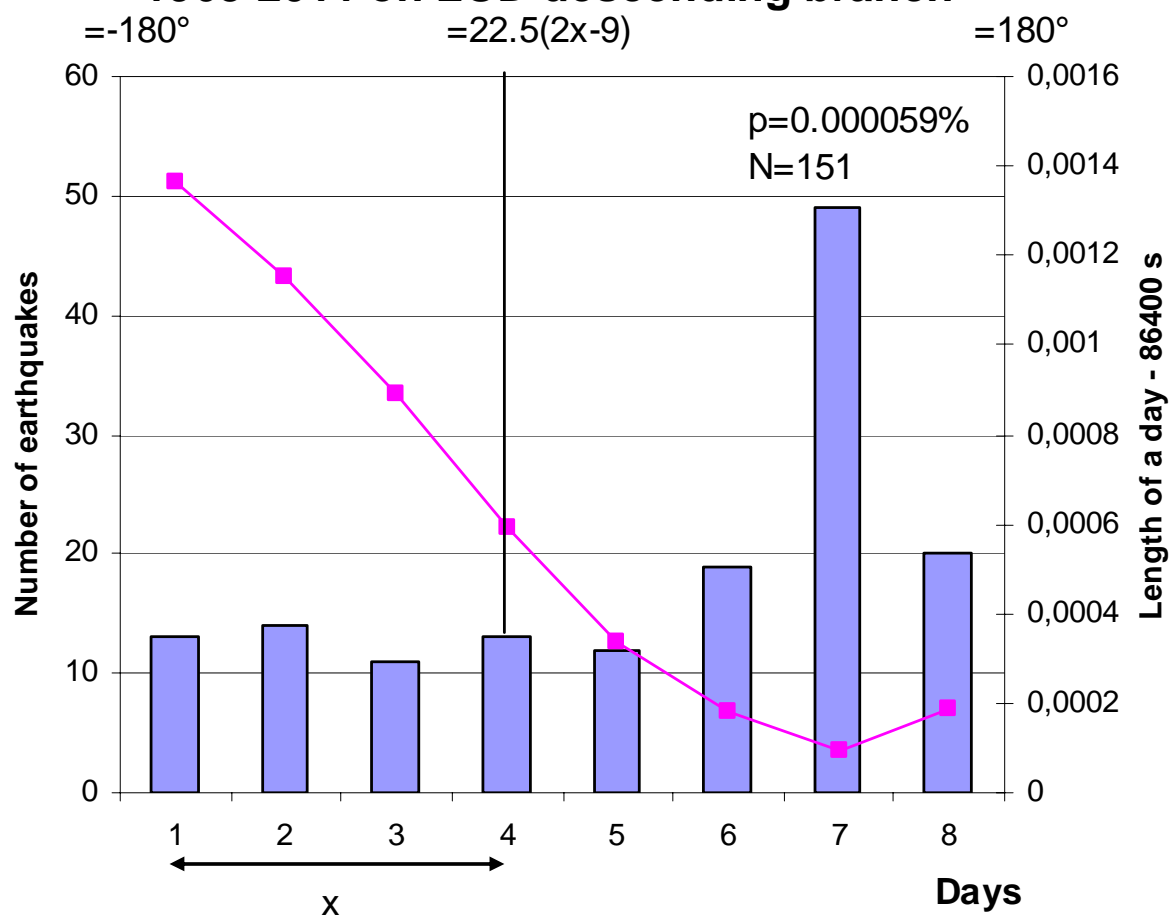

Fig. 7b1. Continued.
SED

4, 33-130, 2012

Earth's rotation variations and earthquakes 2010-2011

L. Ostřihanský

\section{Abstract}

Conclusions

Tables

14

4

Back

\section{Full Screen / Esc}

Printer-friendly Version

Interactive Discussion 


\section{Earthquake histogram Sumatra and Andaman Sea}

1963-2011 on LOD ascending branch

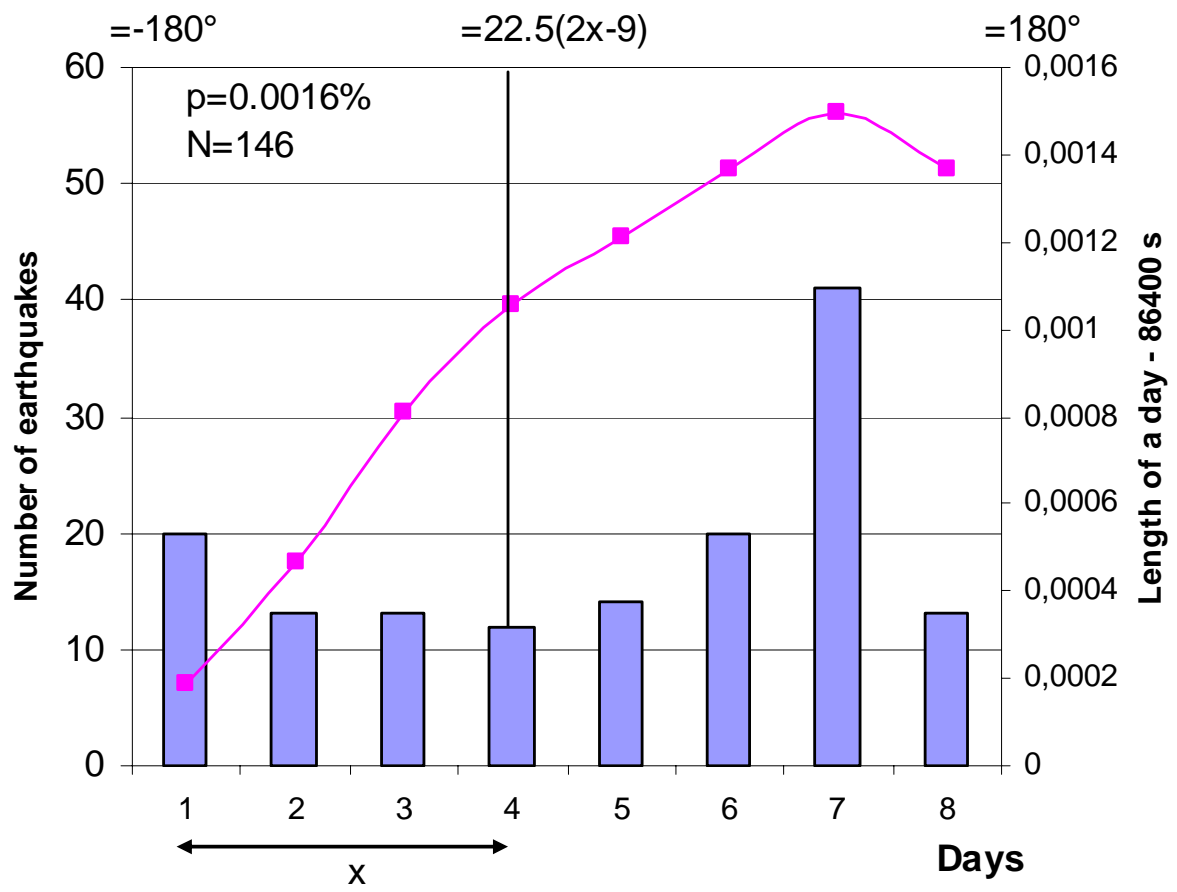

SED

4, 33-130, 2012

Earth's rotation variations and earthquakes 2010-2011

L. Ostřihanský

Title Page

Abstract

Conclusions

Tables

14

4

Back

Full Screen / Esc

Printer-friendly Version

Interactive Discussion 


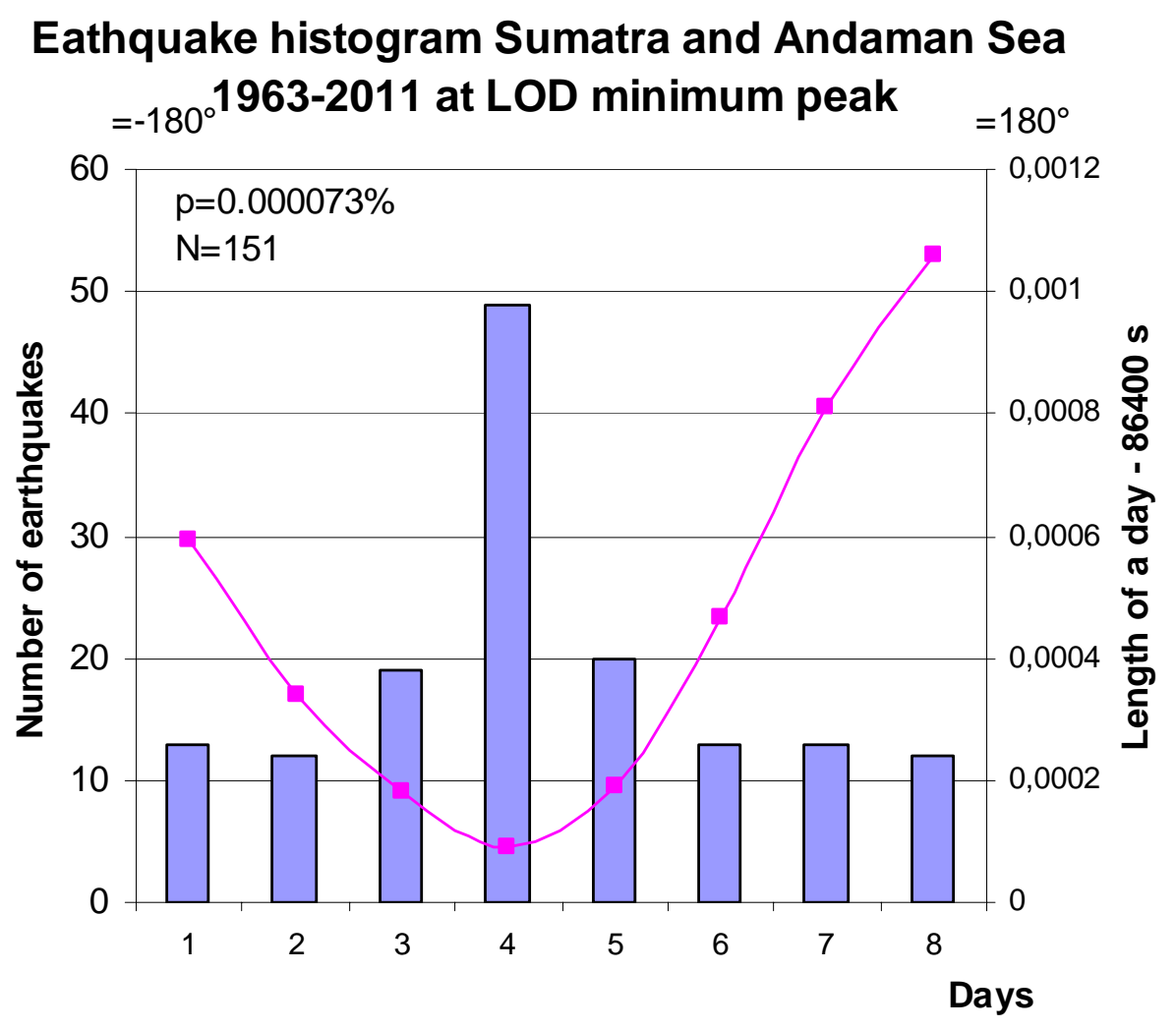

4, 33-130, 2012

Earth's rotation variations and earthquakes 2010-2011

L. Ostřihanský

Title Page

Abstract

Conclusions

Tables

14

4

Back

Full Screen / Esc

Printer-friendly Version

Interactive Discussion 


\section{Eathquake histogram Sumatra and Andaman Sea} 1963-2011 at LOD maximum peak

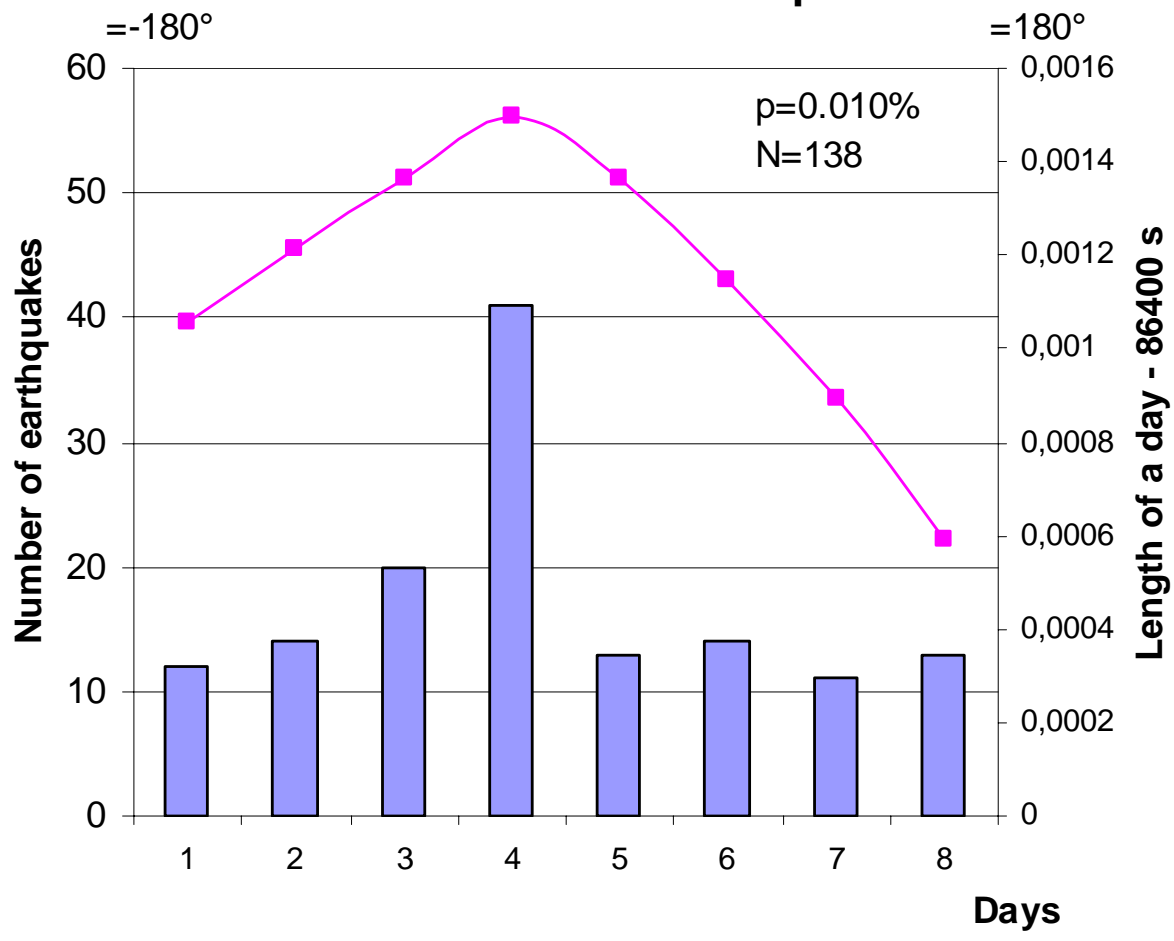

Fig. 7b4. Continued.

\section{SED}

4, 33-130, 2012

Earth's rotation variations and earthquakes 2010-2011

L. Ostřihanský

\section{Abstract}

Conclusions

Tables

14

4

Back

\section{Full Screen / Esc}

Printer-friendly Version

Interactive Discussion 


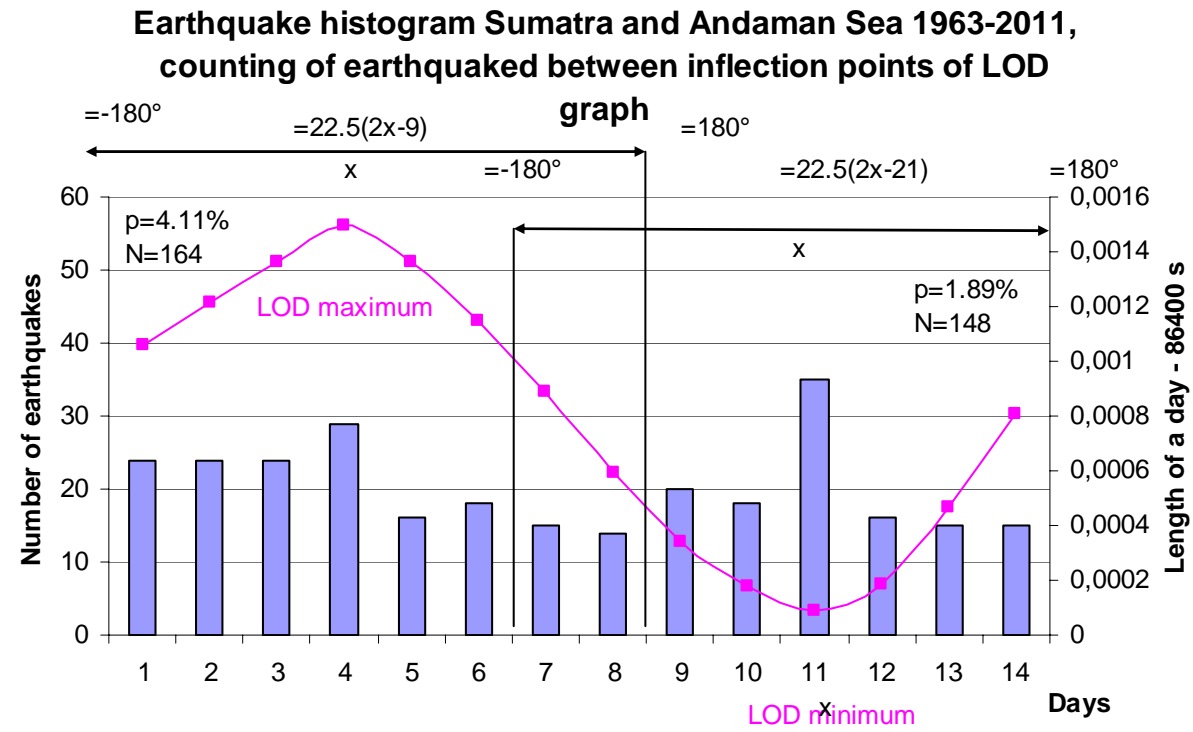

Fig. 7c. Counting earthquakes in days can be also performed from inflection points of LOD graph. This gives less accurate number of earthquakes in LOD extremes and more earthquakes in days before extremes. Counting earthquakes from fixed extremes is recommended because the LOD graph is influenced by many factors, but extremes are decisive for triggering of earthquakes.

\section{Earth's rotation variations and earthquakes 2010-2011}

L. Ostřihanský

\section{Abstract}

Conclusions

\section{Tables}

I

14

4

Back

Full Screen / Esc

Printer-friendly Version

Interactive Discussion 


\section{Earthquake histogram Southeast Indian Ocean Ridge} 2008-2011

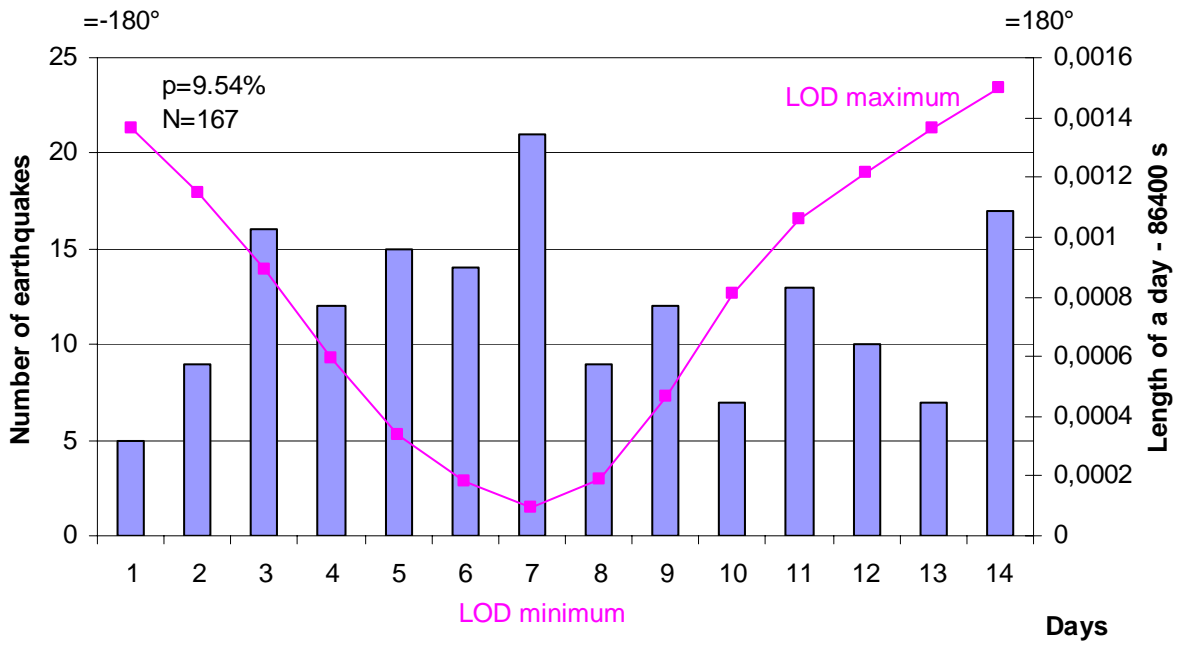

Fig. 7d. Histogram of earthquakes from the South Indian Ocean Ridge shows maximums in LOD extremes, but owing to the movement of the Indian plate northward, there is the increased number of earthquakes in descending (accelerating) branch of LOD record; i.e. more earthquakes are in the moving plate than in the stable one. Detailed 8-interval histograms Fig. 7d1, d2 confirms this. Descending branch $p=5.89 \%$ is close to the random distribution with earthquake maximum in LOD minimum, but the ascending branch has irregular distribution $p=87.90 \%$.
4, 33-130, 2012

\section{Earth's rotation variations and earthquakes 2010-2011}

L. Ostřihanský

\section{Title Page}

\section{Abstract}

Introduction

Conclusions

References

Tables

Figures
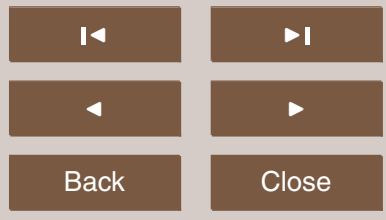

Back

Full Screen / Esc

Printer-friendly Version

Interactive Discussion 


\section{Earthquake histogram Southeast Indian Ocean Ridge} 2008-2011 on LOD descendig branch

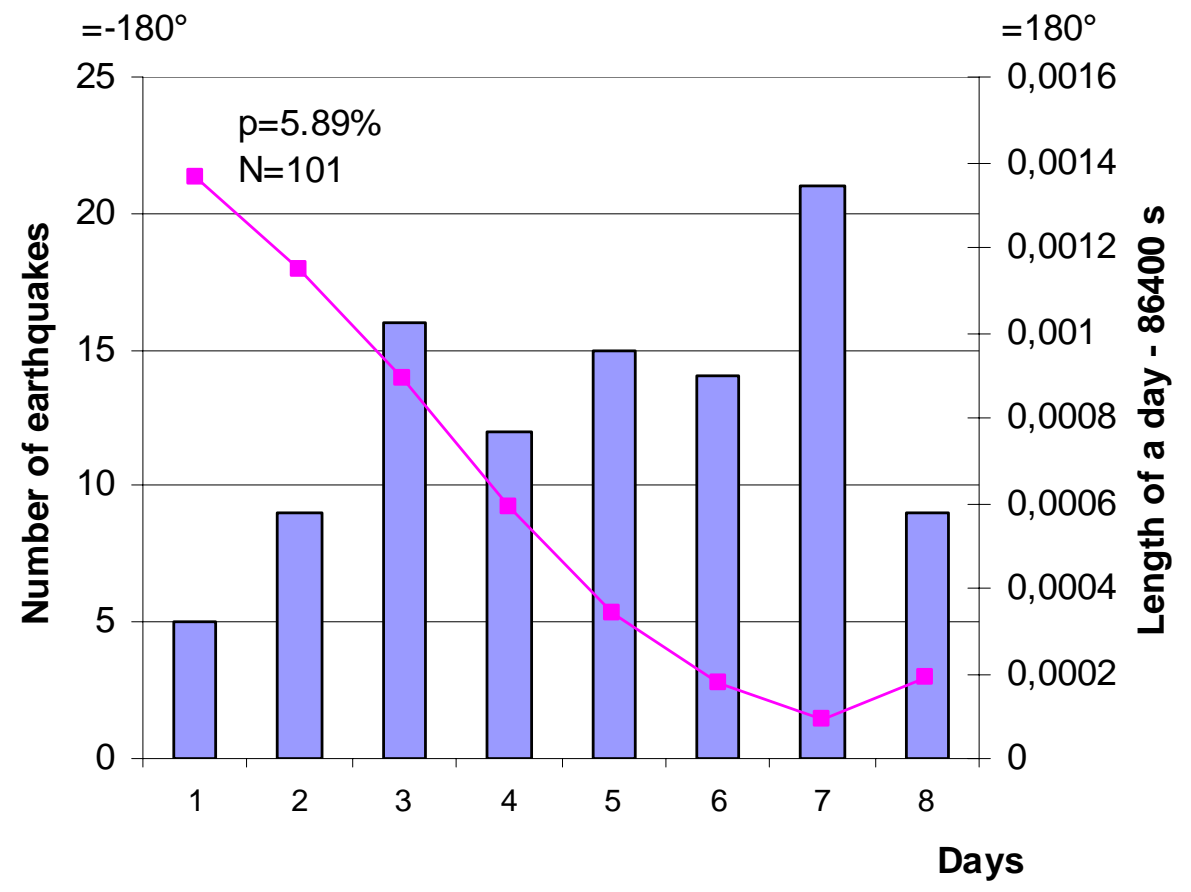

Fig. 7d1. Continued.
SED

4, 33-130, 2012

Earth's rotation variations and earthquakes 2010-2011

L. Ostřihanský

Title Page
Abstract

Conclusions

Tables

14

4

Back
Introduction

References

Figures

$\Delta$

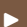

Close

\section{Full Screen / Esc}

Printer-friendly Version

Interactive Discussion 
Earthquake histogram Southeast Indian Ocean Ridge 2008-2011 on LOD ascending branch

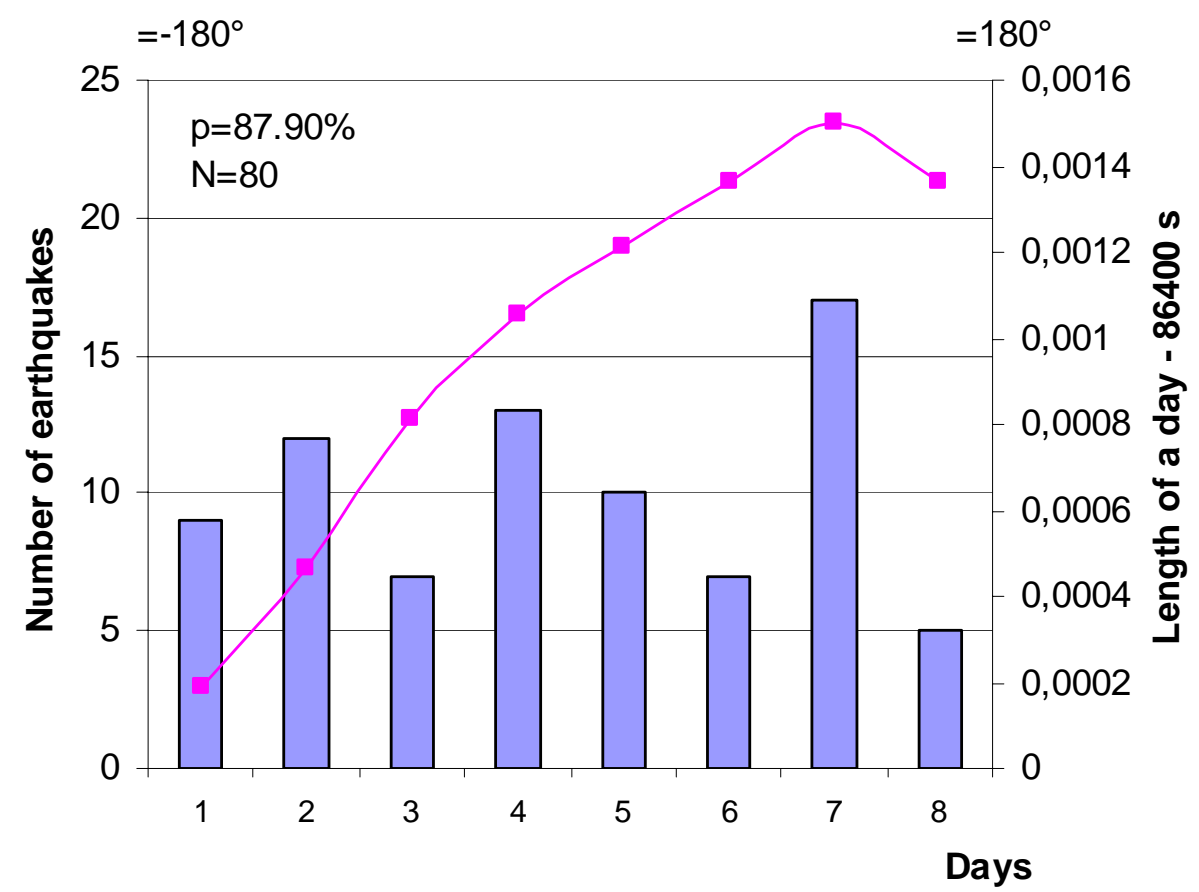

Fig. 7d2. Continued.
SED

4, 33-130, 2012

Earth's rotation variations and earthquakes 2010-2011

L. Ostřihanský

Title Page
Abstract

Conclusions

Tables

14

4

Back
Introduction

References

Figures

$\Delta$

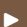

Close

\section{Full Screen / Esc}

Printer-friendly Version

Interactive Discussion 


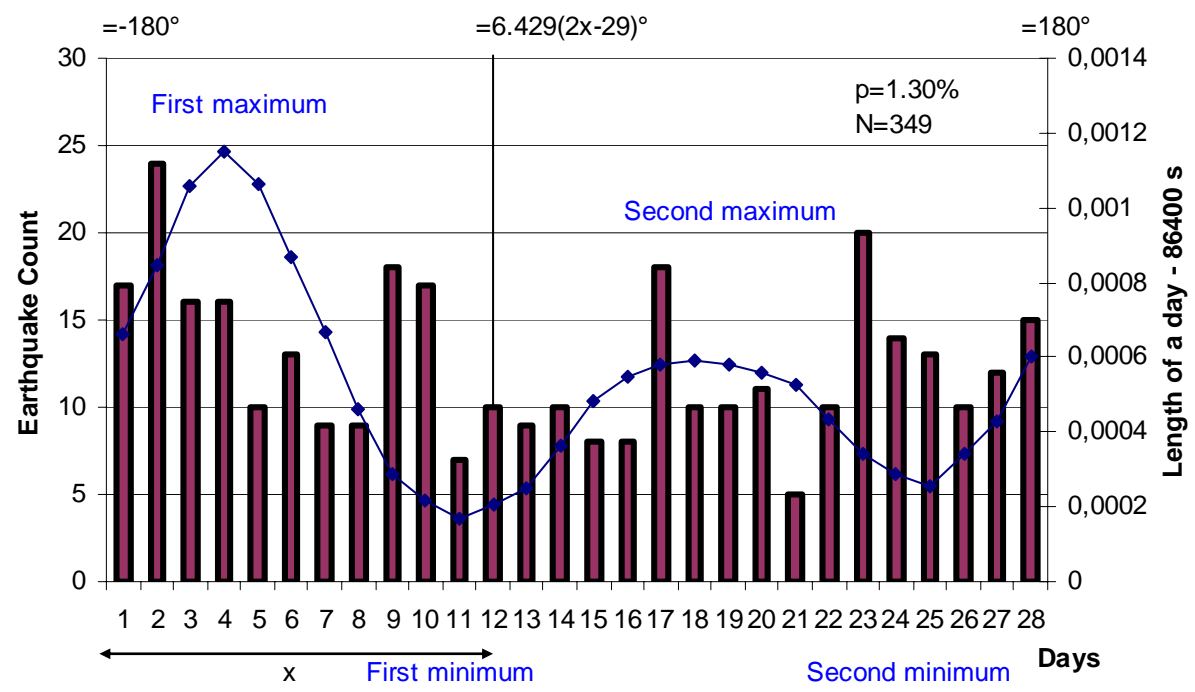

Fig. 7e. For the Chilean earthquakes the 28-interval histogram was chosen, owing to the cyclic change of bigger and smaller LOD maximum typical for LOD record in 2010 . The histogram for the Chilean subduction zone shows surprisingly good correlation, $p=1.30 \%$, for the whole 28-interval histogram. This confirms that together the LOD second minimum and 2-3 days before the first LOD maximum are the most probable earthquakes occurrences. Separating the 28 days histogram in four 8 days histograms, it shows that the first LOD maximum $p=1.39 \%$ is the most probable LOD area of earthquake triggering, Fig. 7e1-4.

\section{Earth's rotation variations and earthquakes 2010-2011}

L. Ostřihanský

\section{Title Page}

\section{Abstract}

Conclusions

\section{Tables}

14

4

Back

\section{Introduction}

References

\section{Figures}

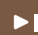

\section{Close}

\section{Full Screen / Esc}

Printer-friendly Version

Interactive Discussion 
Earthquake histogram Chile Trench

\section{3-2011 on the first LOD maximum}

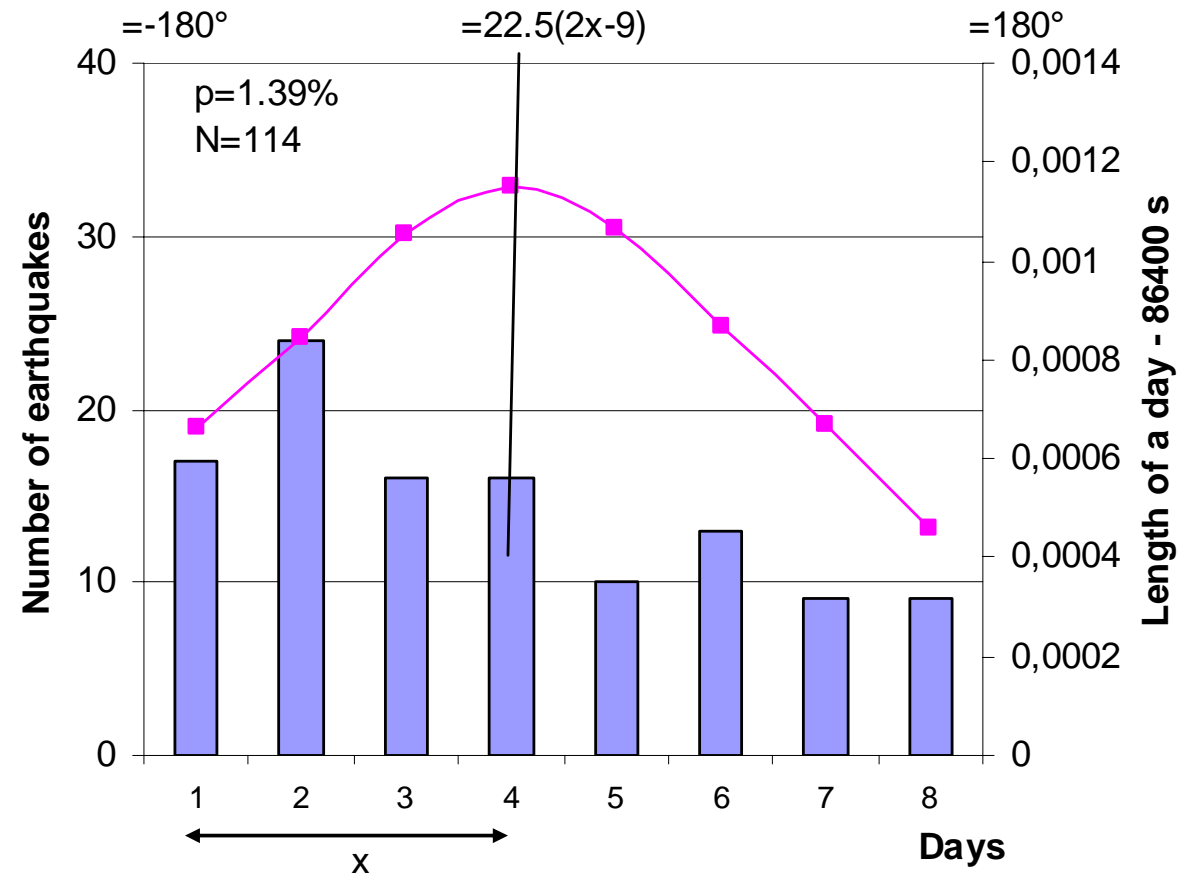

Fig. 7e1. Continued.

\section{SED}

4, 33-130, 2012

Earth's rotation variations and earthquakes 2010-2011

L. Ostřihanský

\section{Abstract}

Conclusions

Tables

14

4

Back

\section{Full Screen / Esc}

Printer-friendly Version

Interactive Discussion 
Earthquake histogram Chile Trench 1973-2011 on the first LOD minimum

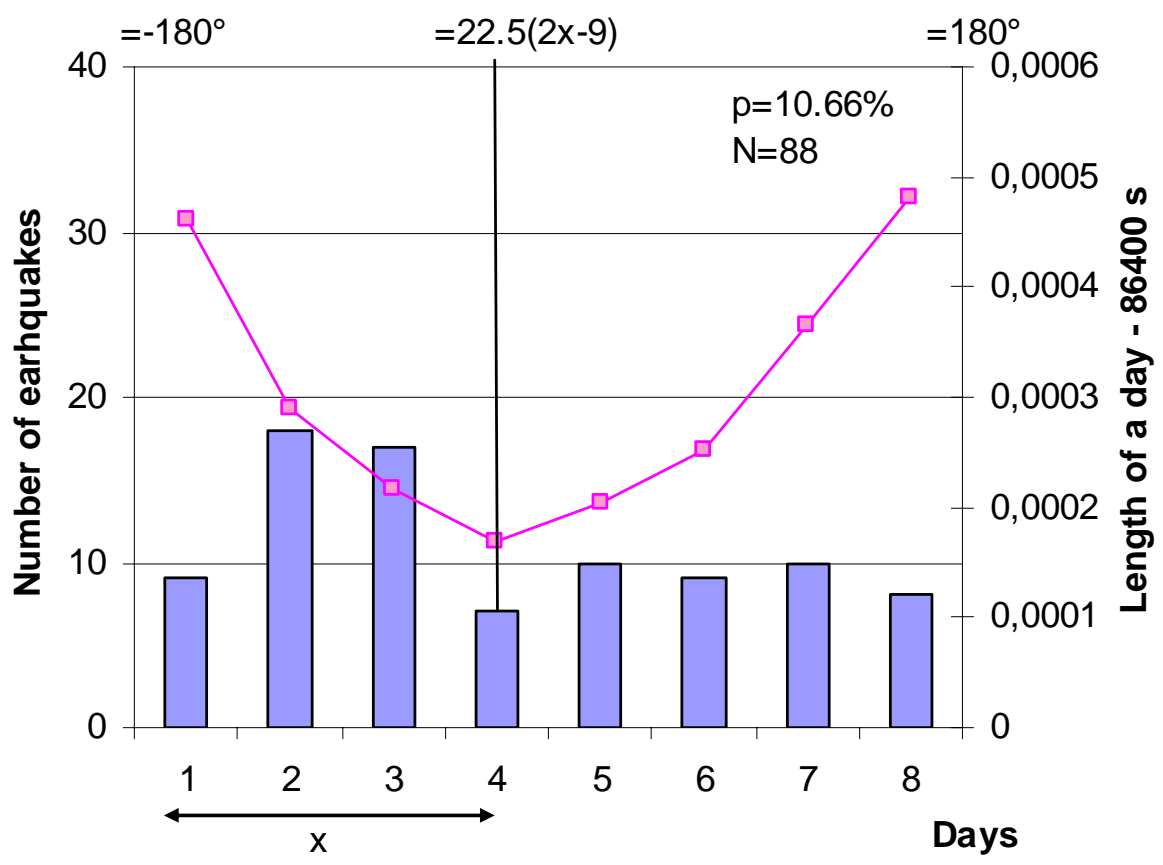

Fig. 7e2. Continued.
Earth's rotation variations and earthquakes 2010-2011

L. Ostřihanský

\section{Abstract}

Conclusions

Tables

14

4

Back

\section{Full Screen / Esc}

Printer-friendly Version

Interactive Discussion 
Earthquake histogram Chile Trench 1973-2011 on the second LOD maximum

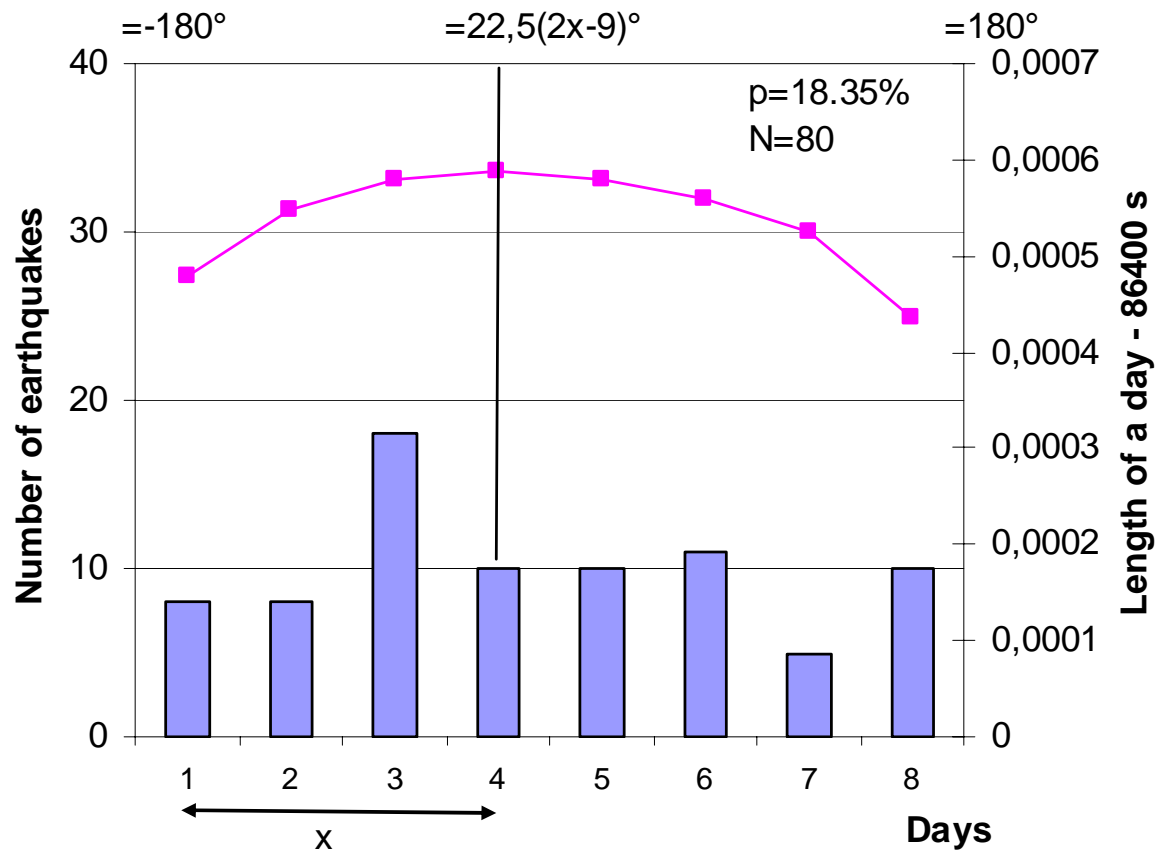

Fig. 7e3. Continued.
SED

4, 33-130, 2012

Earth's rotation variations and earthquakes 2010-2011

L. Ostřihanský

\section{Abstract}

Conclusions

Tables

14

4

Back
Full Screen / Esc

Printer-friendly Version

Interactive Discussion 


\section{Earthquake histogram Chile Trench} 1973-2011 on the second LOD minimum

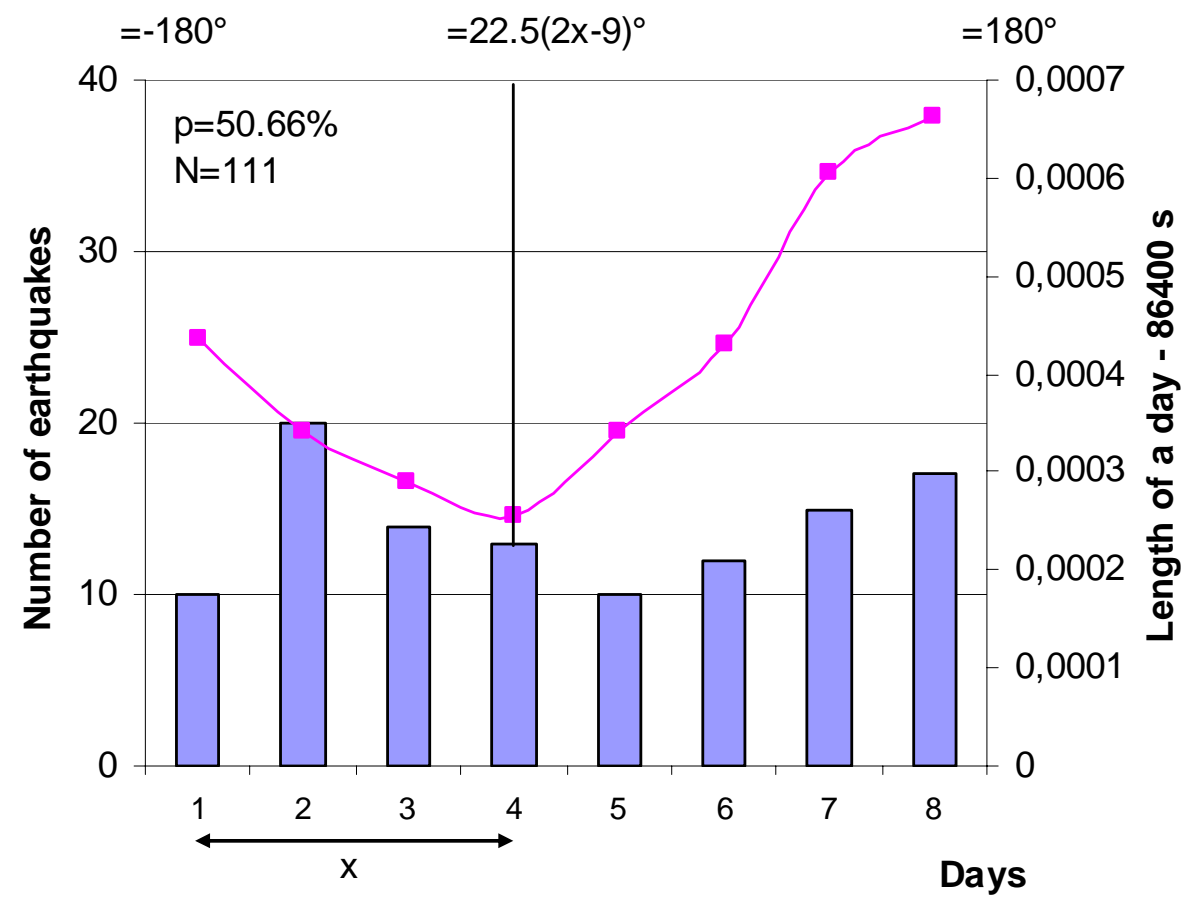

Fig. 7e4. Continued.

\section{SED}

4, 33-130, 2012

Earth's rotation variations and earthquakes 2010-2011

L. Ostřihanský

\section{Abstract}

Conclusions

Tables

14

4

Back

\section{Full Screen / Esc}

Printer-friendly Version

Interactive Discussion 


\section{Earthquake histogram Mid-Atlantic Ridge northern part} $2000-2011\left(5^{\circ} \mathrm{N}-28^{\circ} \mathrm{N}\right)$

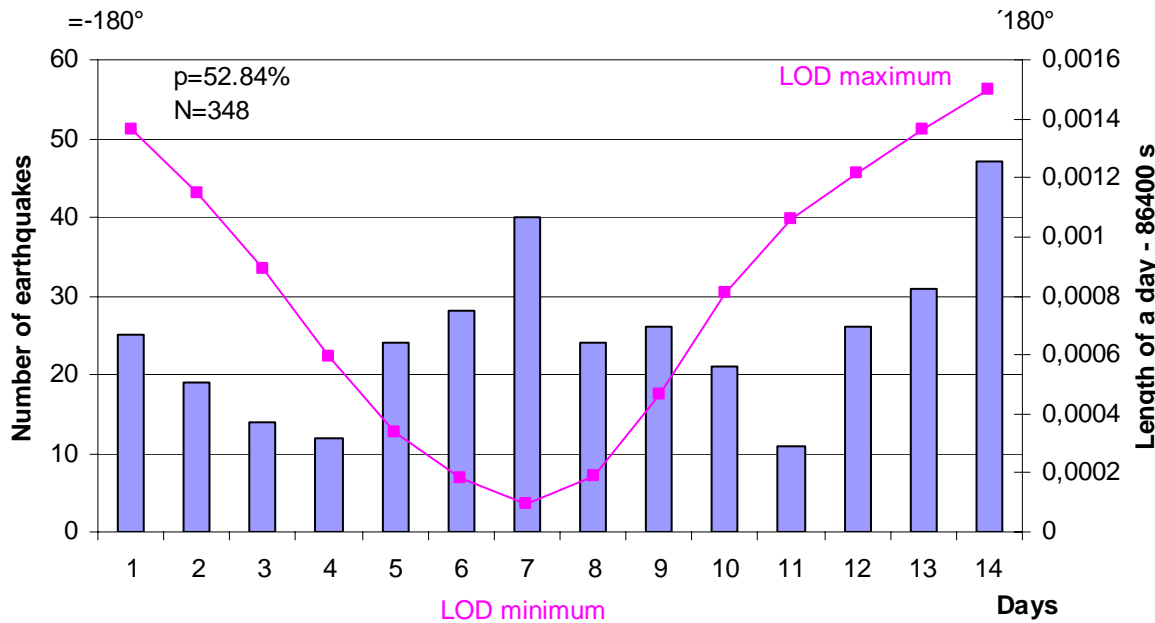

Fig. 7f. shows that earthquakes from the Mid-Atlantic Ridge are triggered both in LOD maximums and minimums, giving very high value of parameter $p=52.84 \%$. Detailed Schuster's tests for 8-interval histograms for branches or extremes confirm the clear correlation of earthquakes with LOD record, Fig. 7f1-4.

\section{Earth's rotation variations and earthquakes 2010-2011}

L. Ostřihanský

\section{Title Page}

\section{Abstract}

Introduction

Conclusions

References

Tables

Figures

14

$\rightarrow 1$

4

Back

Close

\section{Full Screen / Esc}

Printer-friendly Version

Interactive Discussion 


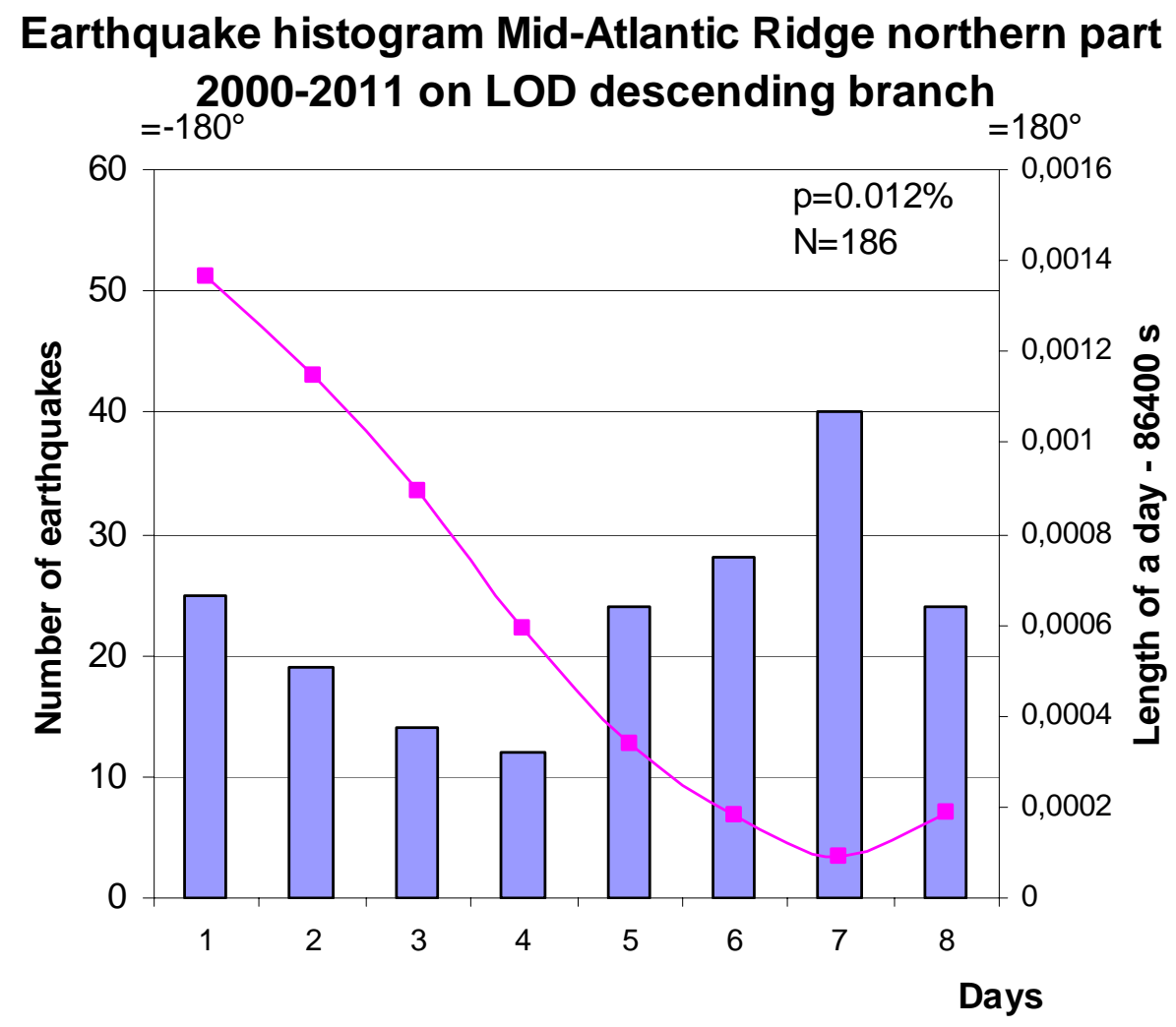

4, 33-130, 2012

Earth's rotation variations and earthquakes 2010-2011

L. Ostřihanský

Title Page

Abstract

Conclusions

Tables

14

4

Back

Full Screen / Esc

Printer-friendly Version

Interactive Discussion 
Earthquake histogram Mid-Atlantic Ridge northern part

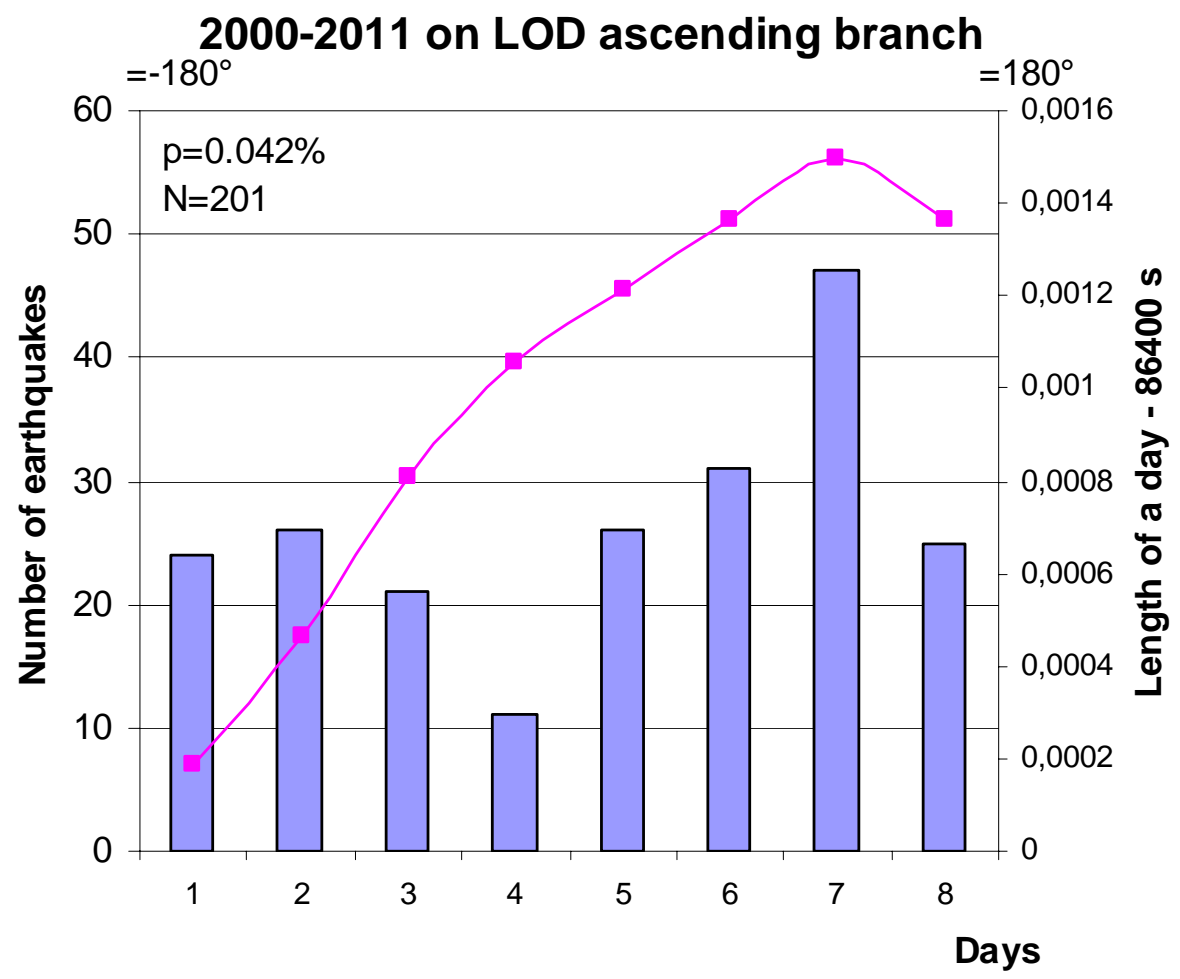

Fig. 7f2. Continued.

\section{SED}

4, 33-130, 2012

Earth's rotation variations and earthquakes 2010-2011

L. Ostřihanský

\section{Title Page}

\section{Abstract}

Conclusions

Tables

14

4

Back

Full Screen / Esc

Printer-friendly Version

Interactive Discussion 
Earthquake histogram Mid-Atlantic Ridge northern part

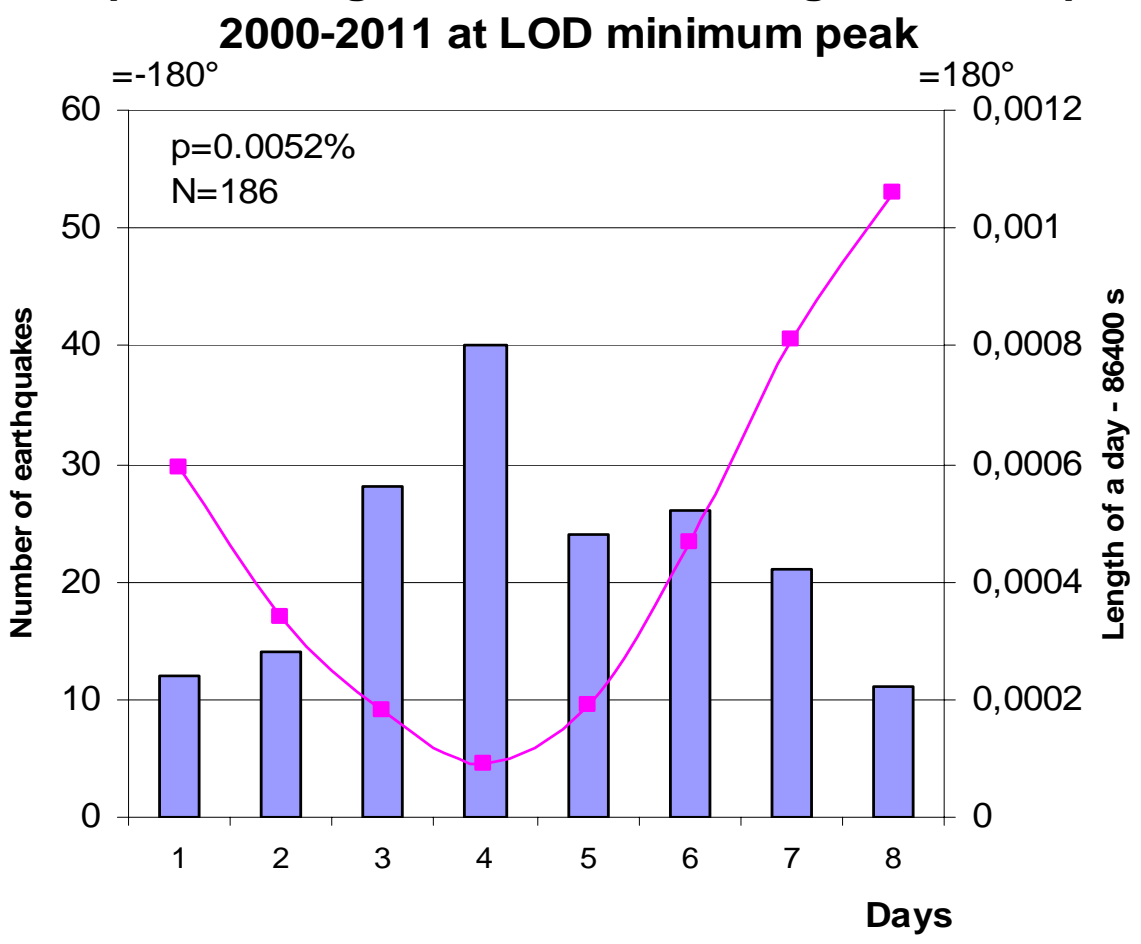

Fig. 7f3. Continued.
SED

4, 33-130, 2012

\section{Earth's rotation} variations and earthquakes 2010-2011

L. Ostřihanský

Title Page

Abstract

Introduction

Conclusions

References

Tables

Figures

14

4

Back

Close

Full Screen / Esc

Printer-friendly Version

Interactive Discussion 
Earthquake histogram Mid-Atlantic Ridge northern part

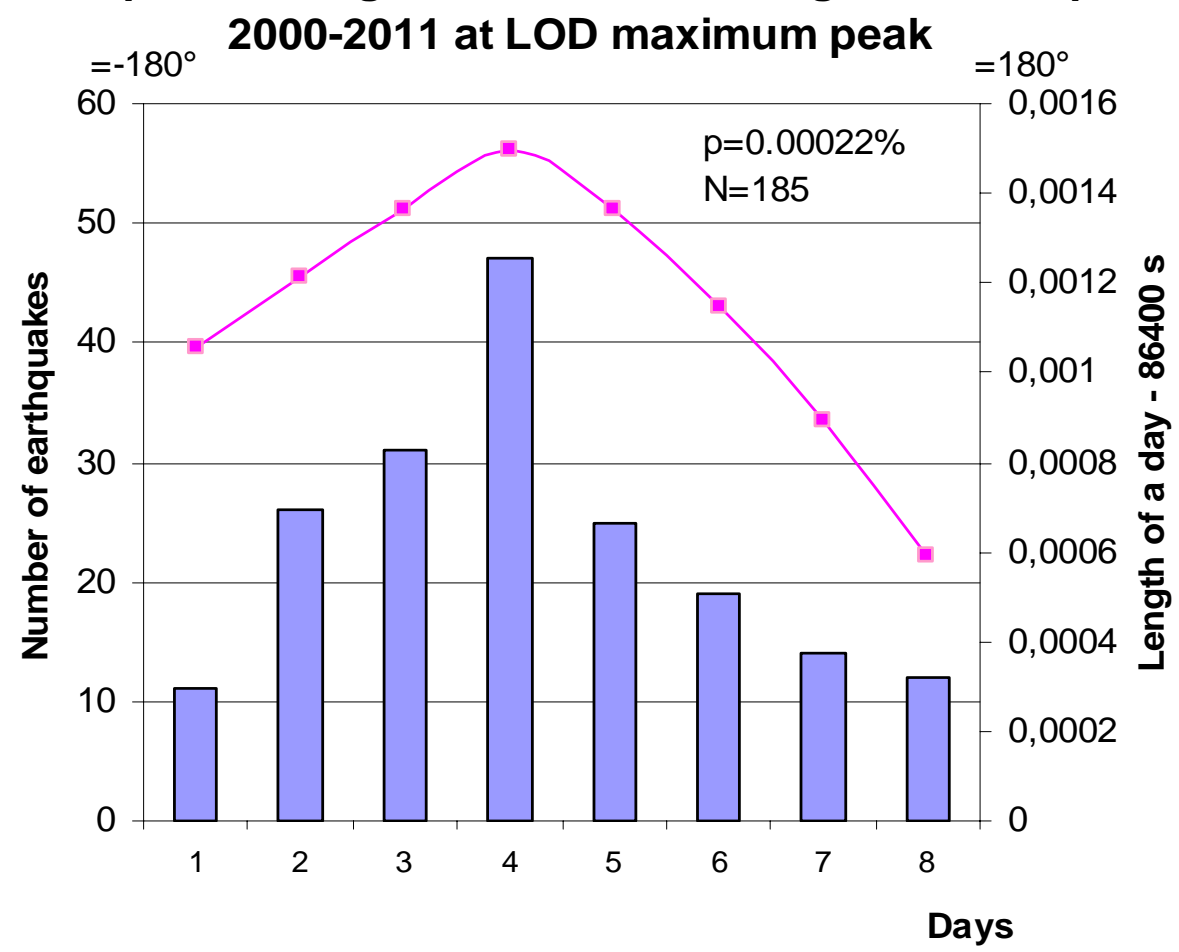

Fig. 7f4. Continued.
SED

4, 33-130, 2012

\section{Earth's rotation} variations and earthquakes 2010-2011

L. Ostřihanský

\section{Abstract}

Conclusions

Tables

14

4

Back
Title Page

Introduction

References

Figures

$\rightarrow$

$>$

Close

Full Screen / Esc

Printer-friendly Version

Interactive Discussion 
Earthquake histogram Mid-Atlantic Ridge northern part $\left(5^{\circ} \mathrm{N}-10^{\circ} \mathrm{N}\right)$ 1973-2011 and 1999-VII.2006

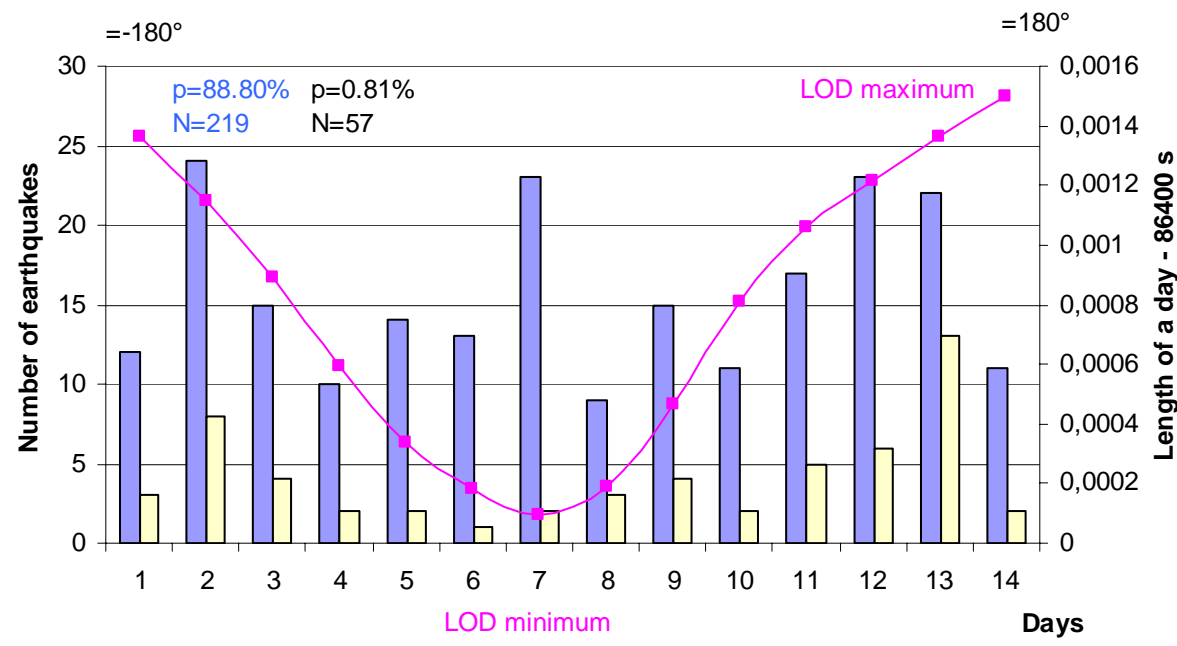

Fig. 7g. The narrow section of the Northern Mid-Atlantic Ridge shows very peculiar earthquake histogram with 3 maximums. In shorter time period there are 2 maximums close to LOD maximum, but in LOD minimum almost no earthquakes. Compare also with Fig. 8 with cyclic changes of earthquakes on both LOD branches.

\section{Earth's rotation variations and earthquakes 2010-2011}

L. Ostřihanský

\section{Title Page}

\section{Abstract}

Conclusions

\section{Tables}

14

4

Back

\section{Introduction}

References

\section{Full Screen / Esc}

Printer-friendly Version

Interactive Discussion 
Earthquake histogram Mid-Atlantic Ridge northern part $\left(5^{\circ} \mathrm{N}-10^{\circ} \mathrm{N}\right) 1973-2011$ on descending LOD branch

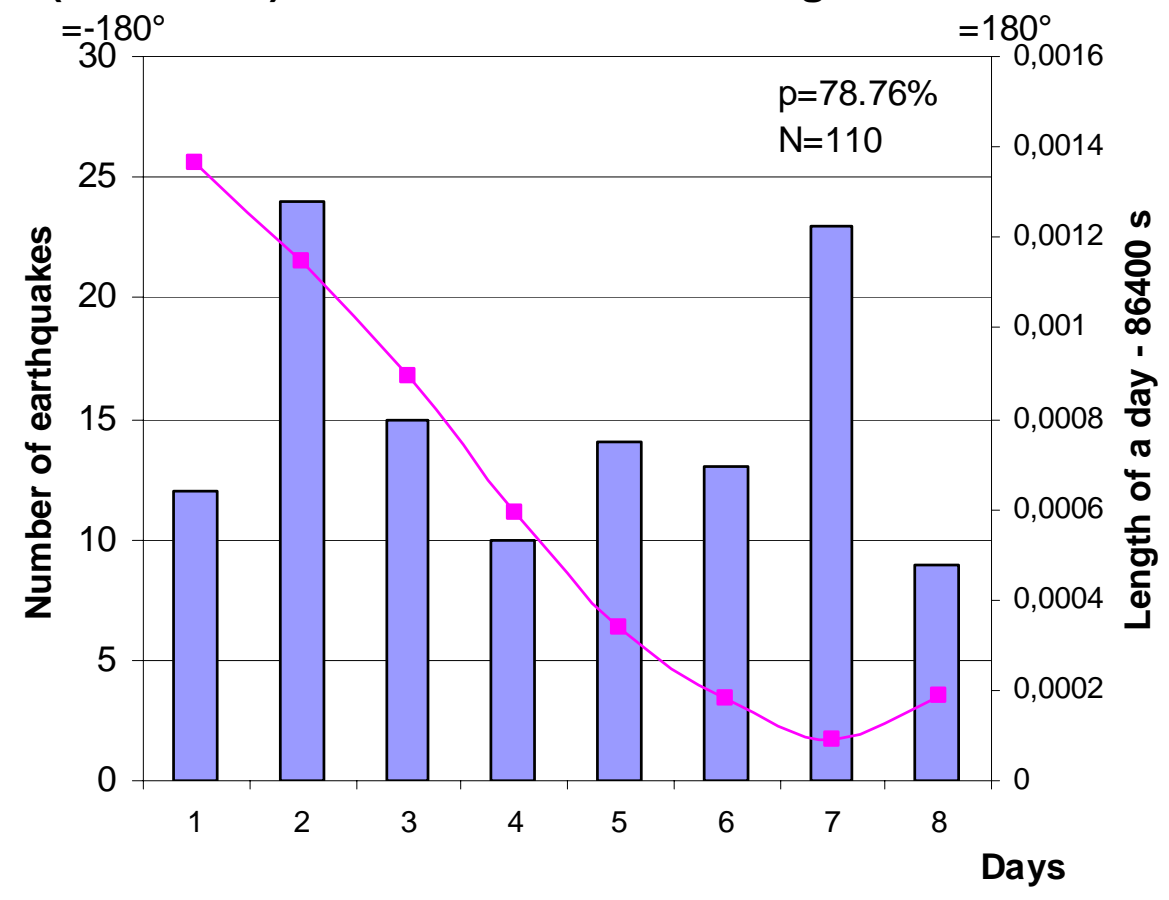

Fig. 7g1. Continued.
SED

4, 33-130, 2012

Earth's rotation variations and earthquakes 2010-2011

L. Ostřihanský

\section{Abstract}

Conclusions

Tables

14

4

Back

\section{Full Screen / Esc}

Printer-friendly Version

Interactive Discussion 
Earthquake histogram Mid-Atlantic Ridge northern part $\left(5^{\circ} \mathrm{N}-10^{\circ} \mathrm{N}\right) 1973-2011$ on ascending LOD branch

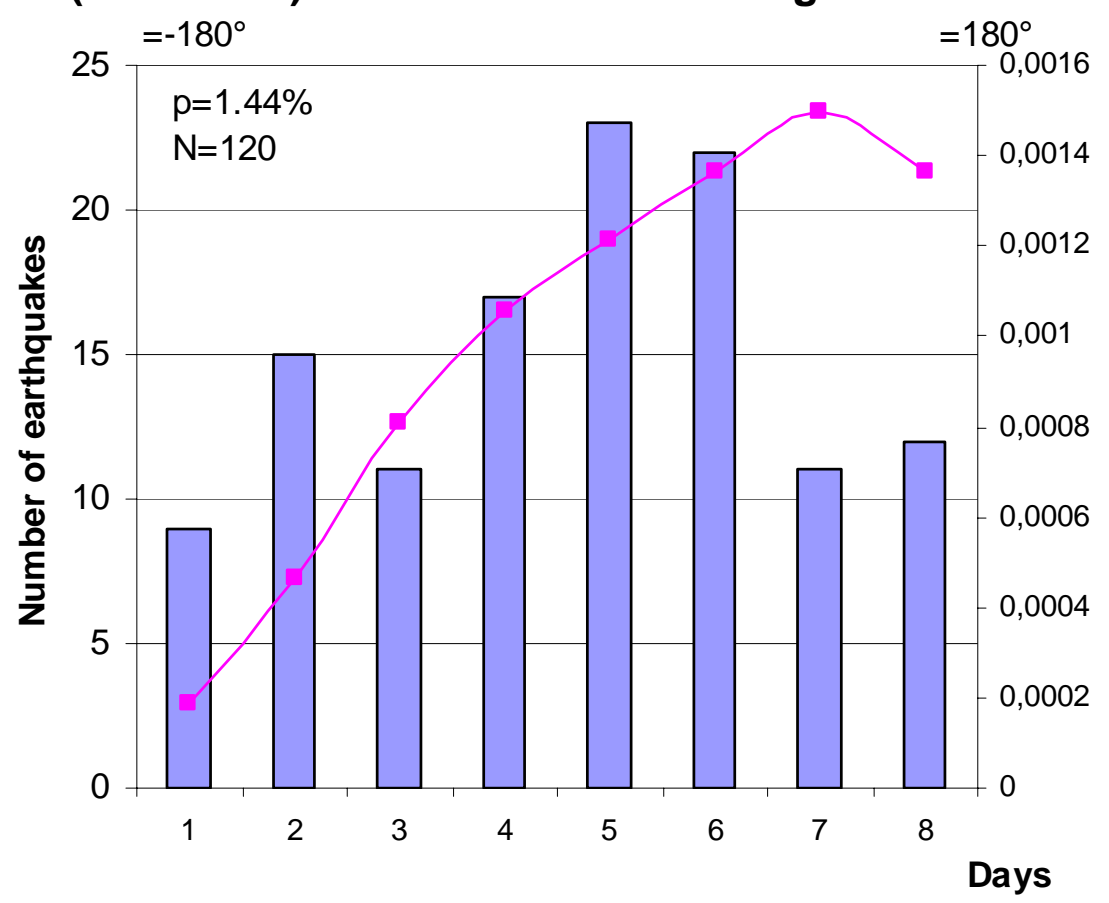

Fig. 7g2. Continued.

\section{SED}

4, 33-130, 2012

Earth's rotation variations and earthquakes 2010-2011

L. Ostřihanský

\section{Title Page}

\section{Abstract}

Conclusions

Tables

14

Back
Full Screen / Esc

Printer-friendly Version

Interactive Discussion 
Earthquake histogram Mid-Atlantic Ridge northern part parallel with meridian $1976-2011\left(15^{\circ} \mathrm{N}-23.5^{\circ} \mathrm{N}\right)$

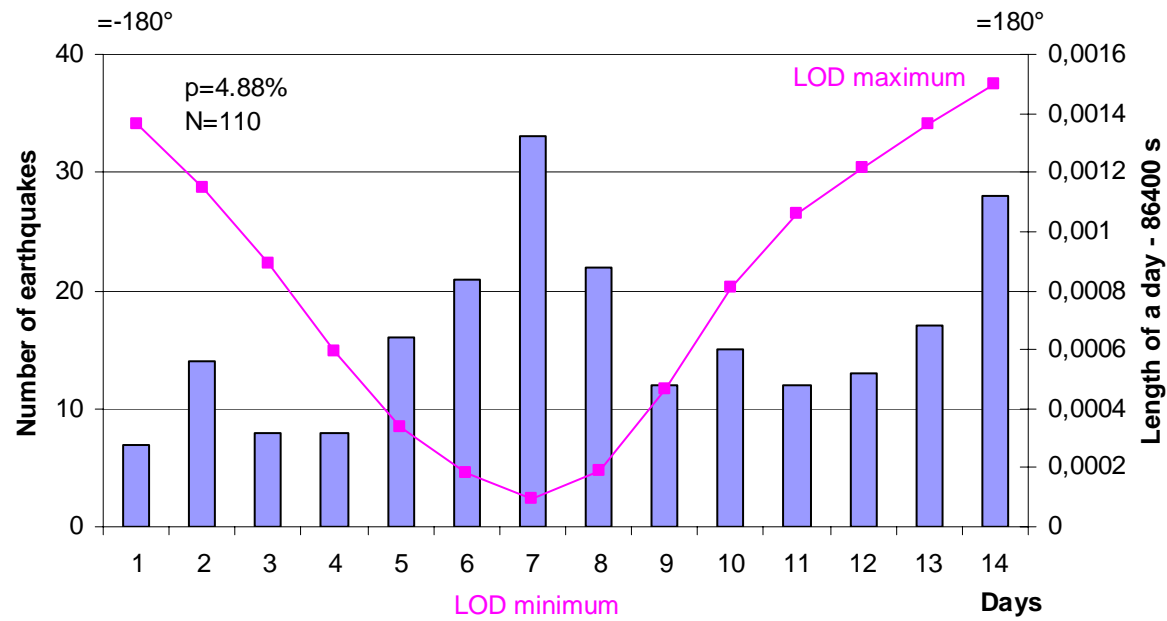

Fig. 7h. shows histogram of the northern part of the Mid-Atlantic Ridge but in narrow section $44-48^{\circ} \mathrm{W}$ where the Mid Atlantic Ridge is parallel with longitude (Fig. $\left.7 \mathrm{~h} 1-4\right)$ to avoid maximally the effect of transform faults intersecting perpendicularly the Mid-Atlantic Ridge. Earthquakes on ascending LOD branch are more numerous (Table 2 ) and not correlating with LOD maximum (Fig. 7h2). There are earthquakes in Mid-Atlantic Ridge preceding earthquakes in transform faults, including the Haiti earthquake of 12 January 2010. See Fig. 4c.

\section{Earth's rotation variations and earthquakes 2010-2011}

L. Ostřihanský

\section{Abstract}

Conclusions

\section{Tables}

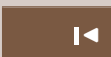

\section{4}

\section{Back}

\section{Full Screen / Esc}

Printer-friendly Version

Interactive Discussion 
Earthquake histogram Mid-Atlantic Ridge northern part parallel with meridian $1976-2011\left(15^{\circ} \mathrm{N}-23.5^{\circ} \mathrm{N}\right)$ along

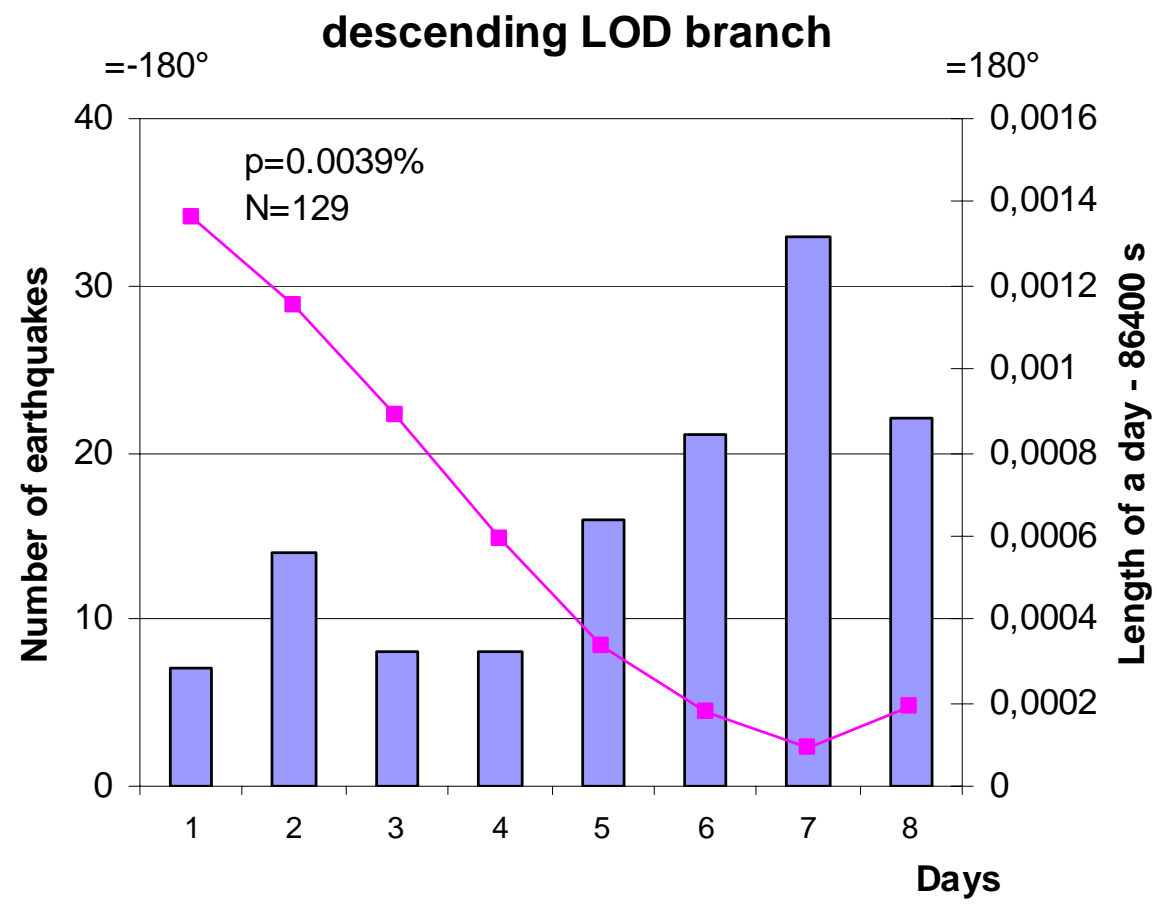

SED

4, 33-130, 2012

Earth's rotation variations and earthquakes 2010-2011

L. Ostřihanský

\section{Abstract}

Conclusions

Tables

14

4

Back

Fig. 7h1. Continued.

\section{Full Screen / Esc}

Printer-friendly Version

Interactive Discussion 
Earthquake histogram Mid-Atlantic Ridge northern part parallel with meridian $1976-2011\left(15^{\circ} \mathrm{N}-23.5^{\circ} \mathrm{N}\right)$ along ascending LOD branch

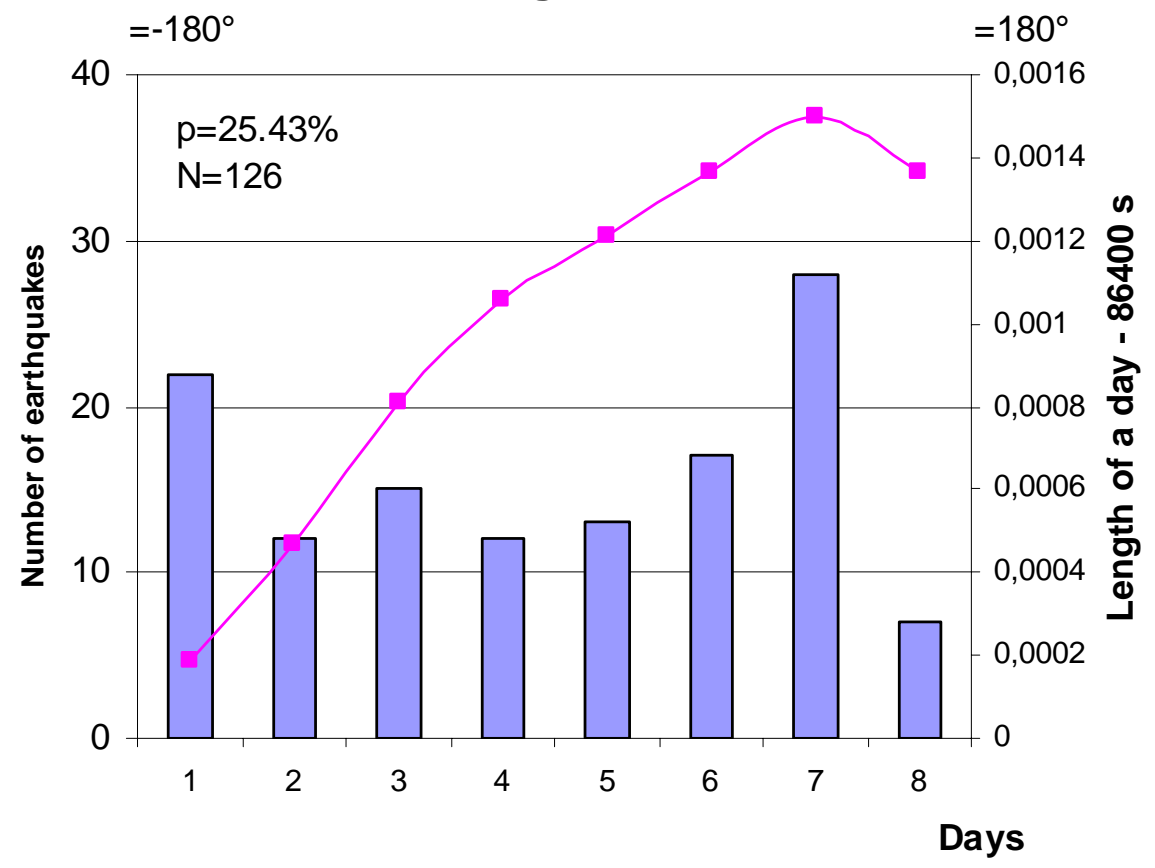

Fig. 7h2. Continued.
SED

4, 33-130, 2012

Earth's rotation variations and earthquakes 2010-2011

L. Ostřihanský

Title Page

Abstract

Introduction

Conclusions

References

Tables

Figures

14

4

Back

Full Screen / Esc

Printer-friendly Version

Interactive Discussion 
Earthquake histogram Mid-Atlantic Ridge northern part parallel with meridian $1976-2011\left(15^{\circ} \mathrm{N}-23.5^{\circ} \mathrm{N}\right)$ at LOD

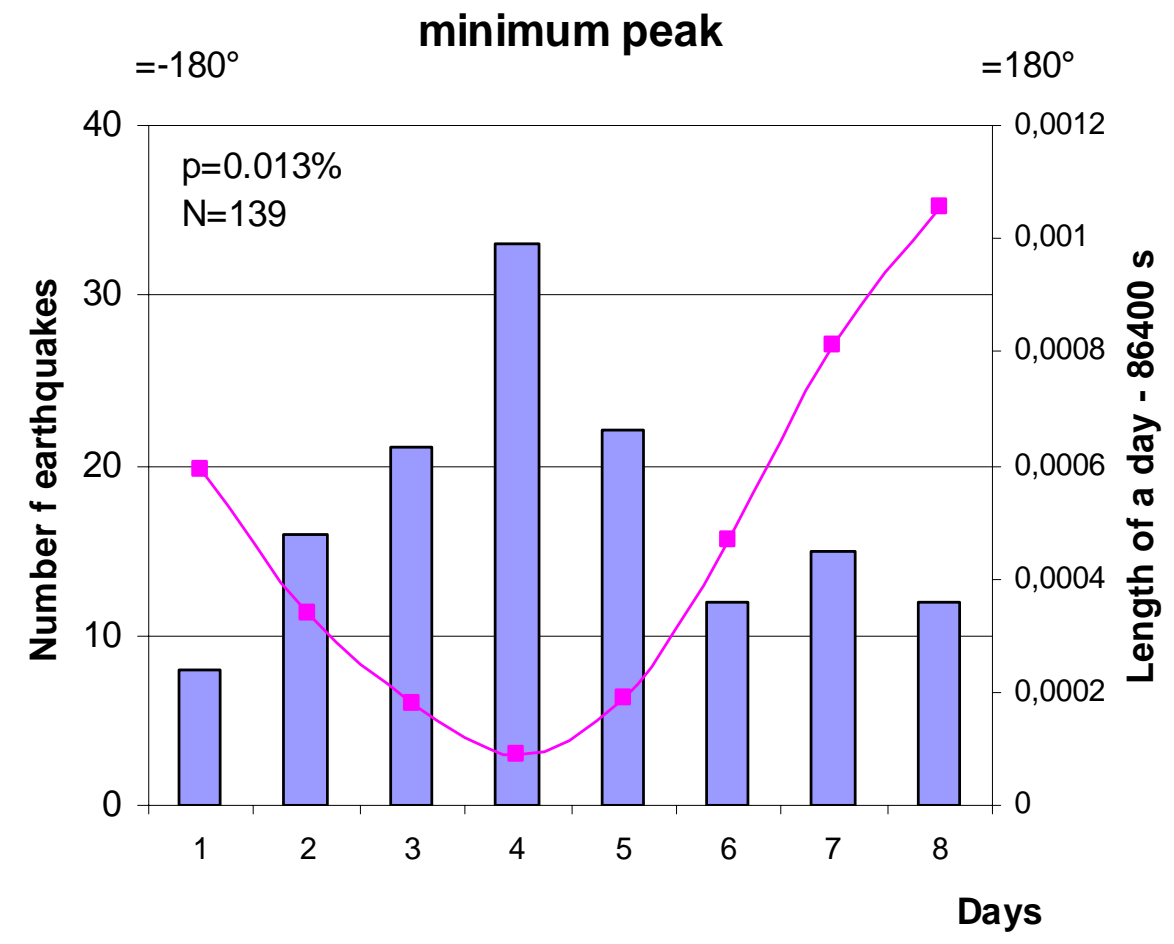

SED

4, 33-130, 2012

Earth's rotation variations and earthquakes 2010-2011

L. Ostřihanský

\section{Abstract}

Conclusions

Tables

14

4

Back

Fig. 7h3. Continued.

Printer-friendly Version

Interactive Discussion 
Earthquake histogram Mid-Atlantic Ridge northern part parallel with meridian $1976-2011\left(15^{\circ} \mathrm{N}-23.5^{\circ} \mathrm{N}\right)$ at LOD

$$
=-180^{\circ}
$$
maximum peak

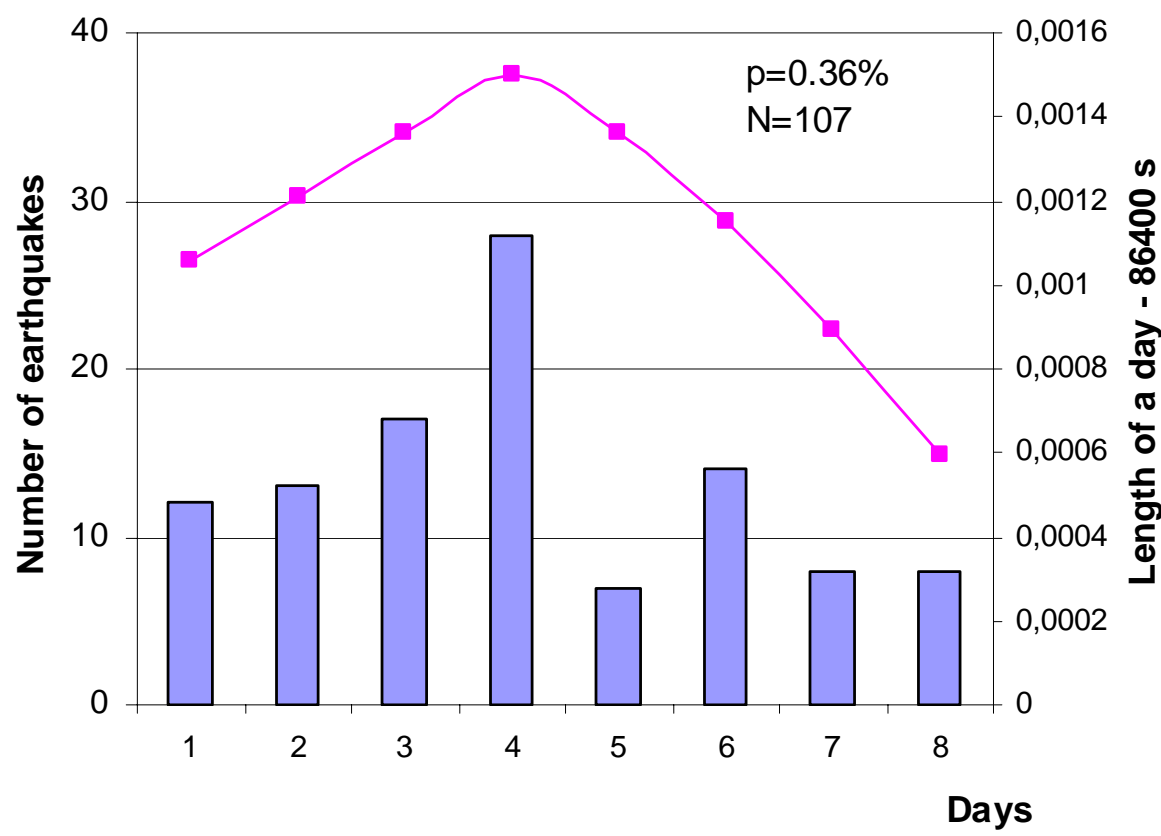

Fig. 7h4. Continued.
SED

4, 33-130, 2012

Earth's rotation variations and earthquakes 2010-2011

L. Ostřihanský

Title Page
Abstract

Conclusions

Tables

14

4

Back
Introduction

References

Figures

$\Delta$

Close

\section{Full Screen / Esc}

Printer-friendly Version

Interactive Discussion 
Earthquake histogram Mid-Atlantic Ridge central part parallel with equator 2000-2011

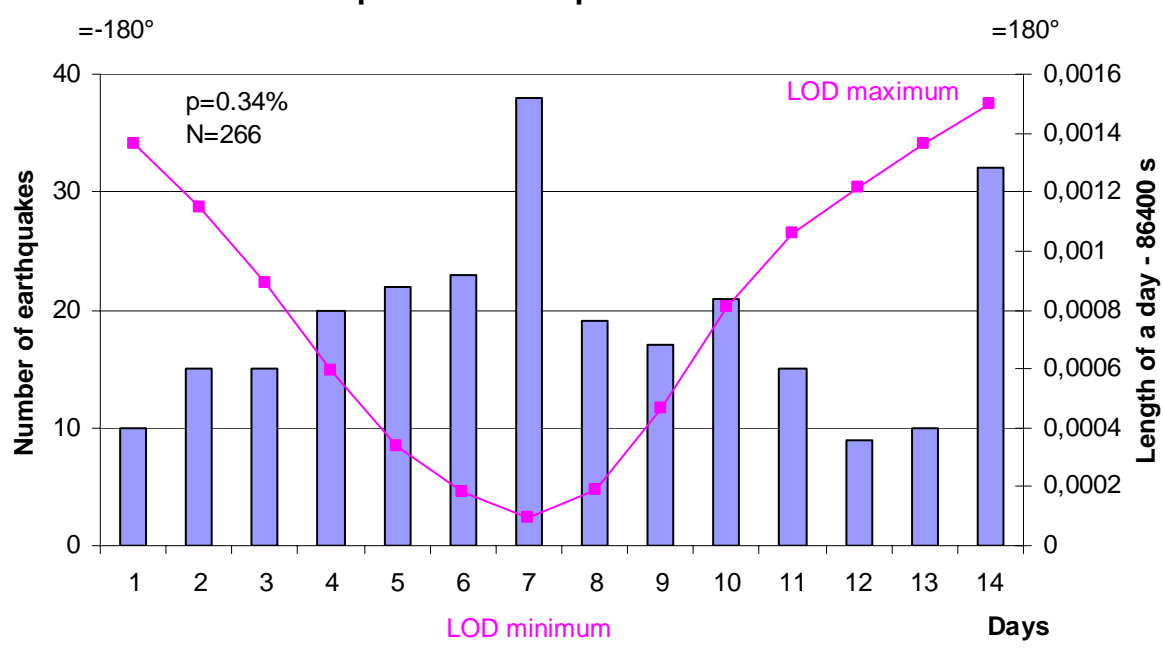

Fig. 7i. In contrast to Fig. $7 \mathrm{~h}$, there are more numerous earthquakes in the accelerating LOD branch because the section chosen is in narrow band $\left(0-2.5^{\circ} \mathrm{N}\right)$ parallel with equator; it reflects the westward movement.

\section{Earth's rotation variations and earthquakes 2010-2011}

L. Ostřihanský

\section{Abstract}

Conclusions

\section{Tables}

14

4

Back
Introduction

References

\section{Full Screen / Esc}

Printer-friendly Version

Interactive Discussion 
Earthquake histogram Mid-Atlantic Ridge central part parallel with equator 2000-2011 on LOD descending branch

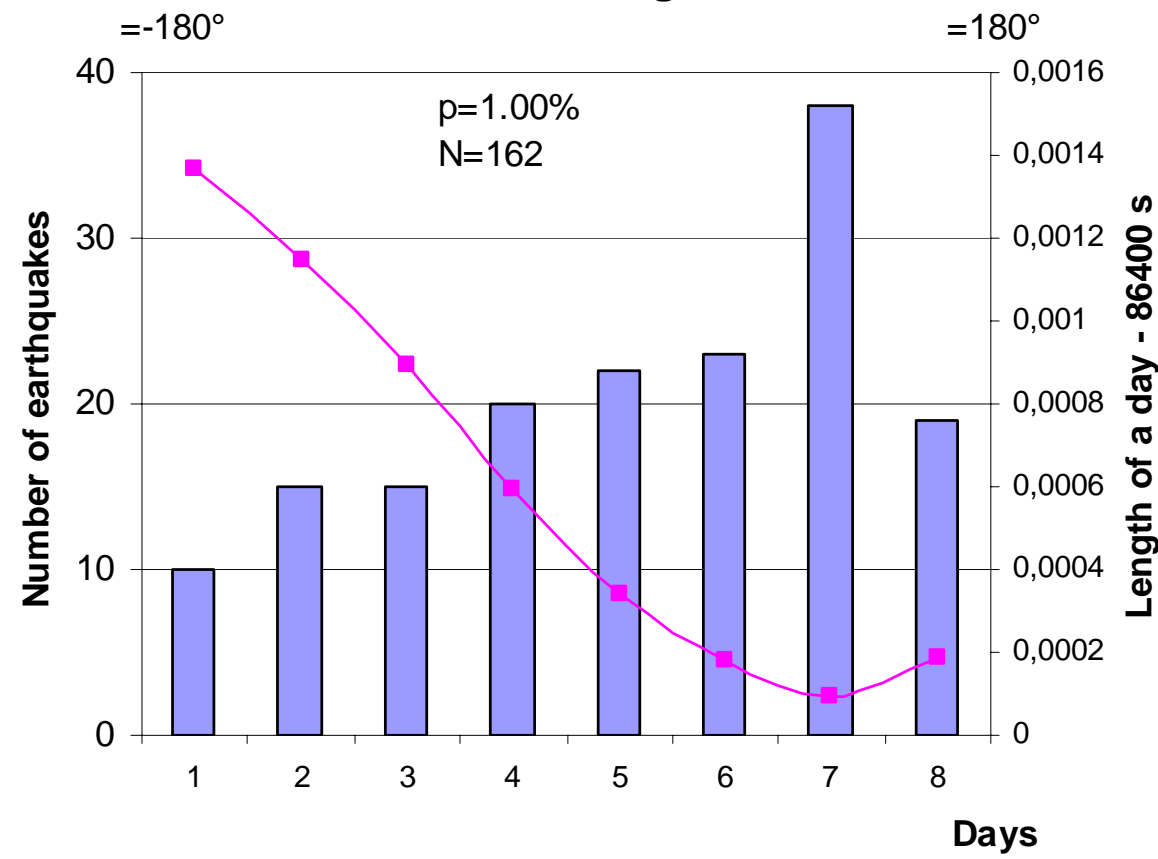

Fig. 7i1. Continued.

SED

4, 33-130, 2012

\section{Earth's rotation} variations and earthquakes 2010-2011

L. Ostřihanský

Title Page

Abstract

Conclusions

Tables

14

4

Back

Full Screen / Esc

Printer-friendly Version

Interactive Discussion 
Earthquake histogram Mid-Atlantic Ridge central part parallel with equator 2000-2011 on LOD ascending branch

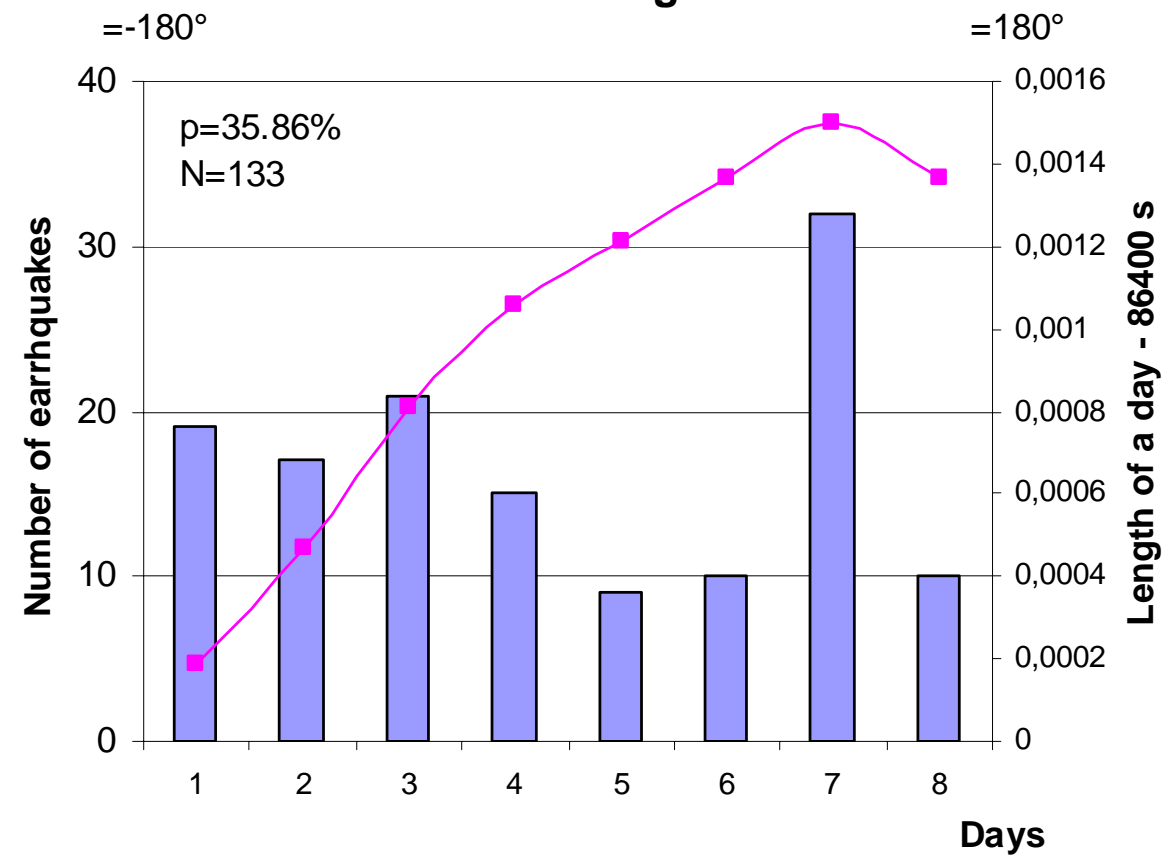

Fig. 7i2. Continued.
SED

4, 33-130, 2012

\section{Earth's rotation} variations and earthquakes 2010-2011

L. Ostřihanský

Title Page

Abstract

Introduction

Conclusions

References

Tables

Figures

14

4

Back

Full Screen / Esc

Printer-friendly Version

Interactive Discussion 


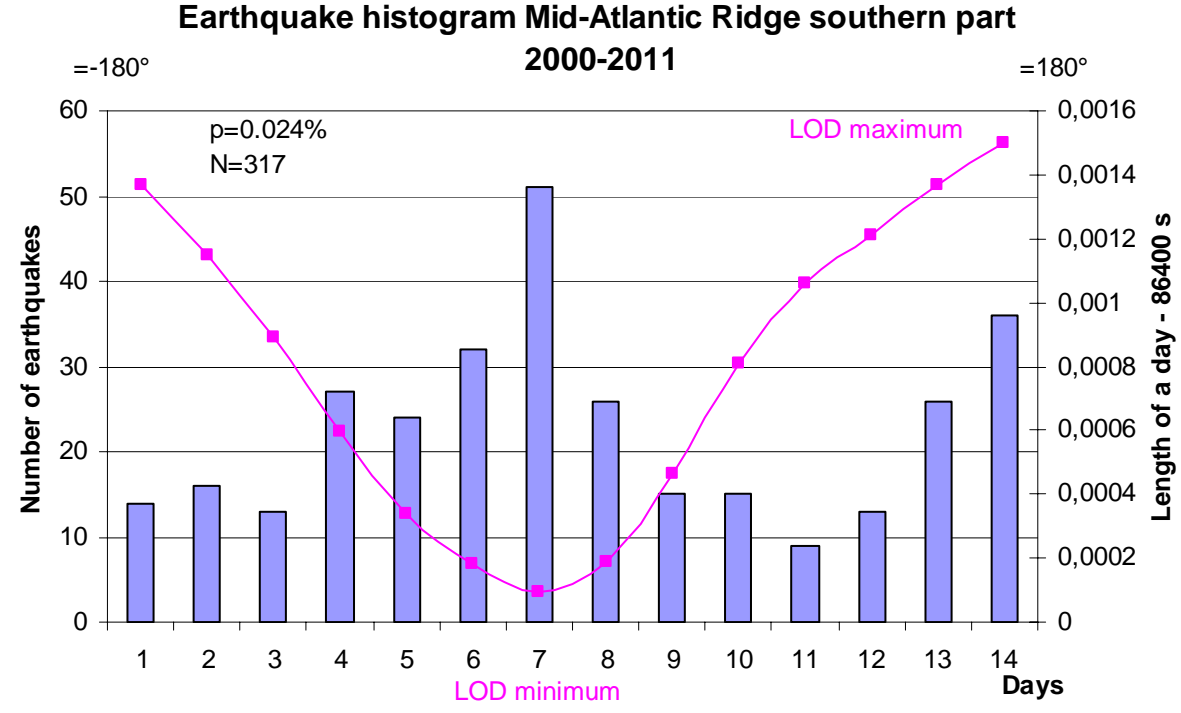

Fig. 7j. Histogram from the southern part of the Mid Atlantic Ridge shows even more earthquakes in descending LOD branch than in Fig. 7i. This confirms quick westward movement in the Earth's acceleration.

\section{Earth's rotation variations and earthquakes 2010-2011}

L. Ostřihanský

\section{Abstract}

Conclusions

\section{Tables} 1

14

4

Back
Title Page

\section{Introduction}

References

Figures

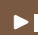

$\triangleright$

Close

\section{Full Screen / Esc}

Printer-friendly Version

Interactive Discussion 
Earthquake histogram Mid-Atlantic Ridge southern part 2000-2011 on LOD descending branch

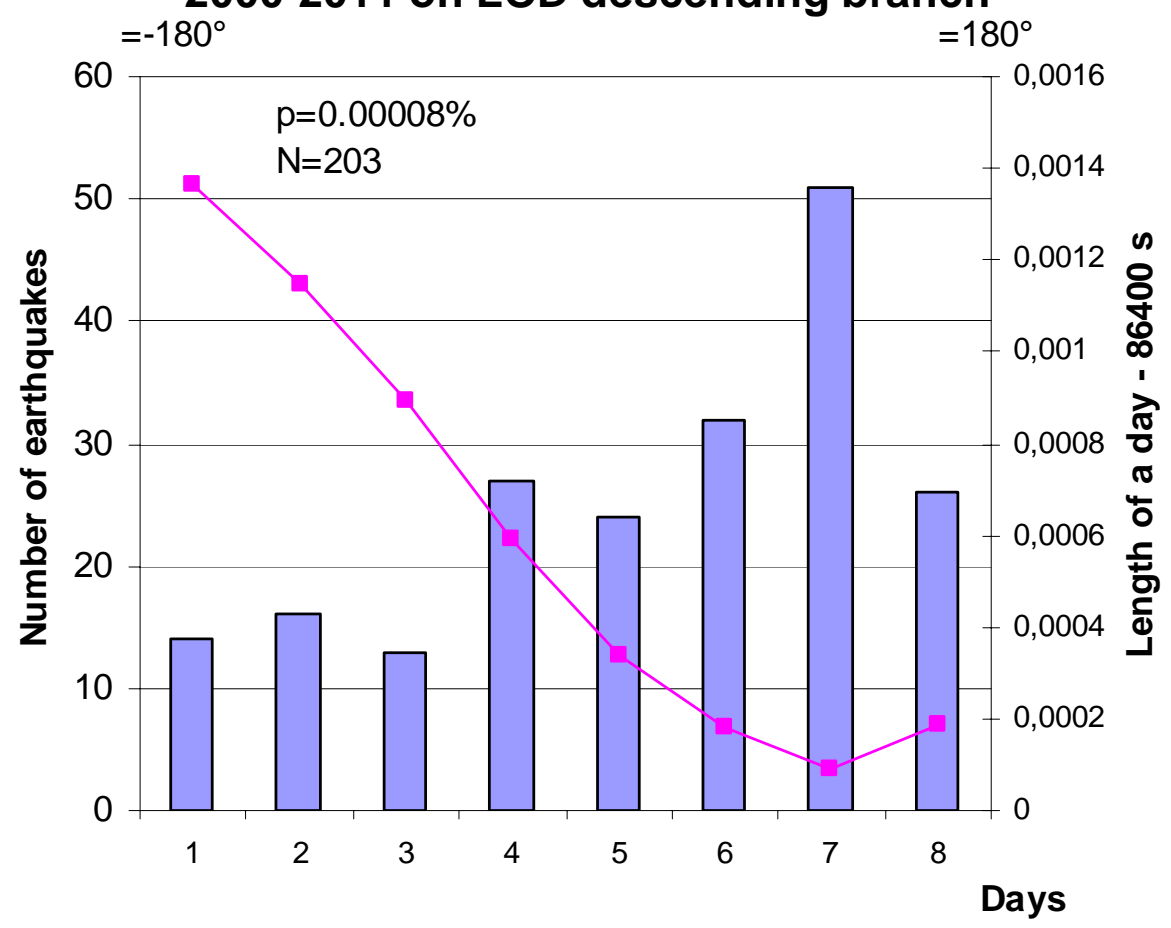

Fig. 7j1. Continued.

SED

4, 33-130, 2012

Earth's rotation variations and earthquakes 2010-2011

L. Ostřihanský

Title Page

Abstract

Conclusions

Tables

14

4

Back

Full Screen / Esc

Printer-friendly Version

Interactive Discussion 
Earthquake histogram Mid-Atlantic Ridge southern part 2000-2011 on LOD ascending branch

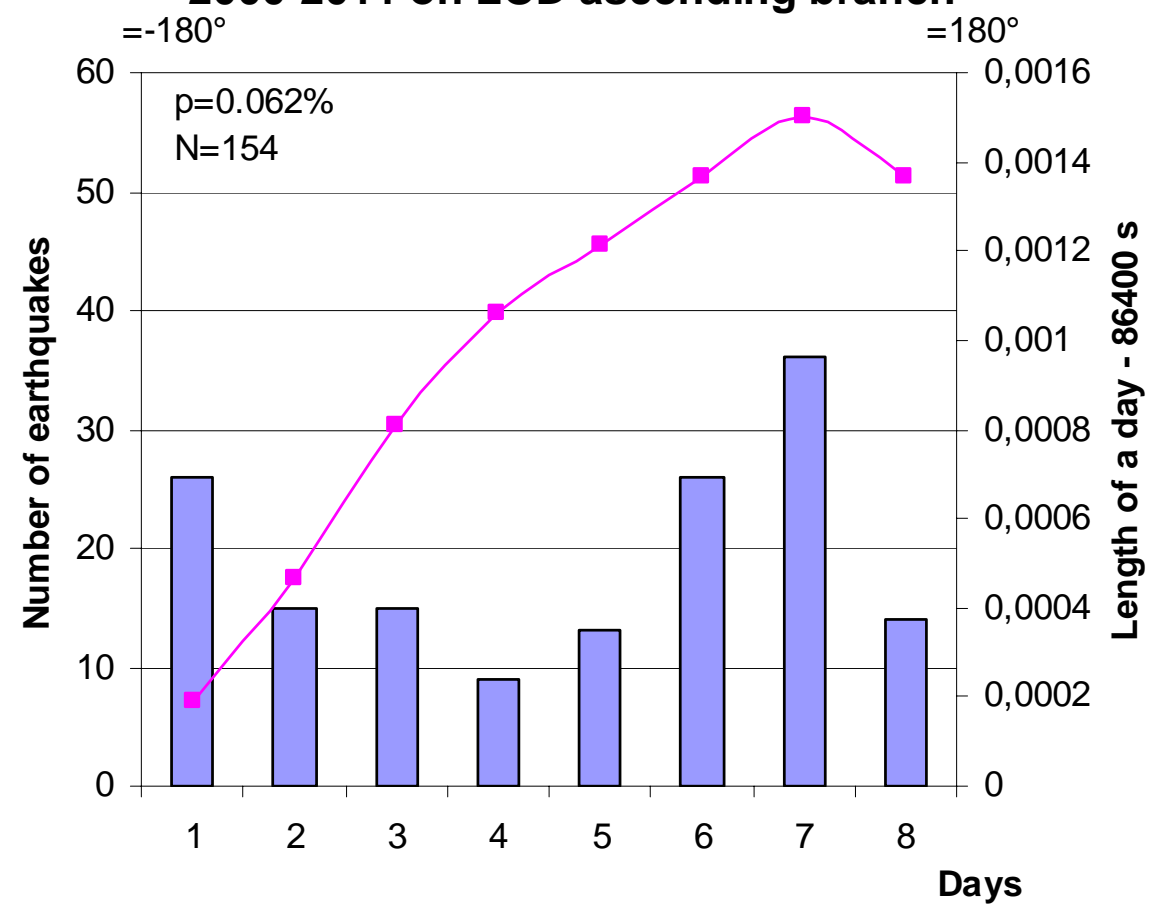

Fig. 7j2. Continued.

SED

4, 33-130, 2012

Earth's rotation variations and earthquakes 2010-2011

L. Ostřihanský

Title Page

Abstract

Conclusions

Tables

14

4

Back

Full Screen / Esc

Printer-friendly Version

Interactive Discussion 


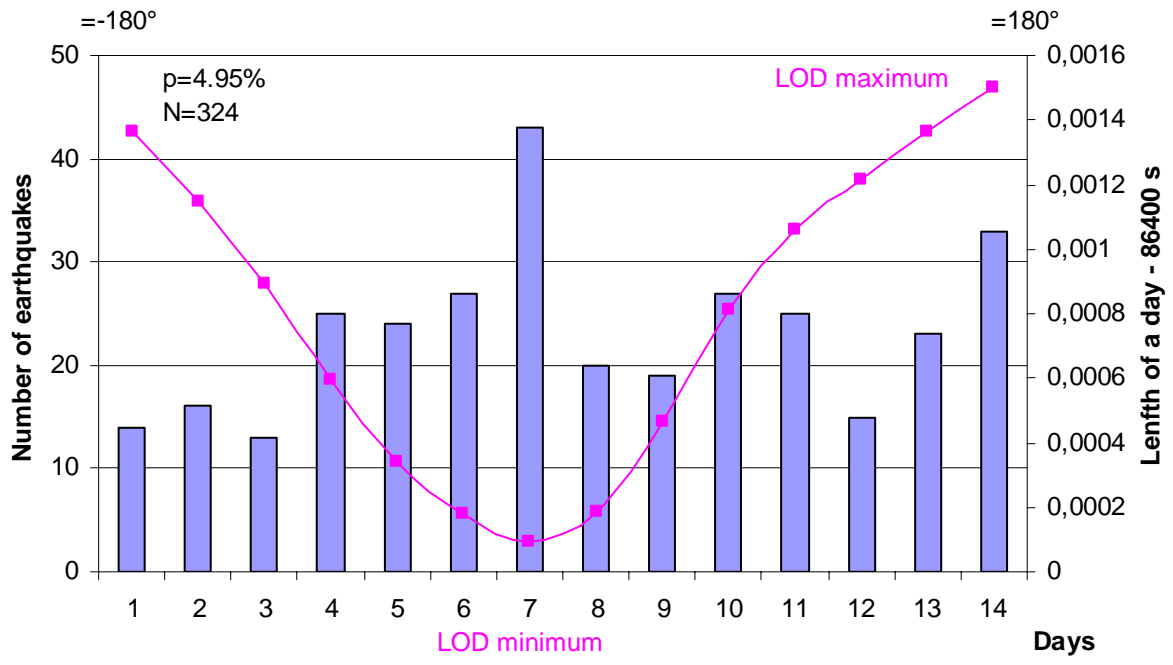

Fig. 7k. The 14-interval histogram shows $p=4.95 \%$ that for the whole 13.66 days period, the earthquake occurrence in the LOD minimum is the most probable. Better results the 8-interval shows, Fig. $7 \mathrm{k} 1 p=0.13 \%$. However, the 8-interval histogram Fig. $7 \mathrm{k} 3$ in center of LOD minimum in spite of partly apparent correlation of LOD minimum and earthquake maximum, owing to evident non-random distribution the parameter $p=22.45 \%$ is high. Similar case shown in Fig. $7 \mathrm{k} 4$.

\section{Earth's rotation variations and earthquakes 2010-2011}

L. Ostřihanský

\section{Title Page}

\section{Abstract}

Introduction

Conclusions

References

Tables

Figures

14

$\Delta$

Back

Close

\section{Full Screen / Esc}

Printer-friendly Version

Interactive Discussion 


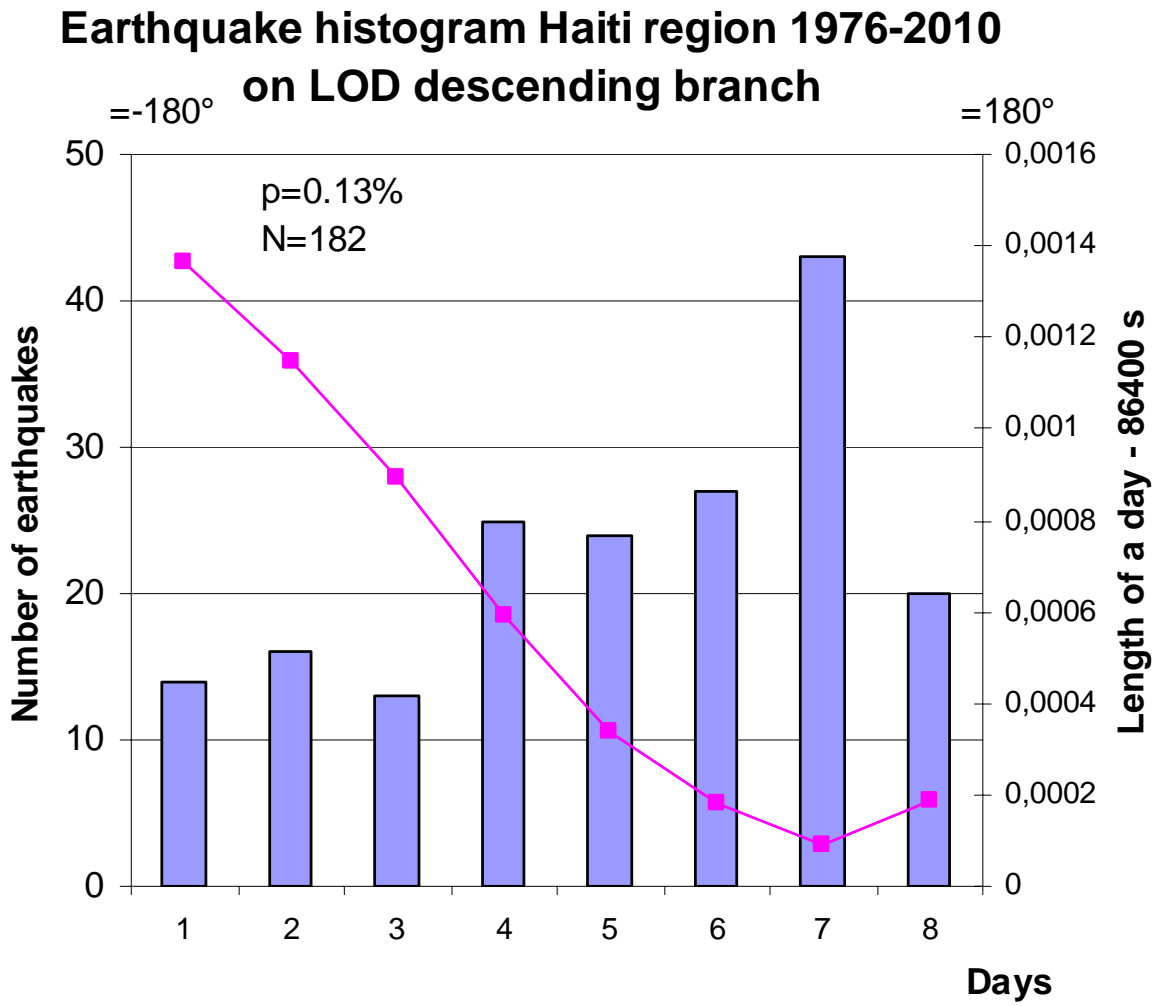

4, 33-130, 2012

Earth's rotation variations and earthquakes 2010-2011

L. Ostřihanský

Title Page

Abstract

Conclusions

Tables

14

4

Back

Full Screen / Esc

Printer-friendly Version

Interactive Discussion 


\section{Earthquake histogram Haiti region 1976-2010}

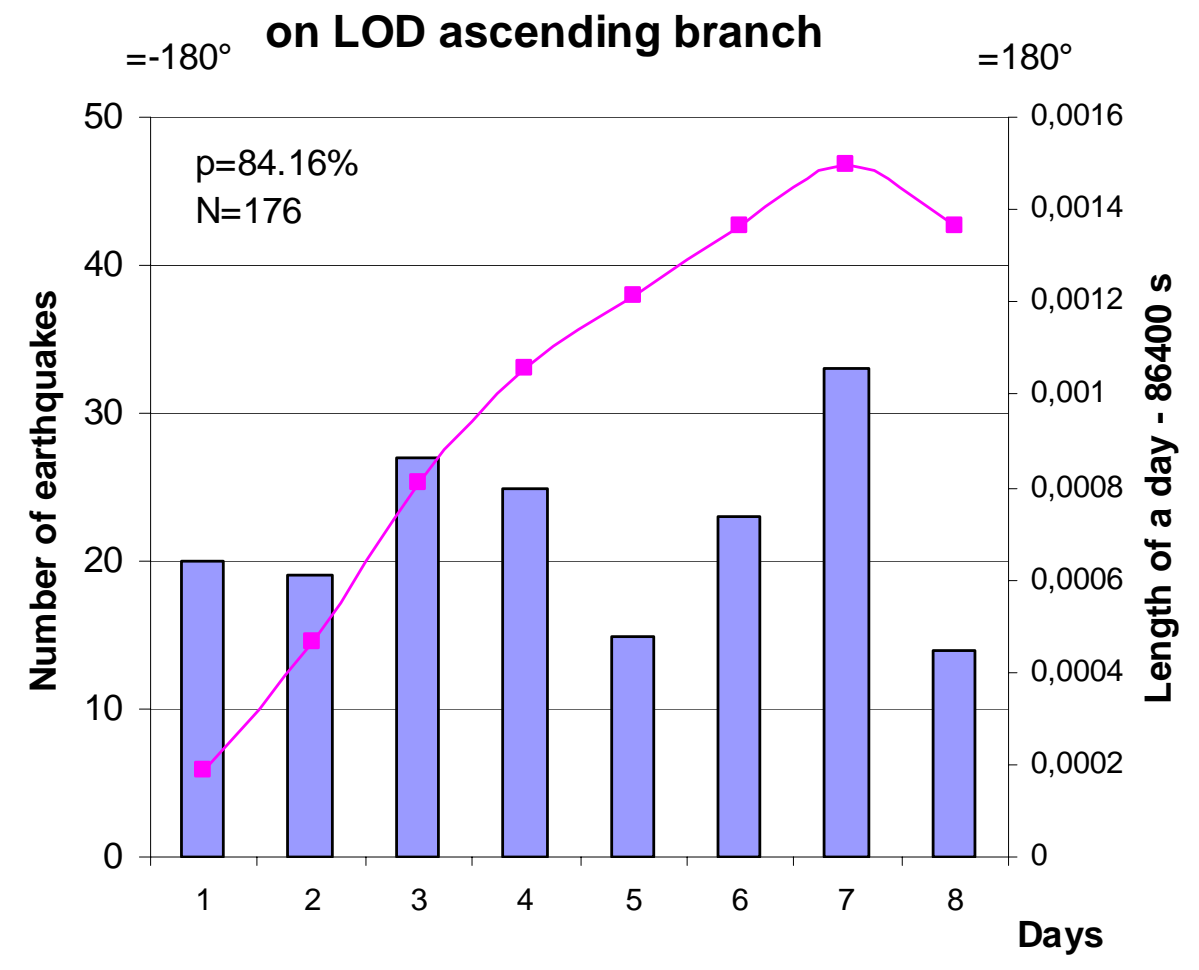

Fig. 7k2. Continued.
SED

4, 33-130, 2012

\section{Earth's rotation} variations and earthquakes 2010-2011

L. Ostřihanský

Title Page

Abstract

Introduction

Conclusions References

Tables

Figures

14

4

Back

Full Screen / Esc

Printer-friendly Version

Interactive Discussion 
Earthquake histogram Haiti region 1976-2010 at LOD mnimum peak

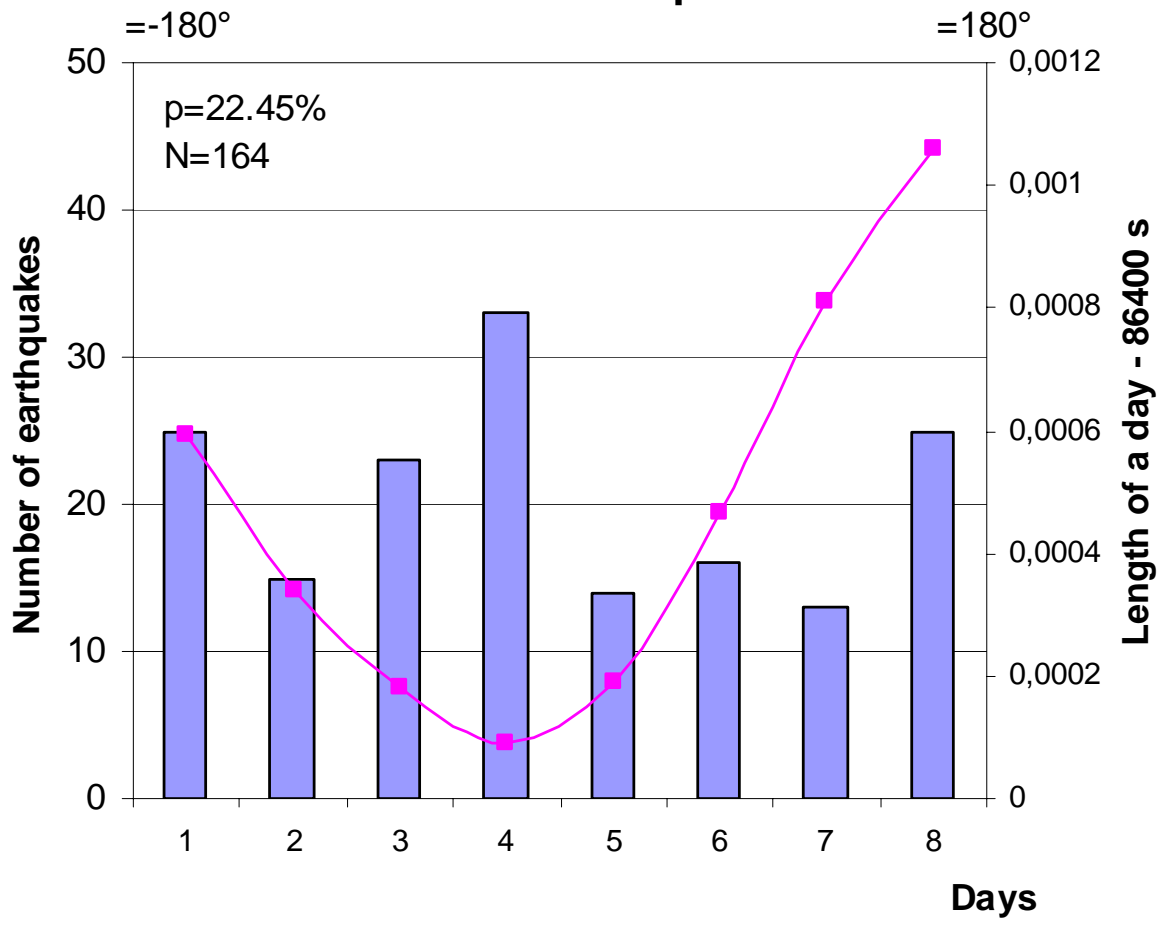

Fig. 7k3. Continued.
SED

4, 33-130, 2012

Earth's rotation variations and earthquakes 2010-2011

L. Ostřihanský

\section{Abstract}

Conclusions

Tables

14

4

Back

\section{Full Screen / Esc}

Printer-friendly Version

Interactive Discussion 
Earthquake histogram Haiti region 1976-2010 at LOD maximum peak

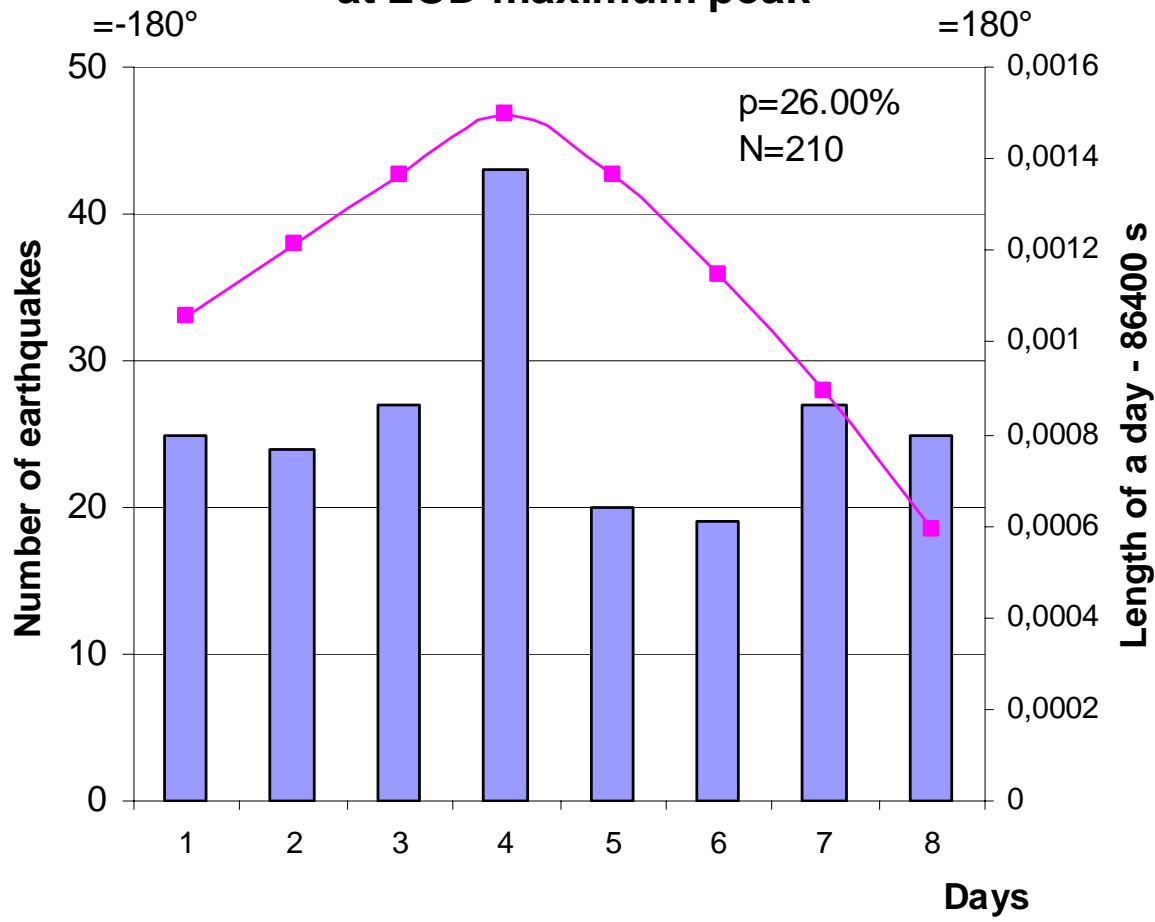

Fig. 7k4. Continued.

SED

4, 33-130, 2012

Earth's rotation variations and earthquakes 2010-2011

L. Ostřihanský

Title Page

Abstract

Conclusions

Tables

14

4

Back

Full Screen / Esc

Printer-friendly Version

Interactive Discussion 
Earthquake histogram N. Zealand 1973-2011 and in shorter time period 2000-2011

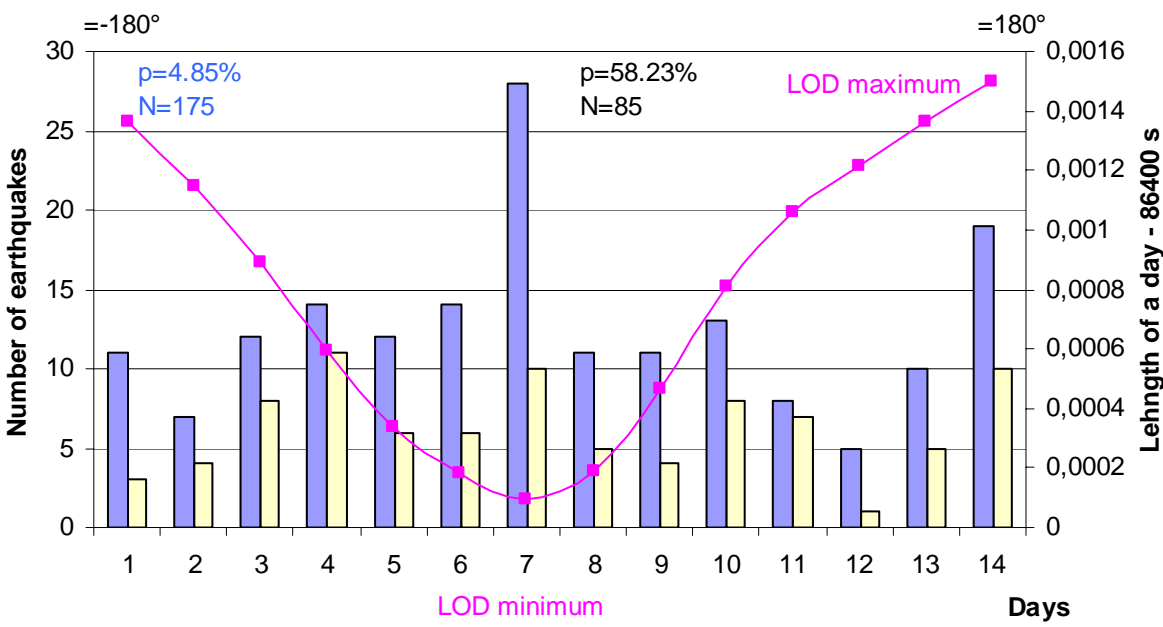

Fig. 7I. The earthquake M 7.1 Christchurch 3 September 2010 and earthquake M 6.321 February 2011 were created in LOD maximum and LOD minimum, respectively as probabilities given by earthquake histogram show. Excess of earthquakes on descending LOD branch Fig. 711 shows that similarly, as with the Southeast Indian Ocean Ridge (Fig. 7d), the Indian plate moves northward. Yellow bars mark shorter time period.

\section{Earth's rotation variations and earthquakes 2010-2011}

L. Ostřihanský

\section{Title Page}

\section{Abstract}

Conclusions

\section{Tables}

14

4

Back

\section{Introduction}

References

\section{Full Screen / Esc}

Printer-friendly Version

Interactive Discussion 
Earthquake histogram N. Zealand 1973-2011 along

\section{LOD descending branch}

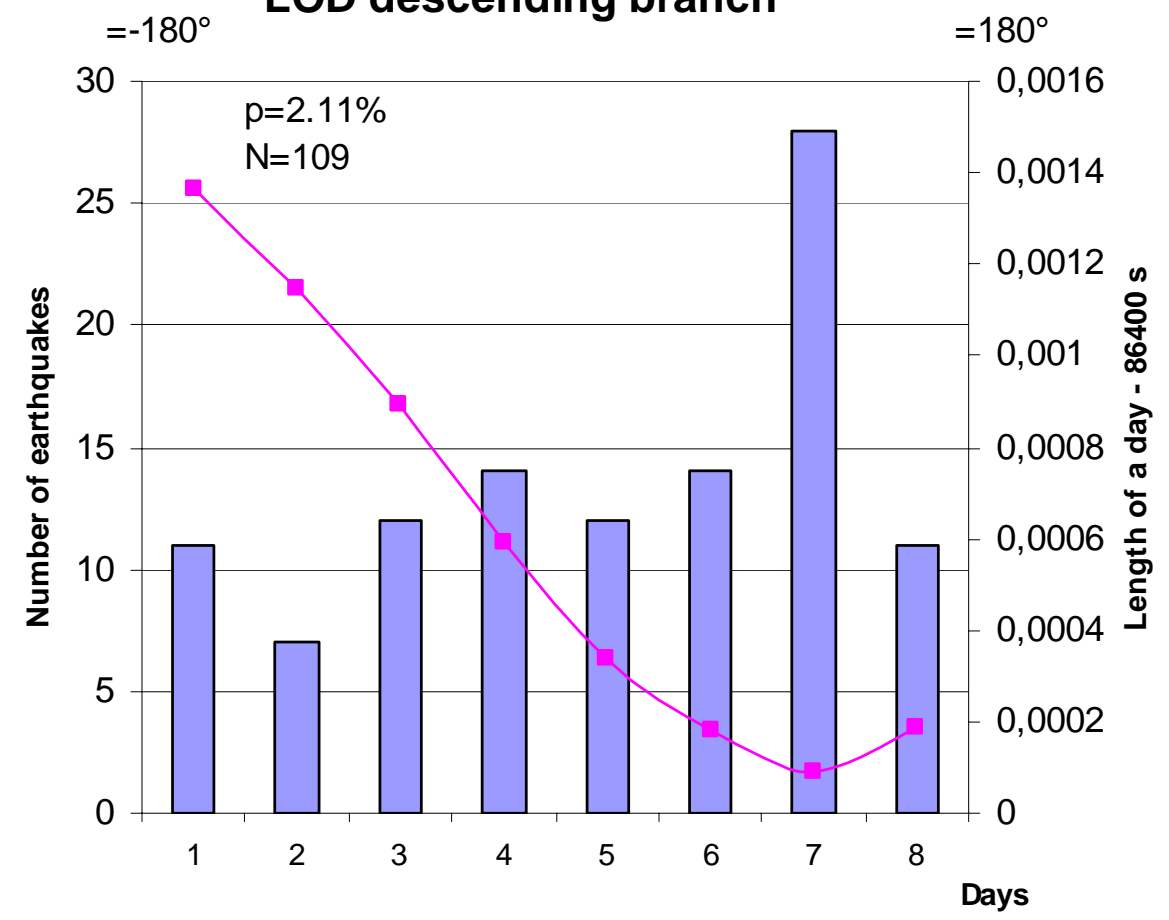

SED

4, 33-130, 2012

Earth's rotation variations and earthquakes 2010-2011

L. Ostřihanský

Title Page

Abstract

Conclusions

Tables

14

4

Back

Full Screen / Esc

Printer-friendly Version

Interactive Discussion 


\section{Earthquake histogram N. Zealand 1973-2011 along}

\section{LOD ascending branch}

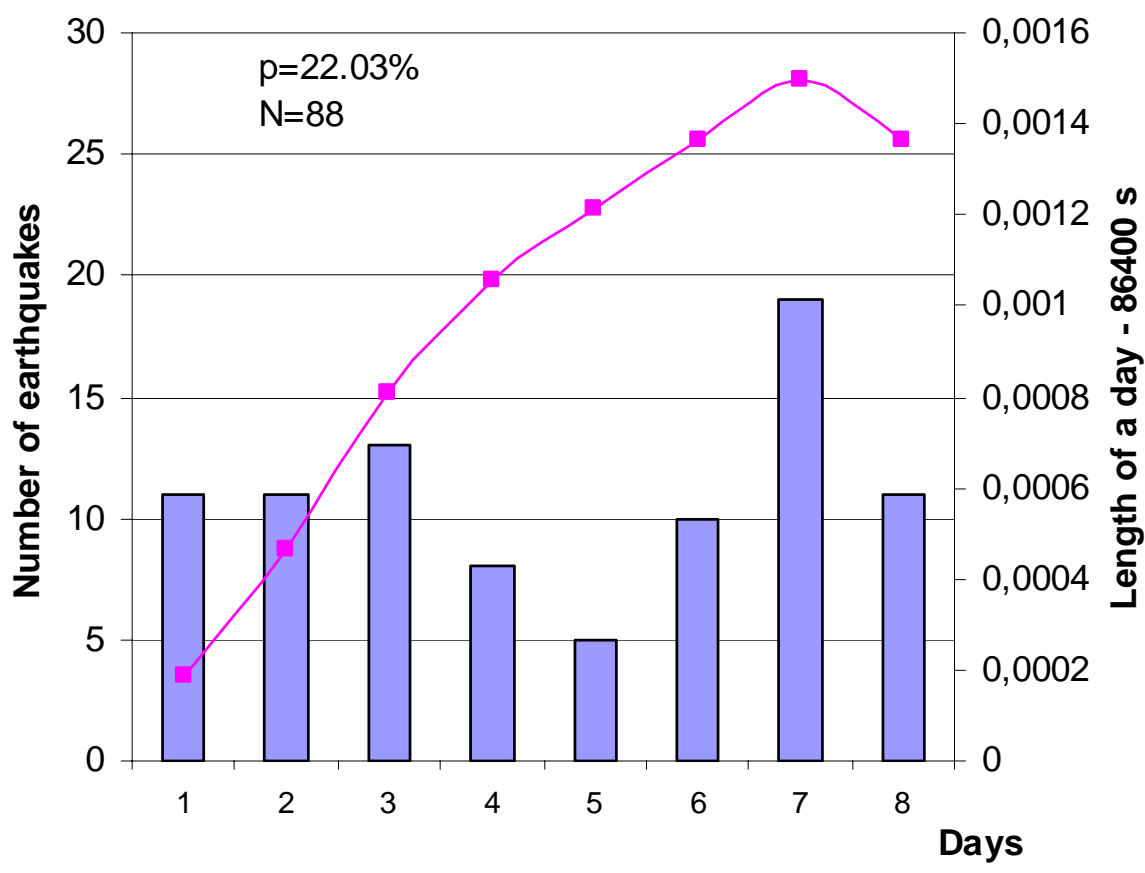

Fig. 712. Continued.

\section{SED}

4, 33-130, 2012

Earth's rotation variations and earthquakes 2010-2011

L. Ostřihanský

\section{Abstract}

Conclusions

Tables

14

4

Back

\section{Full Screen / Esc}

Printer-friendly Version

Interactive Discussion 


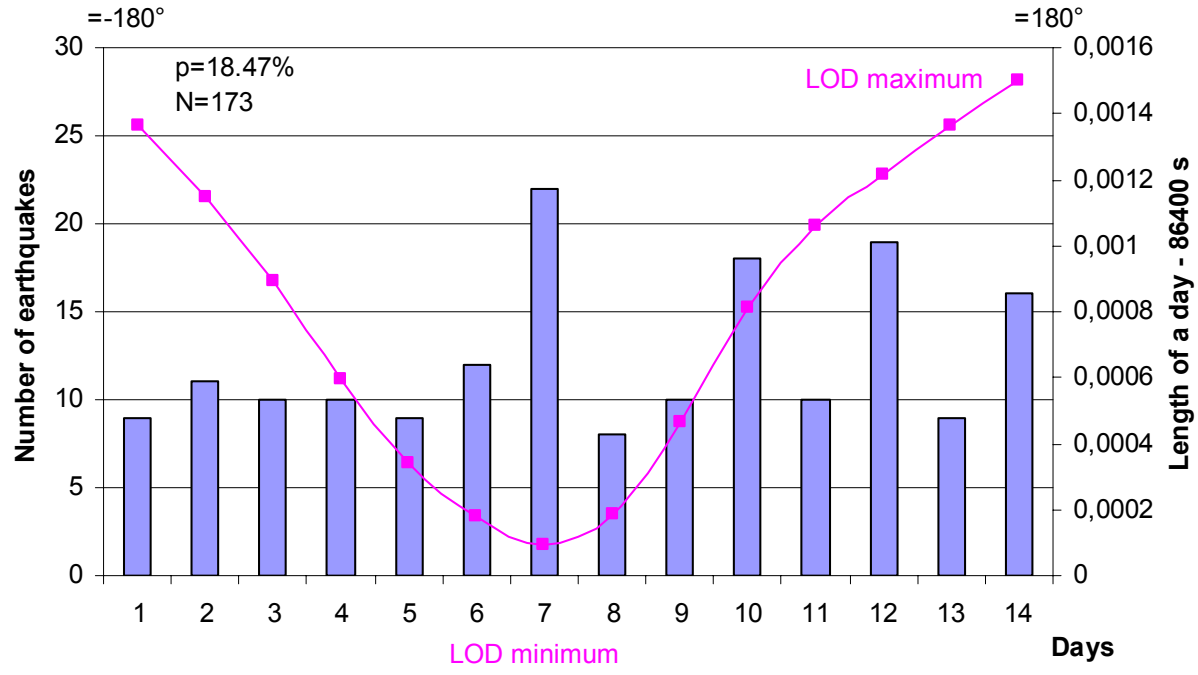

Fig. 7m. Histogram for the Japan Trench in Honshu region (Figs. 7m1, 7m2) and the Schuster's test show very low probabilities of earthquakes occurrences in LOD extremes. Nevertheless the LOD minimum shows an increase number of earthquakes. The large parameter $p=23.36 \%$ is incorrect (Fig. 7m1) owing to evidently non-random distribution. Histograms for the northern part of the Mid-Atlantic Ridge show larger number of earthquakes in LOD ascending branch (Figs $7 f, 7 f 1,7 f 2$ ). Then it is possible that also in the eastern side of the Eurasian plate the ascending LOD branch will have more earthquakes. This is the case of the Japan Trench and the earthquake of 11 March 2011 Near the east coast of Honshu M 9.0 (Fig. 5a).
4, 33-130, 2012

\section{Earth's rotation variations and earthquakes 2010-2011}

L. Ostřihanský

\section{Abstract}

Conclusions

\section{Tables}

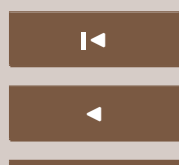

Back

\section{Introduction}

References

\section{Full Screen / Esc}

Printer-friendly Version

Interactive Discussion 
Earthquake histogram Japan Trench, Honshu region 1963-2010 on descending LOD branch

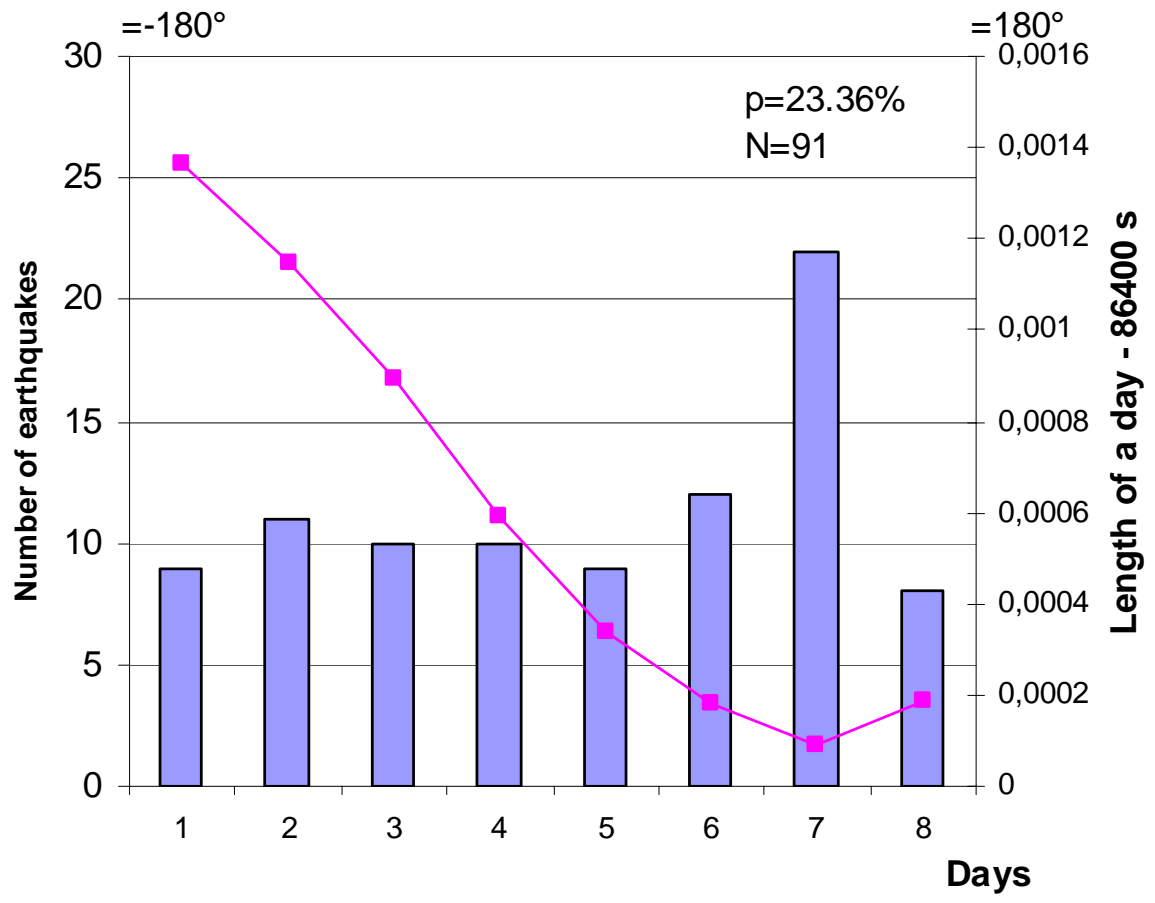

Fig. 7m1. Continued.

\section{SED}

4, 33-130, 2012

Earth's rotation variations and earthquakes 2010-2011

L. Ostřihanský

\section{Abstract}

Conclusions

Tables

14

4

Back

\section{Full Screen / Esc}

Printer-friendly Version

Interactive Discussion 
Earthquake histogram Japan Trench, Honshu region

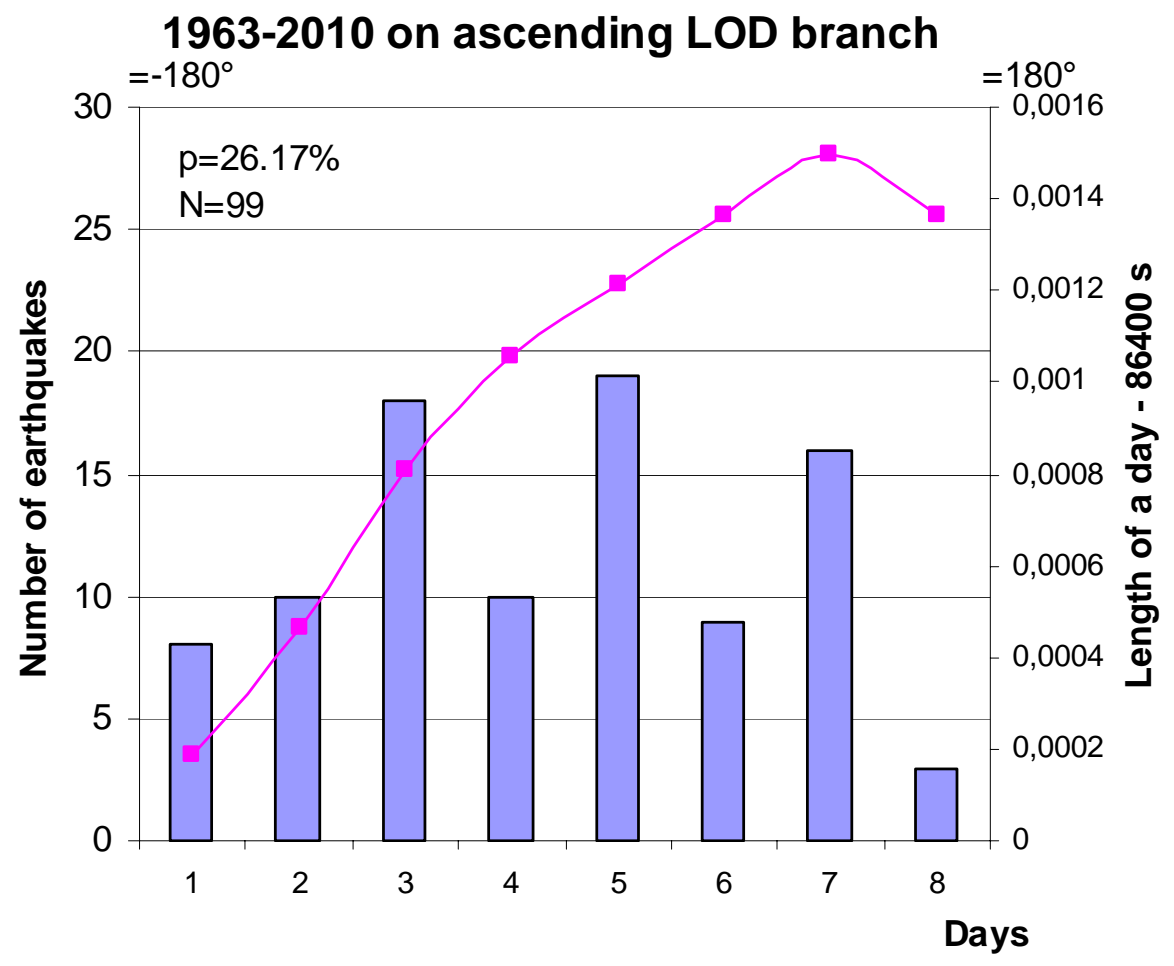

Fig. 7m2. Continued.

SED

4, 33-130, 2012

Earth's rotation variations and earthquakes 2010-2011

L. Ostřihanský

Title Page

Abstract

Conclusions

Tables

14

4

Back

Full Screen / Esc

Printer-friendly Version

Interactive Discussion 


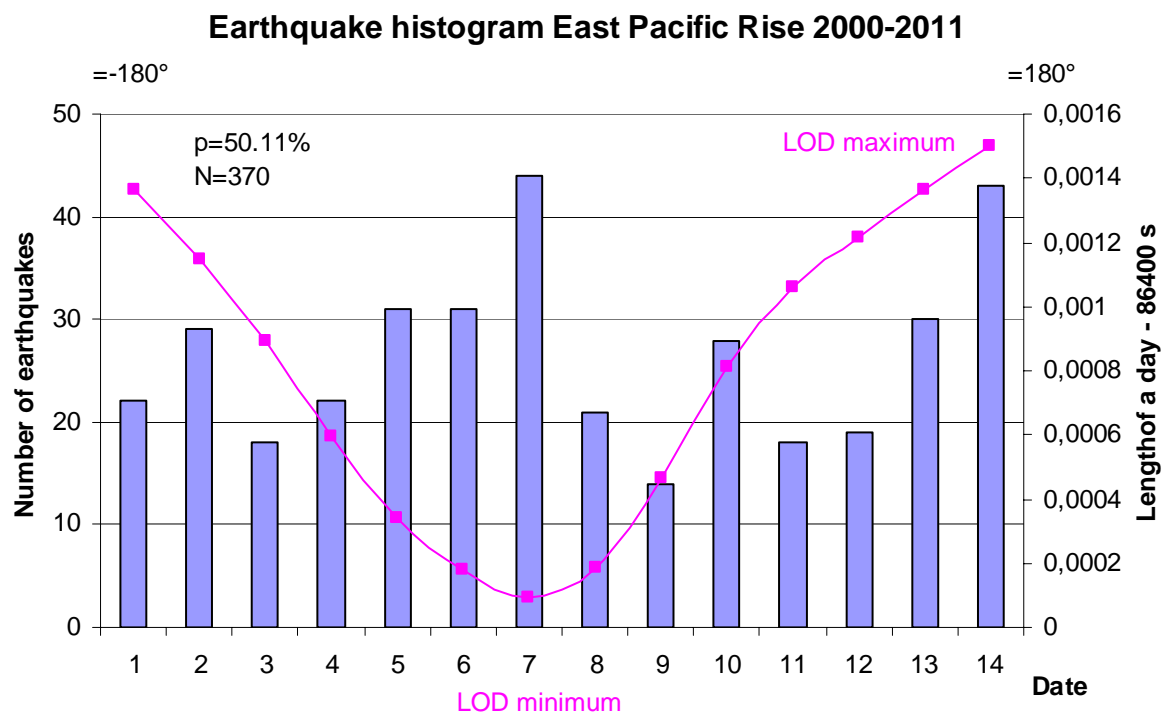

Fig. 7n. Histogram for the East Pacific Rise shows an increased number of earthquakes in LOD descending branch. This indicates that one side of the Rise moves quicker but more slowly than the western side of the Mid-Atlantic Ridge (Fig. 7j), i.e. the South American continent overrides the Nazca plate.

\section{Earth's rotation variations and earthquakes 2010-2011}

\section{Ostřihanský}

\section{Abstract}

Conclusions

\section{Tables}

I

14

4

Back

Full Screen / Esc

Printer-friendly Version

Interactive Discussion 
Earthquake histogram East Pacific Rise 2000-2011 on LOD descending branch

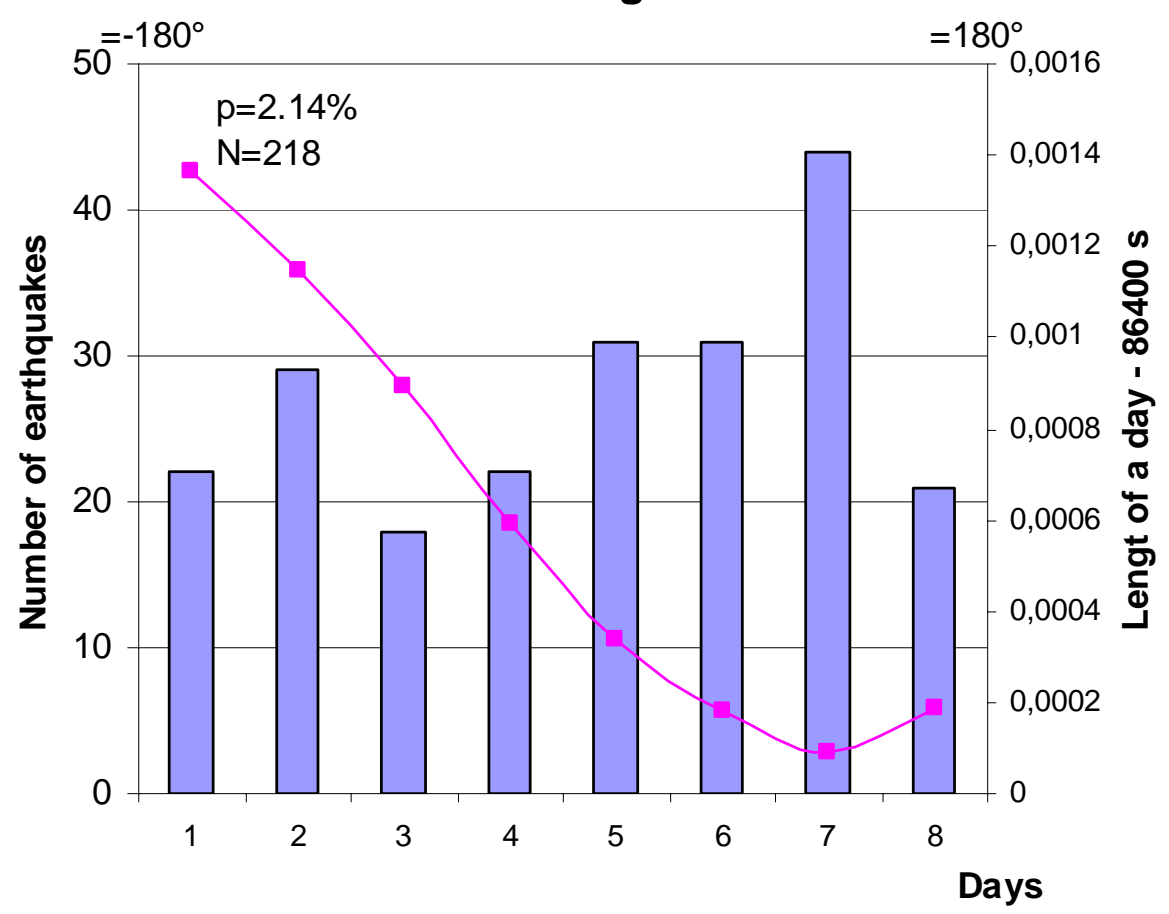

Fig. 7n1. Continued.

SED

4, 33-130, 2012

Earth's rotation variations and earthquakes 2010-2011

L. Ostřihanský

Title Page

Abstract

Conclusions

Tables

14

4

Back

Full Screen / Esc

Printer-friendly Version

Interactive Discussion 
Earthquake histogram East Pacific Rise 2000-2011 on LOD ascending branch

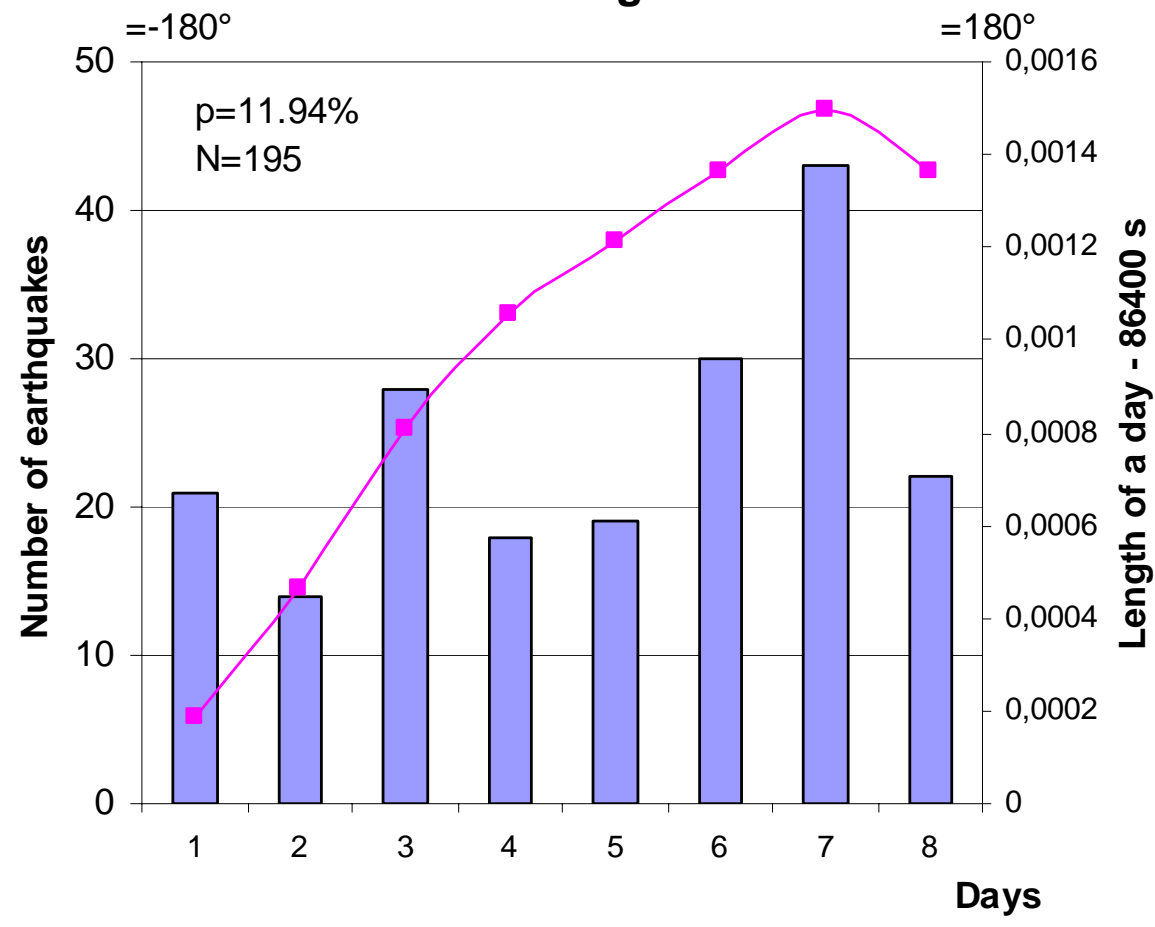

Fig. 7n2. Continued.

SED

4, 33-130, 2012

Earth's rotation variations and earthquakes 2010-2011

L. Ostřihanský

Title Page

Abstract

Conclusions

Tables

14

4

Back

Full Screen / Esc

Printer-friendly Version

Interactive Discussion 
Regular changes of earthquakes on ascending and descending branches of LOD record (V.1999-IV.2001). Northern part of Mid-Atlantic Ridge $\left(10^{\circ} \mathrm{N}-5^{\circ} \mathrm{N}\right)$

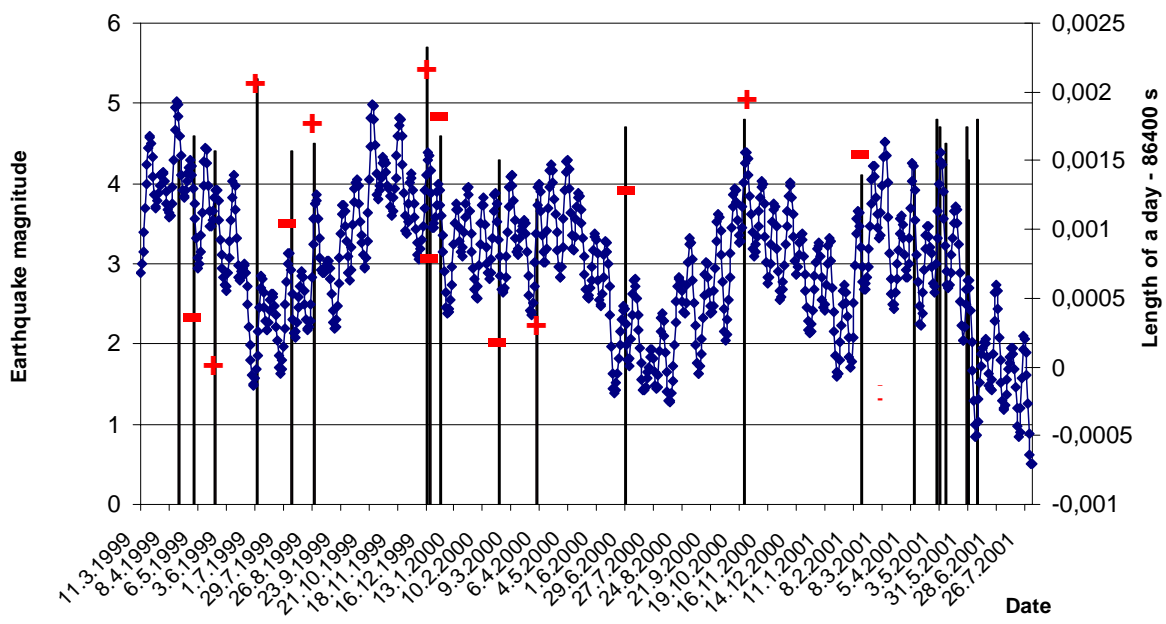

Fig. 8. Regular changes of earthquakes positions on ascending (+) and decending (-) branches of LOD record. Compare histogram Fig. $7 \mathrm{~g}$.
Earth's rotation variations and earthquakes 2010-2011

L. Ostřihanský

\section{Abstract}

Conclusions

\section{Tables}

14

Back

Full Screen / Esc

Printer-friendly Version

Interactive Discussion 